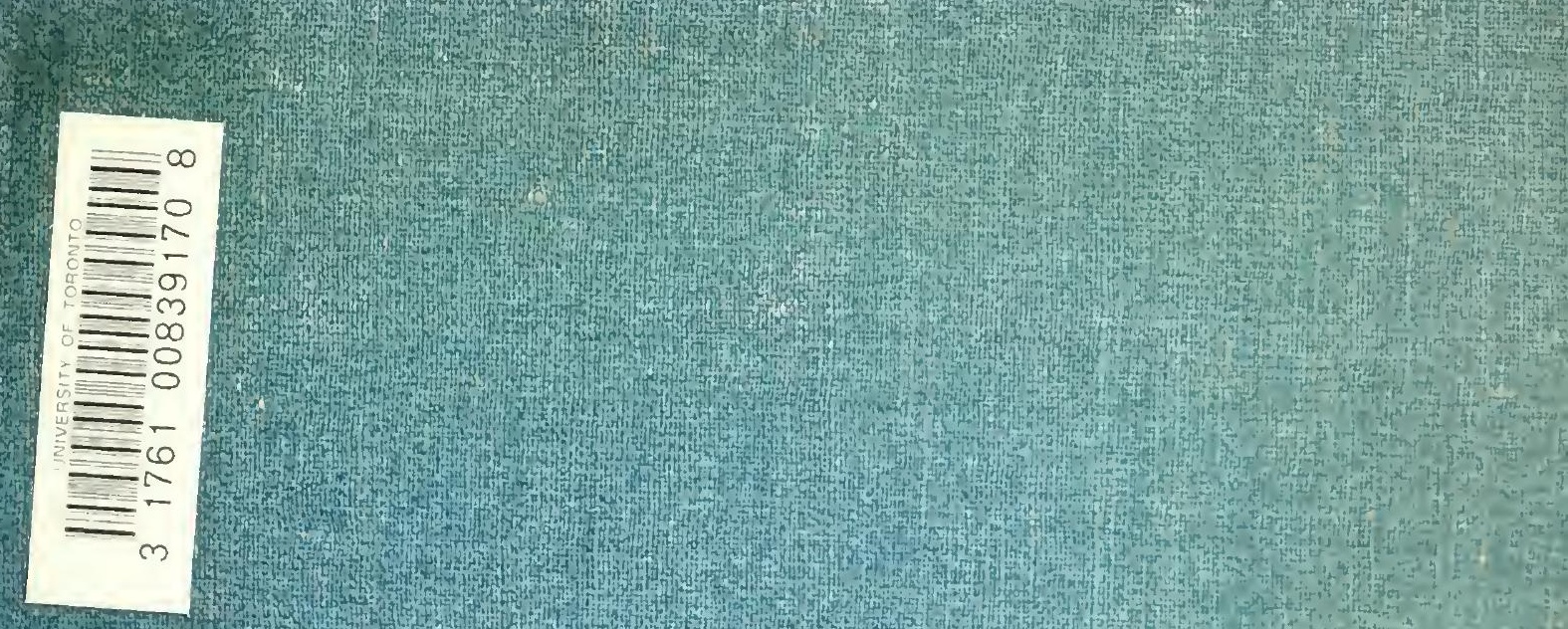

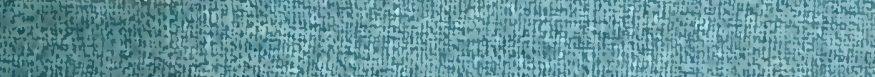

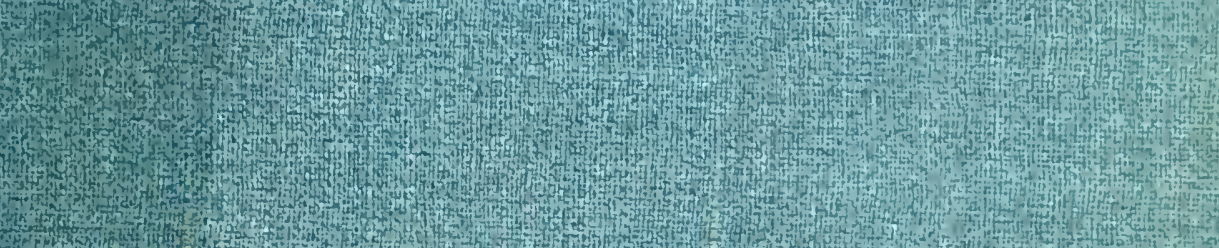

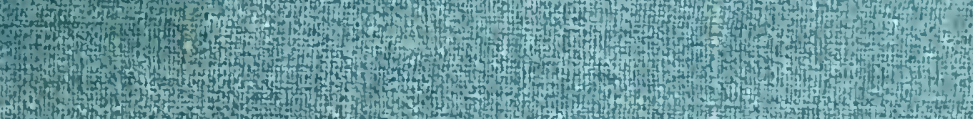

(1)

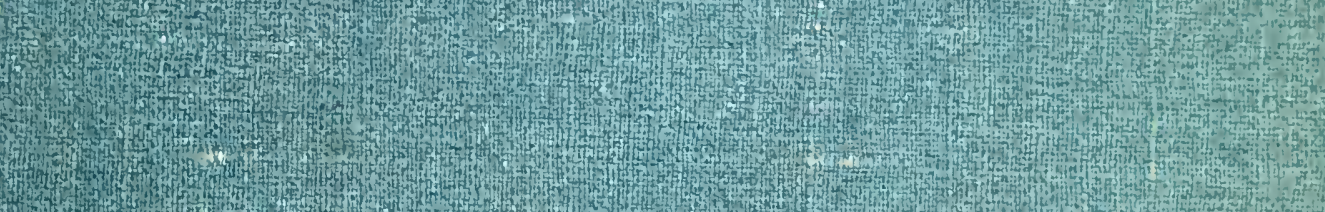

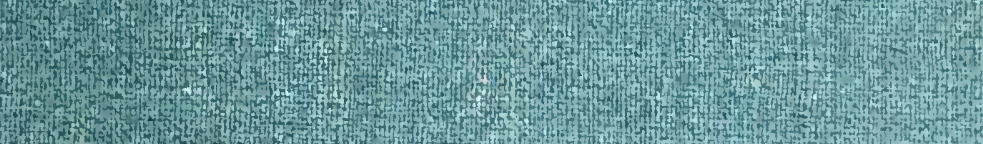

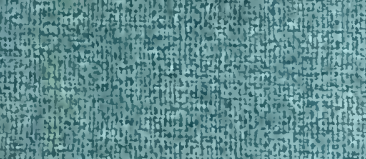

Pon

The

(1)

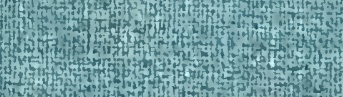

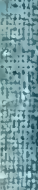

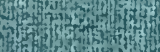

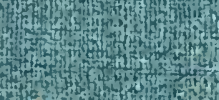

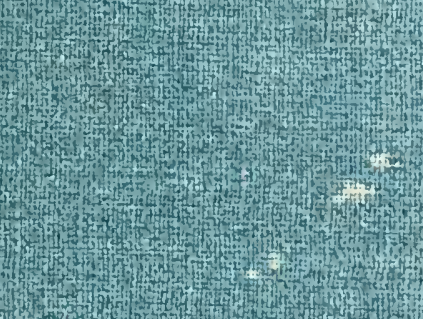

How 10

Dro

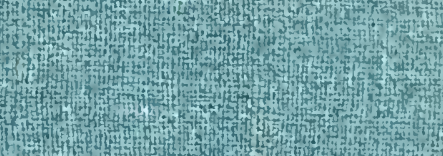

$7 y^{4}$ 


Digitized by the Internet Archive in 2008 with funding from Microsoft Corporation 

MIUTATIONS, VARIATIONS, AND RELATION-

\title{
SHIPS OF THE OENOTHERAS
}

B X

\author{
I). T. MACDOUGAL, A. M. VAIL, AND G. H. SHULL
}

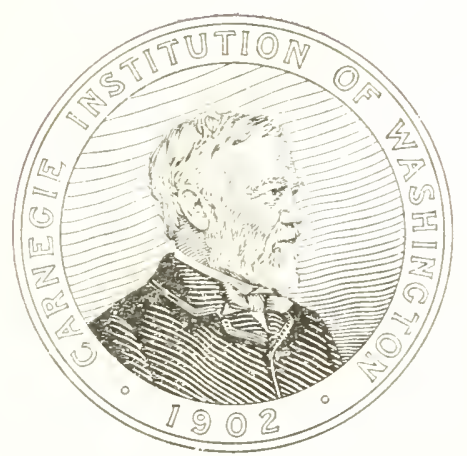

WASHINGTON, D. C.:

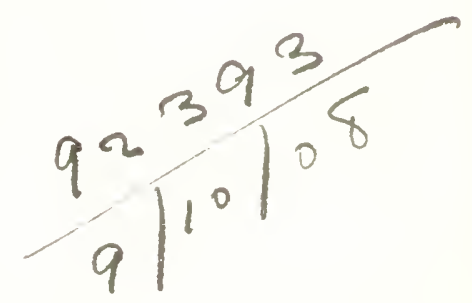

Published by the Carnegie Institution of Washington 1907 
Carnegle institution of Washington Publication No. 8 i.

Papers of the Station gor Experimental Evolution, No. 9.

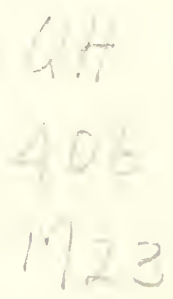




\section{MUTATIONS, VARIATIONS, AND RELATIONSHIPS OF THE OENOTHERAS.}

By D. T. MacDotgal, A. M. Vail, and G. H. Shlih.

\section{SCOPE OF INVESTIGATION.}

The oenotheras lave furnished so much evidence of inportance in connection with saltatory action in heredity that it has been deemed important to continue the cultural investigation of the group begun in 1902.

Seeds representing the species in eultivation in the principul botanical gardens of the world have been procured, and these, in addition to a larg: number of forms native to eastern Nortl America, have been grown in guarded cultures.

Attention las been paid to the occurrence of mutants in (Anotheralamarchian $z$ with a view to testing tha conffeient of mutalsility and the influence of environmental conditions on mutation. Extensive sowings have been made for the purpose of finding derivatives hitherto undetected, with a coefficient of mutability so small as to have escaped observation. Ieseriptions of known mutants have been made independently for the purpose of comparison with supposedly identical forms in Ansterdam and of facilitating observations of all kinds upon the subject.

Many important relations between mutants and their parents may be nost adrantageous.' considered by statistical methods, and the studies begun by one of the authors in 1904 thave been continued and extended to include additional mutants. The height and branching of the stens and the width and length of the leares liare been again taken into account, but owing to the great susceptibility of these organs to variation in direet response to environment, measurements have also been made upon the buds. The lesser variation of the latter in correlation with regetative characters makes them much nore satisfactory for the study of hereditary relations, and it is elear that their statistical study in connection with pedigree-cultures will demonstrate in several generations the permanence or evanescence of the mutant types and give decisive answers to such questions as the relation between fluctuation and mutation and the "fixing" of variations through self-fertilizations or their disappearance through crossings. 
Gillarded pedigree-cultures have been made from pure seeds of native species of evening primroses which had not previously been brought under close observation, with a riew to procuring additional evirlence on mulability in this gronp.

The prelininary examination mate it apparent that the group comprises a swarm of clearly separable species, many of which had not been recognized by the taxonomists and which gave basis for the current opinion as to the wide variability of the common evening-primrose $(O$. bicnnis).

The study of genetic relationships and of the phenomena of livbridization in general has necessitated the organization of extensive eultures, which will need continuance for two or more seasons before defunite results may be announced, and their discussion is reserved for a future paper.

A few cases of fixed hybrids lave been encountered, howerer, in which the crossing of two species resulted in the production of a progeny consisting of one fixed type constant in successive generations. Forms arising in this way are, in reality, new speeies, and doubtless many such have arisen naturally and now constitute a part of the native flora.

Striking eases of vegetative mutation, or bud-sports, having arisen, attention has been devoted to a study of the inheritance of the saltatory groups of characters.

A systematic attempt to localize mutatory changes in the life-cycle of the sporophyte has been made, and has met with marked sucess in a preliminary way, since it lats been possible to induce new mutants by the use of solutions of strong osmotic activity and by highly dilute preparations of mineral salts, some of which are poisonous to plants in high concentrations and stimulative in low concentrations. Finally, an attempt has been made to bring the facts disclosed in the descriptive part of the paper into correlation with prevailing theorices as to plyygeny and evolutionary procedure.

The principal results were obtained from cultural investigations in the experimental grounds and greenhouses of the New York Botanical Garden and of the Station for Tixperimental livolution at Cold Spring Harbor, I,ong Island, and were also extended in the later stages to the Desert Botanical Iaboratory of the Carnegie Institution of Washington at Tueson, Arizona, thus securing the advantages of a wide range of climate and soils.

A note regarding the various mutants was presented at the weekly botanical convention at the New York Botanical Garlen, November 1, Igo5, and a second one, dealing especially with sports or vegetative mutations, before the Torrey Botanical Club, on November 4, 1905. A lecture dealing with listorical aspects of the pluases of the subject nuder investigation was presented to the Barnard Botanical Chub, December 18 , I905, in which the first announcement was made of the induetion of mutants by chemically and osmotically active stinnti. I full lescription of the technipue of pedigree-cultures and 
of the methods employed in the stimulation of ovaries was given in a lecture at the Woods Hole Narine Biologieal Laboratory, July 20, 1906, in eonjunetion with which derivatives thus obtained of the second generation in Raimamin and of the first of $O$. bicm wis were exhibited. The restlts of Dr. Slutll's statistical inculiries were presented before the Botanical Society of Imerica at New Orleans, January 3, rgo6, and various notes have been presented before other societies.

\section{PEDIGREE-CULTURES OF OENOTHERA LAMARCKIANA}

Arrangements were made by which seeds were obtained from four separate indiriduals, purely fertilized with their own pollen. This was done by applying the pollen to the pistil of the same flower or of another flower of the same plant. All sowings were made in earthenware pans, io by , 30 em., filled with soil sterilized in an autoclave as in previous cultures, and when suffieiently dereloped the seedlings wore removed, to be transplanted or discarded, as the conditions of the experiments demanded. The eultures are given under the key-numbers by which they were designated in the journal of the experimental garden.

A. I. O.-A packet of seeds which was given the foregoing designation, which had been harvested in Amsterdam in rgor, and was obtained directy from Professor De I'ries. The sowing was made in August, 1904, and the small rosettes were inspeeted by Professor De Vries late in September, 1904. and he kindly assisted in the identification of a few of the mutants ineluded. Some confusion in the record makes it impossible to give the exaet eensus of the eulture, but it comprised between 500 and 600 seedlings, among which 26 mutant derivatives were identifiable, and, so far as possible, two representatives of each type were transplanted to the experimental garden in May, 1905 , eoning into bloom about 60 daỹs later.

The atthors have not lad the opportunity of inspecting living specimens of all of the mutants which have appeared in Amsterdam and which have been deseribed by Professor De Vries, and of the 9 forms seen but 5 have been conclusively recognized. Of these, O. oblonga was represented by 12 individuals, constituting +6 per cent of the total number of nutants. The average frequency of this type among the mutative progeny is i per cent, or 20 per cent of the mutants, although in one series De Tries found 1,6 oblongas among a total of 334 mutants derived from a culture consisting of over 14.000 individuals. In this instance oblonga constituted nearly 5.3 per cent of the mutants or r.25 per cent of the entire progeny. (In De Vries, 1905. 1). 545. the proportion of oblonga in cultures is given as ro per cent, which is a misprint for I per cent.)

In the New Tork culture under discussion, lata was represented by one individual, nanella by one, albida by two, and grgas by one. Of these, the 
appearance of qigas is the most notable, since it has occurred but few times in the last twenty years in pedigree-eultures of $O$. lamarckiana.

The remaining four forms among the mutants were represented by one, one, two, and five indiriduals. Of these, one type with orbicular leaves presented a most striking departure from the parental form, but failed to perfect flowers, so that but little information concerning it was gained. The form in question was reprseented by one individual only, and did not appear in any other eulture

It is to be noted that the seeds used in this culture had been stored for three years. Doubtless the parental type and the derivatives are characterized by varying and different powers of endurance, so that the coefficient of frequency of the several forms in question might be expected to be slightly different from that found in freshly harvested seeds.

C. 1. 2.-A lot of purely fertilized seeds derived from one individual, harrested in the New York Botanical Garden in 1903, was sown in sterilized soil in the greenhouse in Angust, 1904. In September the plantlets were so far advanced as to admit of recognition of a number of forms, and a number of duplicates of the parental type were discarded. This process was repeatcd at intervals throughout the winter, and the remaining rosettes were transplanted to the experimental garden in May, I905. Seven derivatives were seen, including 33 individuals. Among these, were 2 of scintillans, 3 of albida, is of oblonga, and 2,2,3, and 3 of four other unknown types. Some of these unknown types also occurred in other cultures, and 3 of the known and unknown were not duplicated in other progenies.

The total number of the seedlings included was probably not much above 500 , and if this were conclusively confirmed it would furnish an illustration of a progeny in which the mutants constituted about 6 per cent of the entire number. Unfortunately some confusion was found in the record. Before this was discovered, the senior author announced that he had succeeded in modifying the coefficient of mutability, but, as is to be seen from the above, the evidence is not conclusive. The large proportion of oblonga is noticeable, and this form constitutes $5+$ per cent of the total number of the mutants.

D. 1. 7.- - t lot of purely fertilized seeds taken from one individual, grown in the New York Botanical Carden in 1904, was sown in the garden in August, 1004 . furnishing a total of 499 plantlets. Development proceeded so rapidy. that it was possible to select and discard 244 duplicates of the parental type on December t, 1904. The remaining ones were transferred to small pots. Forty-three more cluplicates were disearded on February 9, 1005,34 on February i 8, fo on March 3,6 on March 2 I, 2 on March 24, 3 on March 27,7 on March 30 , and 1 on April 17 . On May 15, 19 mutants and 2 of the parental type were transplanted to the experimental garden. The detail given above illustrates the general procedure in all such cultures. 
As a restilt of the continued inspection of the culture it was seen to include 3 of nanclla, 2 of lata, 6 of albida, and 3 of oblonga, while the remainder could not be identified. One was purely pollinated to test its relationship with giqas. The coefficient of mutability in this culture was seen to be barely 3 per cent, and the proportion of oblonga was much lower than in any other culture.

D. 1. 9.-A lot of purely fertilized seeds designated as above, harvested in the New York Botanical Garden in August, 1904, was sown in two earthenware pans filled with sterilized soil, early in November, 1904; 604 plantlets were produced; 390 duplicates of the parental type were discarded on Decenber + th, I 904 , and 66 on December 15 th; 77 were transplanted for further inspection on December 21 st, and the renaining $; 1$ on January 15 th, 1905; of these, 59 were discarded on February 9 th, 3.3 on February 18 th, 15 on March 3 d, 3 on March 21 st, 5 on March 24 th, and 4 on March 30 th; 19 mutant individuals were transplanted to the experimental garden on May i6th, 1905, of which I was nanclla, 2 were lata, 2 scintillans, 1 albida, and 2 oblongh, and the remainder were of types not identified by the autlors.

The coefficient of nututability in this instance is seen to be about. 3 per cent, and that of oblonga very small in comparison with the general frequeney of this derivative.

\section{IDENTITY AND DISTRIBUTION OF OENOTHERA LAMARCKIANA.}

Since the cultures of the evening-primroses was begun, a few years since, no opportunity has been neglected to attempt to trace (1). lamarkiana to its original habitat and to establish its relationship to other species of the gents. Among numerous bibliographical discussions of interest in this connection, one by Miller $(1 ; 60)$ is of great interest. He says regarding the "'Tree Primrose with oval spear-shaped indented Leaves, and Flowers proceeding from the wings of the Leaves on the Upper Part of the Stalk:"

This plant is also a Native of North Anerica; but was the first species of the Crenus which was brought to Europe, so it is more commonly seen in the Gardens than any of the other species. In some parts of Europe, this is spread about from the Gardens in such plenty, that it might be supposed a native there. In a small wood near Harlen in Holland, this plant covered the ground insomuch that many skilful persons supposed it was a native of that place. But it may be easily accounted for, because the gardeners who live near that place are chiefly lorists, and they annually change the earth of the beds in their gardens; so by carrying out of their old earth from their beds, in which many of the sceds were scattered, the plants cane up there; and those being suffered to scatter their seeds, had filled the whole wood with the plants.

This differs from the first sort (described and ficured as C. biennis) in liaving broader leaves; the stalk grows taller, and he flowcrs are much larger. Both these sorts will thrive in the Smoak of London better than most plants.

The appended descriptions and the plate (No. IS9, dated 175\%) very fittingly characterize O. bicnnis and O. lamarckima, and as the descriptions were 
made before $O$. grandiflora, the only known species which might be confused with $O$. lamarckiana, was discovered, the inference may be drawn by exclusion that nothing but $O$. lamarckiana was referred to, and this inference is strengthened by the fact that $O$. lamarckiana was recognized and cultivated in the Paris gardens a few years later.

Of the cultures that have been carried out from material obtained from various sources, the following are seleeted as of unusual interest:

Two sheets of dried material of O. lamarckiana, collected by Mr. E. P. Bicknell at Nantucket City, were received in September, 1904. These plants had been found in the previous month, growing near a cottage, and had spread to an adjoining waste lot. A visit was made to the place in August, 1905, by the senior author, but no trace of the plant could be seen, although it was found again in 1906 by Mr. Bicknell. This journey was inspired by the behavior of the seeds taken from the herbarium specimen and sown in sterilized soil in November, 1904. No particular attention was paid to the lot, but on January 27, 1904, 24 plantlets representing the widest diversity observable were transplanted to small potsin accordance with the usual practice. Six of these corresponded quite exactly to the mutant $O$. albida. Four of these died before May, 1905, at which time the remainder were transplanted to the experimental grounds. All of the other individuals developed in accordance with qualities of $O$. lamarckiana, with a maximum amount of color in the buds, and also a maximum number of basal branches of some length. The pale mutants, howerer, did not proceed beyond the rosette stage in 1905 .

The owner of the grounds in which the original plants were growing in Nantucket could not give any information as to the origin of the culture, except to say that it had been started from seeds a great many years before.

A lot of seeds taken from a trade packet sold by Vilmorin \& Company, of Paris, were sown in sterilized soil on January 3,1905 . The record shows that 192 duplicates of the parental type had been discarded when the I 1 remaining ones were transplanted to the experimental garden on May 16 . Of these but 3 were mutants, including I lata, I namella, and I albida. The mutants were thus seen to constitute but I.5 per cent of the total eulture.

Far the most interesting material and records were obtained from England, and it was found that $O$. lamarcliana has been growing in some profusion in certain localities in that country for several years.

In 1905 Mr. H. Stuart Thompson (Thompson, 1905) called attention to Conothera biemis L. and O. odorata Jaeq., growing on sandlitls in Lancashire and Somersetshire, and with the view of comparing the native North American O. bicnnis with the plant so ealled growing in England, Mr. C. Theodore Green was applied to for seeds of the plant growing in Iiverpool district. To him, therefore, we are indebted for seeds, a photograph of the Lancashire O. bicnnis, and the note on the following page (Green, 1902). 


\section{OENOTHERA "BIENNIS" LINNAUUS.}

Form as found on both sides of the River Mersey, from the estuary of the River Dee to Southport, 18 miles north of I.iverpool. It is especially luxuriant about Formby Sandhills, 9 miles north of Liverpool, and about Bidston railway junction, 3 miles north of Birkenhead. It flourishes in sandy waste ground, chiefly among the hills of blown sand along the coast, and extends a few miles inland in scattered groups of plants. It also is found frequently in cultivated ground in cottage and other gardens from the Dee to Southport. I do not know the date of its first appearance in the I.iverpool district, but it was mentirned in Dickinson's Flora of I,iverpool publication, $185 \mathrm{I}$ and 1855 .

F. W. Webb saw it near Leasowe (1860), 5 miles southwest of Liverpool, and T. Sanson at New Brighton (Dick, Flora).

I have known it in various parts of this peninsula of Wirral (between Mersey and Dee) since 1892 .

It has in the last five years extended greatly about Bidston Junction among the sand. There is much more of it north of Liverpool. In C. C. Babington's Flora it is given as "American" and its home "Lancashire Sandhills." When newly opened the flowers are very fragrant, but only last twenty-four hours.

Seeds inclosed, more of which I can send if desired; came from Bidston Junction. This plant is identical with that of North Liverpool.

At Bidston, the characteristic sandhill plants anong which it flourishes are Ery'simum cheiranthiodes, Brassica monensis, Anthyllis zulneraria, Psamma arcnaria, Equisctum maximum, Lychnis alba, Senccio jacobaca, Salix arcnaria.

It extends chicfly along the railway lines, which is sugrestive as to its origin.

Inclosect enlargenent from one-fourth plate shows the plant in sitn, with flowers and fruit stems in end, September, 1905. This year I saw the same type of this plant about the railway at Llangollen in the northwest.

Mr. H. Stuart Thompson ('Thompson, I906) quotes Watson's New Botanist's Guide $\left(18_{37}\right)$ as the first record of $O$. biemmis on the coast of Somerset and says, "indeed it is quite a feature in the landscape." It was this sentence that aroused interest in these special plants, as anyone conversant with the weed-like aspect of the $O$. biennis of this region would searcely credit them with anything like a spectacular appearance.

Hall in 1845 (Hall, I 845, p. 37) speaks of the plant as being extensively naturalized on the Liverpool sandhills, and James Edward Smith in 1 So6 (Smith, I 806, p. I 534) figures a plant that was gathered on the extensive and dreary sandbanks on the coast a few miles north of Liverpool, where millions of the same species have been observed by Dr. Bostock and Mr. John Shepherd, perfeetly wild, covering a large tract between the first and second range of sandhills. Some natural cause has no doubt established it here, though possibly from the opposite side of the Atlantic. The Smith plate and the plant figured by Baxter (Baxter, I839, p. 257) certainly do not represent the common North American O. biennis, and the elosing note in Baxter, referring to the sudden expansion of the flowers, applies more readily to such largeflowered species as O.grandiflora, O.lamarckiana, and O. argillicola than to the smaller-flowered ones, like $O$. biennis, $O$. muricata, and $O$. oakesiana. 
A recent writer on the flora of Iancashire records that $O$. biennis has been established there for the last 70 or 80 years and that "whenever the land is disturbed, or the sand removed to form new roads, this plant is one of the carliest to grow upon it, and although its conspicuous flowers make it an easy prey for constant plucking, it survires these depredations and continues to spread more and more."

IVith Mr. Green's photograph and these references in mind, it was with no little curiosity that the cultures from his seeds were watched. The seedlings raised from them early in 1906 proved to be indubitable O. lumarckiana. In the seed-pan 2 seedlings of $O$. lata and 4 seedlings of $O$. mbrinervis were also recognized among a preponderating number of the O. lamarckiana. These plants were observed unto maturity. O. mbrinervis displayed all the characters ascribed to it by Professor De Vries, with the exception that they were not quite as large as some that had previously been studied in the New York Botanical Garden. The two plants of $O$. lata, on the contrary, were more robust than any we had had in New York from Professor De Vries's seed, and the pollen being more abundant than is usual in the species, efforts were made to self-pollinate the flowers in the attempt to obtain pure seed. In due time a few capsules ripened, containing a very small amount of seed, from which were raised in December, 1906, 8 O. lamarckiana, Io O. lata, 2 O. oblonga, and 1 O. albilla seedlings.

Before these facts were ascertained, the presumption was that the British O. biennis was a slightly larger-flowered evening-primrose, and in our cultures from foreign seed we usually named it "European biennis," of which no real equivalent appears to be known here. Whether onr native smallflowered species is also known in Creat Britain is not apparent from the manuals, as the species there recorded indicates a nore ornamental plant than the one with which we are familiar here, and ours is certainly not "adapted to the shrubbery."

The misunderstanding in regard to the identity and provenience of $O$. bicnnis, O. lamarckiana, and (). muricata seems to be widespread. There is now no doubt as to the identity and original habitat of O. grandiflora Aiton. The time and manner of its introduction into England are also known. It escaped from gardens after it was taken into England in 1778 , and is now found growing wild in many places, according to unverified reports.

But as to the advent of lamarckiana we are still at a loss for positive proof. 'The plant referred to by Miller, if correctly identified with this form, would place it in Haarlem in 1757, 21 years before the discovery of grandiflora. The next we hear of the grandiflora of Lanuarck is in the Paris garden in 1797 , which was seen by Seringe not to be the grandiflora of Aiton as known in Fingland and was renamed after its illustrious discoverer. Next we have the striking form which is described above as appearing on the coast of Somerset 
in $I$ S 37 , and at other places since then, forming now quite a feature of the Liverpool sandhills, which has been shown by our cultures to be the lamarckiana around which so much interest chusters. It would seem difficult in the light of these facts to find any basis upon which the conclusion that this plant had been derived from (). aranliflora might rest.

The plant originally introduced into Europe under the name of o. biennis seems to have been a large-flowered form altogether different from the plant under that name as known in America. Then (). lamarckina grown from imported seeds or their progeny, and (). grandiflor from Alabama, present a very different aspect and have but little resenblance to the (') biem is of the waste lands of eastern Anterica.

\section{THE MUTABILITY OF OENOTHERA LAMARCKIANA.}

About 2500 plantlets of O. lamarckian derived from rarious sources liare been brought under observation, as described above. Of these 106 or a little over + per cent were mutants. One culture (C.1.2) appeared to give a much higher proportion of mutants, but a failure to make a record of one lot of discarded plants makes it impossible to confirm this. The behavior of this lot of plants and also the eonfusion of fasciated specimens of (). lamarckiana, in the rosette stage, with nutants, led the senior author to assert that the proportion of mutant derivatives in pedigreed cultures of (1) lamarkinna had been increased from $;$ to 6 per cent of the progeny (MacDougal, 1905). In no culture of later clate has it been possible toexceed the maximum proportion of 5 per cent, and the greater majority fall much below this figure. While the coefficient of mutability has not been modified yet, one or two forms have appeared which were not recognizable in a rosette stage by Professor I)e Tries, and probably constitute an extension of the range of mutability. This, however, may not be interpreted to mean an effect of local conditions. All of the mutants now known did not occur in the cultures in Ansterdam during the first few years of the cultures. Many, in fact, occur so rarely that by the law of probability it is necessary to grow many thousands of specimens in order to secure one individual of the rare type. In accordance with this same principle it is to be seen that the spreading of the cultures of 0 . lamurckianu may be expected to bring to light other rarer derivatives. When such forms are found it is not to be interpreted as a result of local conditions of the culture in which they appear, but simply in accordance with the coefficient of mutability of the parental type with respect to the form in question.

The uniformly low frequency of mutants in material procured from seedsmen is a matter not altogether understood. Among the probabilities to be taken into account is that the seeds may have lain in storage for more than one season before being planted, in consequence of which the unequal hardiness of the mutants and the parent might operate to decrease the apparent 
frequency of the derivatives. No proof has been produced to show that the frequency of mutations might be increased beyond the limit of 5 per cent found by De Vries, but it is a well-known fact that mutations of all kinds may be decreased by inadequate nutrition, and it is quite possible that the parental plants grown to furnish seeds did not have the care and nourishment of pedigreed individuals used in the cultures. The appearance of the rare rubrinervis in the culture might be due to a hybridization with that form, since no evidence has been offered to show that the fertilizations were guarded.

The five cultures described together furnished albida, nanella, oblonga, lata, gigas, scintillans, and nine other forms not positively identifiable at this time. Seeds have been preserved, however, and it is hoped we may be able to present descriptions of at least some of the forms at the close of another year.

Since these cultures were carried through, De Vries has published the results of his cultures from seeds obtained from seed merchants. 2000 plantlets from seeds obtained from Haage \& Schmidt of Erfurt contained I specimen of rubrincris, which arises but rarely in any culture, I of oblonga, and 3 of nanella.

Two cultures were made from seeds furnished by Vilmorin and grown in 1898-1899. The first gave 14 nanella, 3 lata, 3 scintillans, I albida, I oblonga, and a few other divergent forms in 3500 seedlings. A second test yielded 3 lata, I nanclla, and I rubrinervis (?) in 600 seedlings. In both cases the proportion of the mutants was not above 5 per cent, and was even less than that described above (De Vries, 1905).

In view of the numerous observations described above upon material from the most widely separated sources, which show mutability, suggestions that the mutability of Lamarck's evening-primrose has been consequent upon its segregation in the Amsterdam Botanical Garden may no longer be taken seriously, although no doubt the well-worn phrase will be duly rehearsed from time to time by careless critics. O. lamarckiana may be of hybrid origin, and what species may not be; but if so this origin is not recent, nor can sufficient time be found to hunt down all of the unprofitable alternatives that are offered for consideration.

Exact records have already been made of lamarckian, rubrinervis, naneila, and gigas in previous papers (MacDougal, Vail, Shull \& Small, I903 and I904), and below are the principal taxonomic characters of albida, oblonga, scintillans, brevistylis, and lata, by which systematic descriptions of 9 of the 15 mutant derivatives iteratively vielded by lamarckiana are afforded from material grown in New York (see plate 1).

Notw. - The illustrations of O. lamarckiana and O. rubrinerits previonsly published by MacDougal (1903) were reduced withont proper indication of the scale.

The capsule of $O$. gigas is incorrectly given in another paper as $2 \mathrm{~mm}$. in length when it sliould he 2 cni. (MacDougal, Vail, Shull \& Small, 1905.) 
OENOTHERA SCINTILLANS.

O. scintillans was first seen to originate as a 1nutant in 1888 and has appeared in this manner in it indiriduals at different times in De V'ries's cultures. As previously described in this paper, it has appeared in + specinens in the New Tork Botanical Garden during the present year.

(). scintillums is to be noted as an erer-sporting form which in some strains gives a progeny 6oor 70 per cent of which is composed of lata, oblongu, limurckima, and nanclla, while in other strains but, 30 per cent will be included in these forms. The forms thus derived from scintillans are in no wise different in their hereditary qualities from the same types derived from other and pure lineages. Cultures were made from seeds furnished by Professor De Vries from a strain which was supposed to yield 60 to $;$, per cent of the other types named.

Seventy-eight individuats were obtained from the culture, 15 of which resenbled scintillans, 46 lammekinna, 16 oblonga, and 1 was present which dicl not reach maturity, but suggested some of the incomplete forms mentioned in "I) ie Mutationstheorie," probably inblinearis. In the seedlings 3 months old, the rosettes were $1+$ to $17 \mathrm{~cm}$. in clianeter, dense, and spreading tlat on the gronnd: outer leaves, 6 to $7 \mathrm{~cm}$. long. Dlades about $5 \mathrm{~cm}$. long, 2.5 to 3 cin. wide, oblong-obovate, widlest about the niddlle, obtuse or acutish at the apex, tapering gradually to the white-margined petiole, blue-green, shining, puberulent, with occasional small red spots above, glabrous or nearly so, and lighter green beneath, somewhat brittle. At 6 montlis of age the rosettes were dense, the leaves lanceolate, obscurely and minntely denticulate, green and shining, puberulent on margin and sparingly on upper surface, miclvein broad, petioles variously winged.

The adult plant was short, with few branches which were fairly rigrid and ascending. The lower part of the stem appeared to be terete or nearly so, while the upper portion was angled and channeled. The stem and branches were hirsute with spreading hairs.

The stem leares were finely pubescent on both surfaces and much crinkled on the margins and nilibibs; irregularly toothed, oblong, ; to $9 \mathrm{~cm}$. long, io to $35 \mathrm{~mm}$. wide, abruptly tapering at base, acutish at the apex. The petioles were short and the entire organ was a deep shining green.

Conic portion of the bud is to $20 \mathrm{~mm}$. long, finely pubescent, with short, spreading hairs. Free tips $5 \mathrm{~mm}$. long, ereet. Hypanthium $30 \mathrm{~mm}$. long, and reflexed calyx-lobes $25 \mathrm{~cm}$. long. Oxary 6 to $; \mathrm{mm}$. long.

The petals are thin, $25 \mathrm{~mm}$. long and $30 \mathrm{~mm}$, in width, barely emarginate. Filaments is to is mm. long, very slender and strongly upcurved. Anthers ; to $8 \mathrm{~mm}$. long. Pistils slightly longer than the stanens; lobes of the stigma very slender, t to $5 \mathrm{~mm}$. long (plate 2 ). 


\section{OENOTHERA BREIISTYLIS.}

A culture was made from seed harvested by De Vries in Amsterdam in I 899 and said by him to contain about 25 per cent brevistylis, the seed being the product of the first generation of a cross between $O$. lamarckiana and $O$. brevistylis. Twenty-one plantlets appeared and were inspected, and some seemed to form rosettes with much more rounded and abruptly pointed apices than O. lamarckiana. This was the only distinction that could be made between the parental type and the derivative, during what would naturally be the first year of development. In addition one example of $O$. nanella as a mutant from the parental type was included. With the beginning of the formation of lengthened internodes in the stem but little difference between the plants was discernible until flower-buds appeared. At that time the leaves on the terminal portions of the branches and the bracts seemed relatively much broader, and the flower-buds might be distinguished at some distance by the fact that they were more cylindrical than the parental type, and were abruptly short-pointed. An examination of the structure of the flower revealed the fact that the style is much shorter than in O. lamarckiana and that the stigma generally appears in the throat of the flower and sometimes is not to be seen without tearing the hypanthitm apart.

It has been noted by De Tries that the length of the style varies widely (as much as I cm.), and in this is offered an example confirmatory of results communicated by the authors in a recent paper (NacDougal, Vail, Shull \& Small, 1905), in which the mutant characters were found to offer a wider aniplitude of variability than the correspondent characters of the parental type. In addition to the above general characters, it is to be noted that, as a consequence of the extreme shortness of the style, pollination fails in many cases and comparatively few capsules are matured.

The evidence offered by this plant is of the greatest interest in connection witl questions concerning the survival of mutants in the habitat of the parental form, especially in view of the intemperate indulgence which many authors show in theoretical discussions upon questions of this character.

O. brezistylis was discovered August 20, 1886 , by De Tries, as represented 1) $y_{2}$ individuals. Despite the greatest care and the most rigid inspection it has never been observed to arise in any of the cultures in Amsterdam or New York, and the supposition is certainly allowable that it is no longer included among the mutants giren off by the parental type. The characteristic qualities of (). brevistylis are recessive when hybridized with O. lamarckiana, and consequently the first generation resembles $O$. lamarckiana in outward form but carries 0 . brcistylis, which reappears in the next or the second generation of the liybrid, forming on an average one-fourth of the progeny, according to the simple Mendelian formula. O. brevistylis is a retrogressive departure from 
the parental type, matures comparatively few seeds, and is dominated by the parental characteristics in crossing, and it has survived in its original habitat and blooming specimens have been observed there for twenty years in competition with the parental form.

The more important anatomical features of O. brezistylis were described by Pohl (1895), but it seems desirable that its general taxonomic aspect, as presented in the cultures in New York, should be put on record.

The rosettes are open, leares ovate-spatulate, crinkled, the upper ones approximately danticulats, bright, dark grean, pubsulent beneath, less so above, conspicuous broad reins, petiole winged to near the base, nutuch more obtuse and rounded at apex than O. lamirkimur.

The adult shoot resembles 0 . lamirckin r very closely, even in the form of the stem leaves. The bracts, however, seen slightly thinner and appear somewhat broader than those of the parental type.

'The conic parts of the buds are 2 to $5 \mathrm{~cm}$. long, appearing more cylindrical than the parental form, and are covered with very short, spreading hairs. The buds are distinctly tinged with red, and the free erect tips are unectial and are not spreading.

The petals are 45 to $50 \mathrm{~mm}$. long and to $\mathrm{mm}$. wide, being firm and more or less deeply emarginate. The filaments are $2 \mathrm{~cm}$. long, the anthers I cm. long and slender. The pistil does not ustally emerge from the tube of the hypanthium, the stigma being seen in the very throat of the flower. The stigmatic lobes are very irregularly dereloped.

But few capsules are matured. The capsules are 15 to $18 \mathrm{~mm}$. long and 6 to 7 mm. in dianeter at the base, being finely pubescent with a few spreading hairs, bright green and slender, tapering slightly toward the apex.

The hypanthium in this species bears about the same relation to the reflexed sepals as in the parental form (plate 3 ).

\section{OENTIHERA LATA.}

O. latu was first seen by De Tries in the plantlets produced by seeds harvested at Hilversum, Holland, in IS 66 , and brought into bloom in 1 S 57 , and he has observed the origin of a total number of 493 as mutants in a progeny of the parental type embracing 1,30,000 plants.

It has been observed to arise in New York from the third generation of a strain grown from seeds furnished by Professor De Tries, and also in seeds obtained from Vilmorin in Paris.

A sowing was made of seeds of $O$. lata $\times O$. lamarckian furnished by Professor De Vries. This form is characterized by atrophied stamens which produce only a few pollen grains, of fairly normal strueture, which seem to be incapable of producing fertilization; but when the plant is pollinated by O. lamurkiana, lata characters appear in the first generation as forming from 
+ to 45 per cent of the progeny, or an arerage of 22 per cent. In the eultures made in New York, lata, if present, was mistaken for lamarckiana in the seedling stage and was discarded. Anlong the plants of this progeny which were finally brought to bloom were albila, oblonga, namella, and another type not recognizable by the authors.

Lata is to be regarded as a retrogressive departure from the parental type, and is most readily recognized by the rounded leaves of the rosettes, and these organs become rery much crinkled in later stages of development. The leaves are of a deep green, and the flower-buds are much thicker than any other erening-primrose known, except gigas, perliaps.

The principal taxonomic characters are as follows: The general habit of this spccies resembles that of $O$. gigas more nearly than any other of the mutants, being sparingly branched, and having short, stoutish branches on the upper portion of the stem. All of the branches are ascending, and in many of the plants the terminal portion of the stem is bent over.

The stem is channeled and angled, brittle, and both stems and branches are hirsute. The stem-leares are finely pubescent, 10 to $15 \mathrm{~cm}$. long, $t$ to 5 em. wide, numerous, and with the laminx remotely and shallow toothed. The leares of the rosettes, eren in the veryearly stages, are noticeably rounded and obtuse at the apex, and those of the lower part of the stem are spatulateoblong and rary to orate-oblong on the upper portions of the stem. Those on the upper part of the stem are either obtuse or acutish at the apex and taper to a margined petiole at the base. The leaves, even in young rosettes, are closely bunched into a head and are so heavily crinkled and thrown into convexities and concavities between the reins as to be easily distinguishable from all other forms in all stages of development.

The bracts are large, ovate to ovate-oblong, acute or obtuse at the apex, cordate or subcordate, and clasping at the base.

'the conic portions of the heavy buds are $2 \mathrm{~cm}$. long and $\mathrm{cm}$. in diameter in the basal portion, tapering so slightly as to appear nearly cylindrical, and are finely pubescent with spreading hairs. The free tips of the buds are spreading, stout, 4 to 5 mum. long. The hypanthium is about $35 \mathrm{~mm}$. long, stout, finely pubescent and much longer than the reflexed sepals (plate 4 and plate $5, \mathrm{~A}$ ).

The petals are thick, crinkled, and do not expand fully, being about 35 to 40 1mm. long, and 45 to $50 \mathrm{~mm}$. wide. The filaments are is to $20 \mathrm{~mm}$. long, while the anthers are inperfect, being very slender and abont $8 \mathrm{~mm}$. in length. The microseopical examination of the anthers showed a few pollen grains apparently perfect, yet no fertilization has exer been accomplished with them in Amsterdan.

In a recent paper $R$. R. Crates (1907) deseribes the results of an inrestigation of the pollen development of $O$. lata in which he ascribes the failure of the 
pollen to other causes than the ingrowth of the tapatum to fill the loculus. He found that derelopinant may proceed to the formition of tetrads, but frafuently degeneration begins in the resting stag of the first mitosis. Tlie sucessful pollinations recorde 1 below, however, demonstrate the functional nuturity of the pollen in many cases. Heterochromosomes were found to arise in the prophase after synapsis, both in lata and in the lamarkimu hybrid with latı. Inferentill support was secured for the supposition that the changes constituting mutation oseur during the reduction divisions.

The pistil is barely longar than the stamens, with the stigmatic lobes, heary and club-shaped, 6 to $7 \mathrm{~mm}$. long. The capsules are $1,3 \mathrm{~mm}$. long, about 6 to 7 nm. in diameter in the thickest portion, finely pubescent, many angled, and tapering slightly toward the apex. The terminal rosettes on the stem and branches were small and regular.

While this form has hitherto been found incapable of producing mature polken capable of effecting fertilization in repeated trials made in Amsterdan and New York, a notable exception is to be recorded. A package of seeds of O. lam whim?, which is growing wild near Birkenhead, England, was received from Mr. C. Theodore Green in I 905. A sowing made from this lot yielded the parental form, rubrineris, an 1 a few individuals of latu, which agreed with this form as derived directly from pure cultures so far as all external characters were concerned. Many individuals previously examined in various laboratories showed pollen which appeared normal under the microscops, yet no fertilizations could be secured. In the present instance, however, pollen appeared so plentiful that another attempt was made, the treated pistils being carefully guarded from pollination from the parental or other forms. A few pods were matured and some seeds were secured as a result. These were sown as soon as ripe, in September, 1906. The progeny showed ro lata, Solamarckiana, I albila, and is oblonga. No material difference between this and progenies resulting from pollination with lamarkiund was thus shown. In the latter ease the proportion of lat $z$ is often as low as + per cent of the entire progeny and has not been recorded to have gone beyond 4.5 per cent.

\section{()E.NOTHER.A OBLONCA}

O. oblonga was first observed by De Vries at Amsterdam in 1805 , although it doubtless appeared in his cultures previous to that time, as he suggests. In all it has arrived in joo mutants and in the pedigree-cultures chescribed in this paper in 35 individuals, only a part of which eame into bloom in August, 1905. agreeing with the observations in Amsterdam. (S)longa is one of the most easily recognizable of the derivatives of (). lamarkiana, although the distinguishing characters do not readily lend themselves to taxononic description.

The rosettes are not very dense; the leares in the young rosettes are narrowly ovate-lanceolate, rather thick and fleshy, with broad milveins which 
are sometimes distinctly reddish. 'The laminxe are shining green above, more or less puberulent on both surfaces, and obscurely denticulate.

The adult plant is less than I neter in height and is very sparingly branched below, with a few very short branches above. The basal branches are ascending and do not reach above lalf the height of the stem. Tlie stems are strongly channeled and angled.

The stem-leares are crowded, hang down, and are pubescent on both surfaces, 7 to io cm, long, oblong-elliptical, remotely and shallowly tootlied, acutish or obtuse at the apex, and irregularly narrowed into a short margined petiole. The lanina are strongly crinkled, dark green, and become tinged with crimson with age.

the bracts are oblong or ovate-oblong, acute at the apex, cordate or subcordate at base. Tle buds are reddish, the conic portion being about $2 \mathrm{~cm}$. long and finely pubescent with short spreading hairs and a few longer ones. The free erect tips are about 3 to 5 inm. in length. The petals are thin, generally crinkled, sonewhat emarginate and crenate, and are $3 \mathrm{~cm}$. long and 4 wide. In the unfolding of the flower the petals open only so far as to form a cup-shaped corolla. The hypanthium is about $3 \mathrm{~cm}$. long, slightly longer than the calyx-lobes. The slender ovary is about $8 \mathrm{~mm}$. long. The filaments are $15 \mathrm{~mm}$. long and the anthers $8 \mathrm{~mm}$. The pistils are slightly longer than the stamens, the stigmatic lobes being about $5 \mathrm{~mm}$. in length.

The capsules are 22 to $26 \mathrm{~mm}$. long and 6 to $7 \mathrm{~mm}$. in diameter at the thickest part, fincly pubescent, slightly angled and shining green, tapering slight ly to the apex (plate 6).

OENOTHIRA ALBIDA.

O. albi.l. was first recognized by De Vries as a mutant in $18 S 8$ and was brought into bloom in $\mathrm{s} 896$. It is distinguishable eren in the earlier stages by the paler color of the leares, which in the rosettes have upturned margins and are variously twisted. Serenteen examples appared in the cultures previously described luring roo5, of which 6 were mutants from O. lamarkiana as found introdnced on Nantuchet. The following taxonomic characters were observed :

Seedling about 3 months old: Rosettes 15 to $17 \mathrm{~cm}$. in diameter, thin, somewhat raised above the slender rootstock; leaves 7 to $10 \mathrm{~cm}$. long, 2.5 to 3 chl. wide, crect-spreading, the apex recurved and nearly touching the ground; blacles 5 to $7 \mathrm{~cm}$. long, oblong, broadest at about tle middle, acutish or mostly obtuse at the variously rounded apex, gradually tapering into the almost translucent, margined petiole, pale light green, very thick and britte, ninrgins unlulate-denticulate, some of the younger lasves strongly wrinkled on the nuargins. About 2 months later the rosettes were irregular, leaves twisted and various-erected, convexed upwardly, pale yellowish-green, approx- 
imately denticulate, oblong, soft-hairy on both surfaces, petioles winged laliway to base.

The adnlt plant was seen to be irregularly branched, the branches of ten exceding the main stem in length, which never reached a height of a meter. Stem zigzag, rather stout, channeled and angled, branching mostlyat base, both branches and stems very brittle. Branches and stems hirsute, witl spreading hairs and closely pubescent. Internodes short, with the leares crowded.

Stem-leares oblong to oblong-lancelate, more or less regularly denticulate. mostly obtuse or acutisin, nearly sessile, tapering at base, finely pubescent on both surfaces, very brittle and somewhat crinkled.

The bracts are oblong, acutish, or obtuse, slightly clasping, subcordate, erected when young, reflexed when mature, margins upturned.

The buds are distinctly reddish, $3 \mathrm{~cm}$. long, finely pubescent, with spreading hairs and the free tips erect and $6 \mathrm{~mm}$. long.

Hypanthium $+\mathrm{cm}$. long, slightly longer than the sepals. Petals thin, 35 to fo mm. long, and to to $50 \mathrm{~mm}$. wide, reflexed from the middle, deeply emarginate at the apex. Filaments 2 to $3 \mathrm{~cm}$. long, anthers $12 \mathrm{~mm}$. long Pistils longer than the stamens, with the stigmatic lobes $5 \mathrm{~mm}$. in length.

Capsules $35 \mathrm{~mm}$. long and 5 to $6 \mathrm{~mm}$. in diameter at thickest portion, finely pubescent and reddish, tapering slightly to apex. It is noticeable that comparatively few capsules are matured by this species. The terminal rosutes are symmetrical and the buds erect and prominent (plate 5, B, and plate 7 ).

\section{HYBRIDIZATION OF A MUTANT AND ITS PARENTAL TYPE.}

In order to test the results which have been presented by Professor De Vries with respect to the behavior of mutants in hybridization, a number of flowers of 0 . lamarckiana were castrated early in order to avoid entirely any probability of self pollination, and these flowers were pollinated from unopened buds of (O. mintrils. The resulting capsules were harrested early in September, Igo4, and sown in sterilized soil in the gresnhousesin November, 1904. Early in Jantary the seedlings were large enongh to make the separate types discernible, and the task of discarding tle duplicates was begun. The entire progeny was found to include go of lamarkima (and one of its mutants, of which 1 was present) and 221 rubrincris. The murineris, which is to be regarded as a progressive mutant of lamarkiana, has been seen to surpass it in regetative vigor and rapidity of growth, besides producing seeds quite as plentifully, and is sometimes dominant when crossed with the parent. 'l'hus De Vries found that when the above cross was made he obtained 19, 24, 68 . and it per cent of rubrinervis in four different lots, giving an average of totals of $t^{6}$ par cent rubrineris prodticed in such erosses. The culture described above yelded 7 per cent mbrintris. 


\title{
THE FL.UCTUATIONS OF OENOTHERA LAMARCKIANA AND ITS MUTANTS.
}

\author{
BY CE,TRE HARRISON SHLLL.
}

The results of statistical studies made in $190+$ on Oenothera lamarckiana Ser. and two of its mutants, (). nanella and O. rubrincris, were so suggestive that it was thought desirable to make a further attempt to trace the relations of the mutants to their parental form, as inclicated by the variations in some of their differentiating characters. In order to reduce the probable error, it was necassary to secure data from a larger number of individuals than the cultures at the New York Botanical Garden could supply. Consequently cultures of several of the oenotheras were begun at the Station for Experiniental Evolution.

The cultures which form the basis of this comparative study were the following:

(a) About go specimens of $O$. lamarckiana were grown from seed supplied under the designation D.I.S by the senior author, being seed from plants guarded and purely self-fertilized for three generations in the New York Botanical Garden, and thirteen generations preceding in the Botanical Garden at Amsterdam. In this, as in all the following cultures, no selection of specimens was made, the desired number of plants having been taken consecutively, beginning at one side of the seed pan; and in all cases the arrangement in the garden was the same as that adopted at the New York Botanical Carden, $i . e$, the plants were placed at a uniform distance of i meter from each other. One of these 90 individuals was an (). lata and was omitted from the statistical studies on this plot. The remaining 89 specimens were typical O. lamarckiana.

(b) Ten rosettes of (lenothera lamarckiana were received by mail from Prof. De Vries April 7, igo5, laving been collected by him in the open freld near Hilversum, Holland, where over twenty years ago he secured the original stock for his pedigree-cultures; 9 of these came to blonm and were uniform in apparance, agreeing well with the other cultures of (). lamarcliana in all characters but those whose differences could be appropriately attributed to the fact that these plants had grown as biennials, while the others had been foreed to annual bloom by giving an early start in the propagating house. The chicf differences between these plants and those of the culture described abore were seen in the greater height and more numerous and longer branches of the plants from Hilversum. The rosette leaves were more numerous and larger in both dimensions, but had the same form and the same degree of crinkling. 
(c) Eighty-eight specintens were grown from seed of an (). mbrineris which had appeared as a newly arisen mutant among the first generation hybrid progeny of 0 . lamarckiana $\times$ bicnnis discussed in our earlier account (Mutants and Hybrids, p. is). The occurrence of this mutant aloug with sereral individuals of $O$. lamarckinna was there attributed to an accilental self-fertilization of the pistil parent, but there is no sufficient reason perlaps for ruling out the oceurrence of monolepsis producing Millardet hylurids in which the maternal characters alone appear. Ithether this specincen of (). rubrineris was the product of self-fertilization or of monolepsis has no especial significance for this study, since, whatever may have been its origin, it was a true $O$. mbrinervis, though having no mbrineris individuals in its ancestry, at least for many generations.

The pollination of this specimen was left entirely uncontrolled, and as it grew in close contiguity with other species of (D) nothera, where insects were husily engaged carrying from flower to flower the pollen of a dozen or more different species, the progeny might have been expected to show a confusion of hybrid forms of mnknown affinities. It was a matter of some surprise. therefore, that only i specinen in the 88 appeared to be a hybric. The characters of this obvious lybrid indicated that it was probably produced by pollen from one of the small-flowered species, and it was considered by the senior author to be nearly if not quite identical with his O. lamarckiun bicnnis, No. 2.32, though no definite analysis of its cluaracters was made. The other $S_{7}$ - individuals consisted of $S_{0} O$. mbrincris and 7 which were looked upon as typical (). lamarckiana, although, as will be seen later, the results of the statistical studies present some interesting exceptional features.

(d) Twenty-seven individuals of O. mbrincris were grown from guarded and self-fertilized seed of one which arose as a mutant at Ansterdam in 189.5 in a pure $O$. lamarckiana pedigree guarded for six generations.

(e) Ninety-eight specinens of Oenothera gigas were grown from pure-bred seed received from Prof. De Vries, the pedigree being known and fully guarded for fire generations from the time it appeared as a mutant in 1895 . Unfortunately only + of these cane to bloon the first vear, so that the studies here given on Oenothera gigas must be considered wholly inadequate.

(f) Another lot of plants, $+t$ in number, were the offspring of Oenother lata which had grown surrounded by $O$. gigas in an isolated portion of the Botanical Garden of Ansterdam. On the side of the pistil-parent the pedigree of this latu had been continued for five generations from the time it arose as a mutant, and in most of these generations ( . lamarkiuna was the pollen parent. As O. lata is nearly or quite incapable of self-fertilization, owing to its lack of viable pollen, these plants must have been hybrids between O. Lutu and $O$. gigas, and as they were wholly unselected they formed a motley gronp. Among them Oenothera lata was the nost frequent, $1 ;$ in +4 belonging to this 
species; 15 were $O$. lamarckitnt, and 2 were $O$. nanclla. The remaining io were not positively identified, though several which were at first thought to be $O$. lata but which were afterwards seen to differ fron that species in eertain bud characters, especially in the possession of pollen-bearing anthers, may have been true hybrids between $O$. lata and $O$. gigas.

The advantages of bringing together to one place for use in this line of investigation material having such different past histories will be obvions. If the various types of structure which have been separated and deseribed under specific names are not perfectly natural centers of stability, or rather of ecinilibration, but are the product of selection, it is inconceivable that the forms resulting from selection by different persons for different periods of time and in different environments should produce identical forms, and especially that there should be identity in characters that were not taken into account and could not well be taken into account by those making the selcetions.

Some differences are naturally to be expected in the characters of these several lots of plants of the same species coming from different sources, because of the known behavior of purely fluctuating characters, and the degree of these differences will be contemplated with some interest. On the other hand, the various sourees of the material will make the comparisons between the different species less satisfactory than might be wished.

A part of the advantage gained in the way of larger quantities of material by bringing these cultures to the Station for Experimental Evolution is offset by the fact that differences in soil, climate, and methods of culture from those to which the cultures were subjected at the New York Botanical Garden in $190+$ will make impossible the drawing of any conclusions this year regarding the problen which originally incited these investigations, namely, the cluestion as to the presence or absence of regression in the mutants. As a partial measure of the difference in conditions at the New York Botanieal Garden in $190+$ and at the Station for Experinental Evolution in 1905, a comparison of the heights of the O. lamarckiana used for the studies in the former year may be made with those of the first lot $(a)$ described on page 18 . Both of these lots were raised as annuls and should therefore give a reasonably fair indication of the relative value of the resultant of atl the factors affecting the fluctureting characters of the two lots of plants.

The height-curves recluced to equal areas are shown superposed in fig. I, and the principal constants are as follows:

\begin{tabular}{|c|c|c|c|}
\hline & Mean. & $\begin{array}{l}\text { Standard } \\
\text { deviation. }\end{array}$ & $\begin{array}{l}\text { Coefficient } \\
\text { of rariation. }\end{array}$ \\
\hline $\begin{array}{l}\text { New Vork Potanical Garden, no.t. ...... } \\
\text { Station for Ixperimental livolution, ioos. }\end{array}$ & $\begin{array}{l}\text { Contimeicrs. } \\
88.08 \pm 0.55 \\
86.08 \pm 0.69\end{array}$ & $\begin{array}{l}\text { Crnimeicrs: } \\
+.76 \pm 0.39 \\
\text { S. } 37 \pm 0.19\end{array}$ & $\begin{array}{l}\text { Jer ccut. } \\
5.37 \pm 0.1 t \\
0.62 \pm 0.57\end{array}$ \\
\hline
\end{tabular}


It will be noted that there las been a slight fall in mean heiglits, but the most noteworthy thing in this comparison is the great increase in the variability. A study of fig. I shows the difference in variability quite clearly in the greater amplitude and less height of the igos curve. The interesting fact becomes apparent that althougl the mean value of stem-heights in 1905 was less than that for 1904 , some of the 1905 plants were taller than the tallest in Igof. The explanation of these facts is very simple. The garden at the Station for Experimental Erolution has been under cultivation so short a

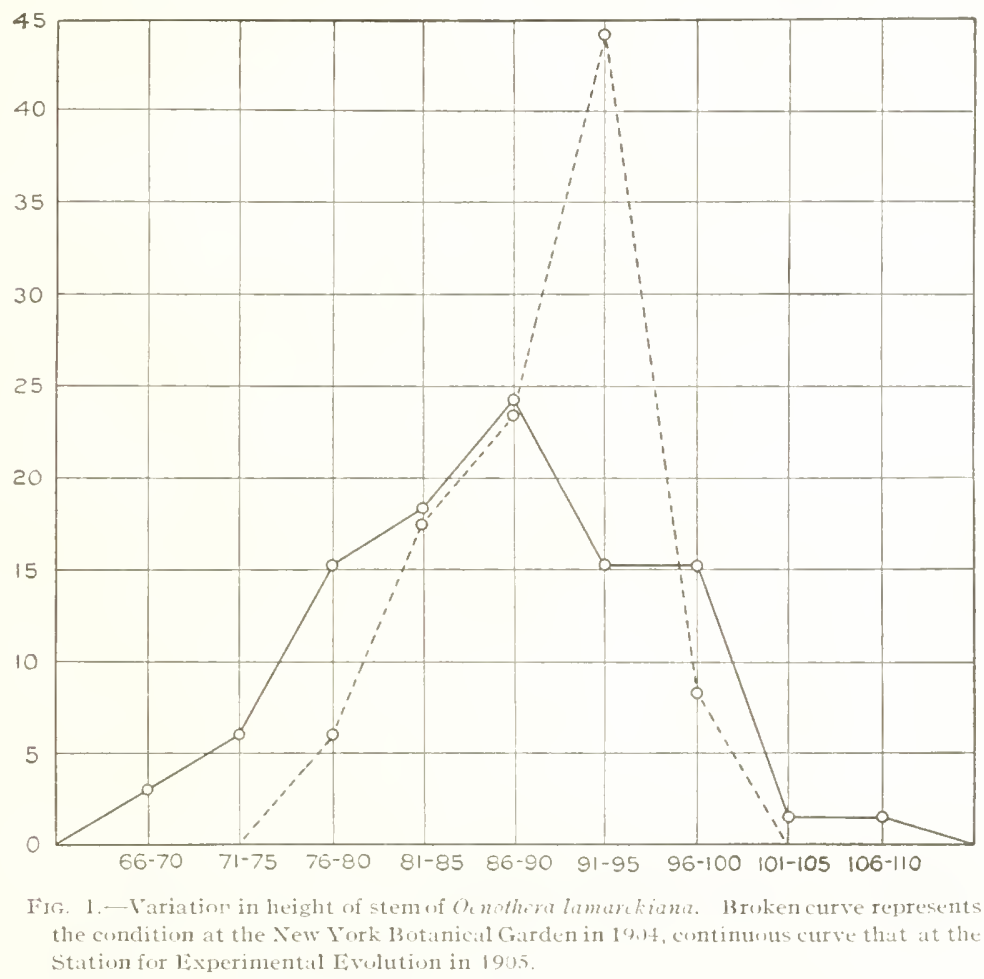

time that it still lacks much of that homogeneity that is desirable for work of this nature. One corner of this plot of Cenothera lamarckiana dipped into a slight clepression which received the drainage from the roof of the laboratory and was therefore kept. during a portion of the growing season, too wet for the best development of the plants. A few specimens on this corner did not make flower-stems at all, and it was to be expected that those nearest this corner of the plot would be somewhat influeneed by the same unfarorable conditions and made to prodice flower-stens of a slightly less altitude.

The stature of Oenothera mbrineris. - In 1904 a comparison was made between the statures of Ocnothera nanclla and (). lamarkinnt, and it was a 
part of the plan for the present study that this comparison should be continued, but unfortunately the seed of (). nanella gave only 3 germinations and the continuation of this comparison nutst be postponed until another season, but meanwhile it will be particularly interesting to make another comparison of heights which will present something of a contrast with that between $O$. namella and its parent. It will be realled that in that comparison the coexistence of two striking features was taken to be more than a mere conncidence, namely, the great departure of the mean value in $O$. nanclla from the

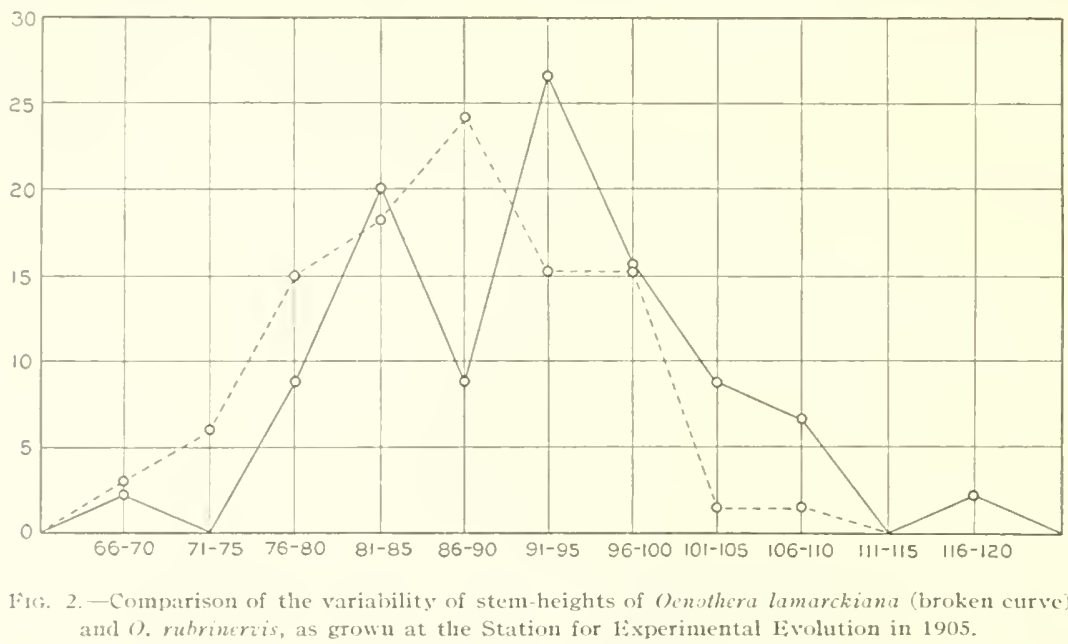

mean of its parent, and a very great increase in the coefficient of variability in the heights of the mutant. In conparing the heights of $O$. rubrineris with those of (). lamarckiana there is seen a very much less marked departure from the parental condition in the mean values, and a correspondingly sliglit increase in the coefficient of variability. This comparison is shown graphically in fig. 2 and is expressed numerically as follows:

Trariation in heights, 1905.

\begin{tabular}{|c|c|c|c|}
\hline & Mean. & $\begin{array}{l}\text { Standard } \\
\text { deviation. }\end{array}$ & $\begin{array}{l}\text { Coeffieient } \\
\text { of variation. }\end{array}$ \\
\hline $\begin{array}{l}\text { Oenothera lamarckiana . . . . . . . . . . } \\
\text { ()enothera rubrinervis . . . . . . . . }\end{array}$ & $\begin{array}{l}\text { (entimeters. } \\
86.95 \pm 0.69 \\
92.18 \pm 0.99\end{array}$ & $\begin{array}{l}\text { Contimeters. } \\
837=0.49 \\
9.86 \pm 0.70\end{array}$ & $\begin{array}{l}\text { Per cent. } \\
0.62 \pm 0.57 \\
0.70 \pm 0.78\end{array}$ \\
\hline
\end{tabular}

This may still be merely a coincidence, but two such coineidences are very much less likely to ocenr than one, and the attempt will be made in the study of other cliaracters to trace the stiggested parallel between the departure of the mean fron the parental condition and the increase in the value of the coeffieient of variability. 
The branching habit of Oenothera mbrinervis.-In discussing the loranching of Oenothera rubrineris in root the statement was made that "such a character as this is too largely influenced by the individual physiological vigor to be of any value as a diagnostic character," and this statement receives striking confirmation in the conditions observed in 1905. The specimens of C. rubrineri. grown at the Station for Experimental Evolution in the latter year were totally different in their branching from those studied the year before at the

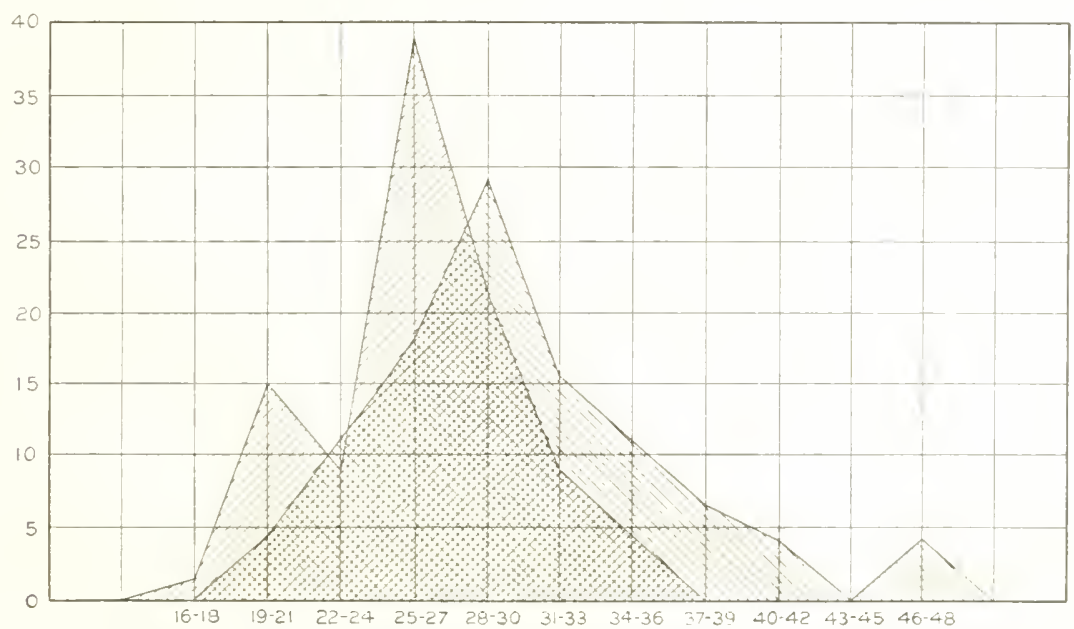

Frg. 3.-Comparison of the number of branches of Oenothere lamarkitua (sliaded with lines rising toward the right) and O. vubrineris, as grown at the Station for Experimental Evolution in 1905.

New Tork Botanical Garden. There was in 1905 almost a complete suppression of the large basal branches which were such a marked feature of the specimens earlier described. Instead of finding Oenothera lamarckiana and $O$. rubrineris entirely distinct and separated by a wide gap in respect to number of lateral branches, the curves in figure 3 show how greatly they overlap. Their numerical relations may be studied in the following table:

\begin{tabular}{|c|c|c|c|c|}
\hline & Range. & Mean. & $\begin{array}{l}\text { Standard } \\
\text { deviation. }\end{array}$ & $\begin{array}{l}\text { Coefficient of } \\
\text { variation. }\end{array}$ \\
\hline $\begin{array}{l}\text { Number of the lateral } \\
\text { branches: }\end{array}$ & & & & Percent. \\
\hline Oenothera lamarckiana. . & 18 to 39 & $2620 \pm 0.33$ & $3.99 \pm 0.33$ & I $5.23 \pm 09 \mathrm{I}$ \\
\hline $\begin{array}{l}\text { Oenothera rubrinervis... } \\
\text { Total branch length in } \\
\text { decimeters: }\end{array}$ & 19 to 77 & $30: 8 \pm 0.72$ & $6.12 \pm 0.51$ & $20.29 \pm 1.76$ \\
\hline Oenothera lamarckiana. . & 40 to 150 & $91+40 \pm 1+4$ & $1797 \pm 1.05$ & $19.66 \pm 1.20$ \\
\hline Oenothera rubrinervis... & $4: 20174$ & $8, .22 \pm 2.36$ & $2.3 .+6 \pm 1.67$ & $26.89 \pm 2.05$ \\
\hline
\end{tabular}


With respect to the number of branches, the figures in this table do not fully represent the tendency in 0 . mbrinervis to develop a large proportion of its axillary buds intobranclies, as many of these buds had started into growth, but for some reason had been arrested before they had attained a length of I cm., under which length none were counted. Comparing these results with those of 1904 it is found that with respect to variability Oenothera lamarckiana presents essentially the same condition in the two years, though the values of both number and length of branches has increased in the latter year. In Oenothera rubrineris, on the other hand, although there has been in 1905 a great reduction both in number and length of branches and the coefficients of variability ure considerably changed, they are still much higher than in the parent species. This will be best appreciated by a comparison of the results for the two years as shown in the following table:

\begin{tabular}{|c|c|c|c|c|c|}
\hline Tariation in- & lears. & - Range. & Mean. & $\begin{array}{l}\text { Standard } \\
\text { deriation. }\end{array}$ & $\begin{array}{l}\text { Coefficient } \\
\text { of variation. }\end{array}$ \\
\hline anches of 1 & $100+$ & Io to & 20.2 & $3.2+t$ & $\begin{array}{l}\text { Per cent. } \\
\text { - }\end{array}$ \\
\hline o. lanarckiana. & 1005 & I8 to 39 & $26.20 \pm 0.33$ & $3.99 \pm 0.33$ & $15.23 \pm 0.9 \mathrm{I}$ \\
\hline Ninuber of branches of & $190+$ & $3+1063$ & $42.35 \pm 1.04$ & $6.34 \pm 0.73$ & $15.00 \pm 1.70$ \\
\hline 0. rubrinervis. & 1905 & 19 to 47 & $30.18 \pm 0.72$ & $6.12 \pm 0.51$ & $20.29 \pm 1.76$ \\
\hline Branch-length of $O$. ? & 1904 & 36 to $S_{5}$ & $66.8 \pm 2.0$ & $13.5 \pm 1 .+$ & $20.2 \pm 2.2$ \\
\hline lamarckiana. & 1905 & to to I 50 & $91.4 \pm 1.5$ & $18.0 \pm 1.1$ & $20.0 \pm 1.2$ \\
\hline Branch-length of $\mathrm{O}$. I & $190+$ & -8 to 300 & $181.9 \pm 13.0$ & $79.5 \pm 92$ & $+3.7 \pm 5.1$ \\
\hline rubrinervis. & 1905 & 4 to 174 & $87.2 \pm 2 . t$ & $23.5 \pm 1.7$ & $26.9 \pm 2.0$ \\
\hline
\end{tabular}

The greater variability of the mutants was taken in 1904 to indicate that these forms might not yet have acquired, perhaps, that fixity of habit exhibited by an older species, and the fact that Oenothera rubrineris underwent greater change in its mode of brancling on being cultivated in a new environment than was exhibited by O. lamarckiana when subjected to the same change would accord well with this suggestion.

The increase in the number and length of the branches in O. lamarckiana and the considerable decrease in those of $O$. rubrinervis must not be interpreted, however, as in any sense an approach to actual identity in these two species, in regard to branching habit, for in the latter year they were even more distinct in general type of branching than before. Ocnothera rubrinevis liad simply lost its long basal branches, while $O$. lamarkiana had retained them.

THI: SIZE AND SHAPE OF IIAAVIS OF OFAOTHERA RUIRINERTIS.

Some of the difficulties attending the statistical study of leaves were pointed out in our earlier paper, and the complete suppression of the basal branches of 0 . rubrincris in 1905 has made the continuation of the comparison between 
the leaves of that species and those of its parent of little vahuc except as a demonstration of the difficulties which were to be overcome. It seemed fair in the former year to consider the basal branches of these two species homologous, and leaves for the study in 1904 , being taken from about the middle of those branches, were consequently as nearly comparable as possible. In 1905 the leaves of $O$. lamarckiana were again taken from the middle of the basal branches and are thus comparable with those of 1904 , but in $O$. rubrinervis the leaves were taken from the middle of the lowest branches present, and as these were not quite basal, the leaves were not homologous with those of O. lamarkiana. The first striking result of this lack of homology is seen in fig. 4 . where the variation in leaf-lengths is compared. The corresponding curves for 1904 showed almost exact identity in the length of the leaves, while in this figure it is seen that the length of most of the O. mbrinervis leaves corresponded in 1905 with the lower part of the range of $O$. lamarckiana. When figure 5, representing the variation in leaf-width, is compared with the corresponding figure for 1904 it is seen that with respect to this character the lack of homology has had but little modifying effect, and there is close resemblance between the sets of curves representing the variation in leaf-width for the two years, though both species show a slight increase in the coefficient of variability. The consiclerable difference in respect to leaf-length, taken in conjunction with essential identity in leaf-width in 1905 , has the effect to change the ratios between length and width in about the same degree as the change in length, but in the opposite direction. Thus the change in length was away from identity;

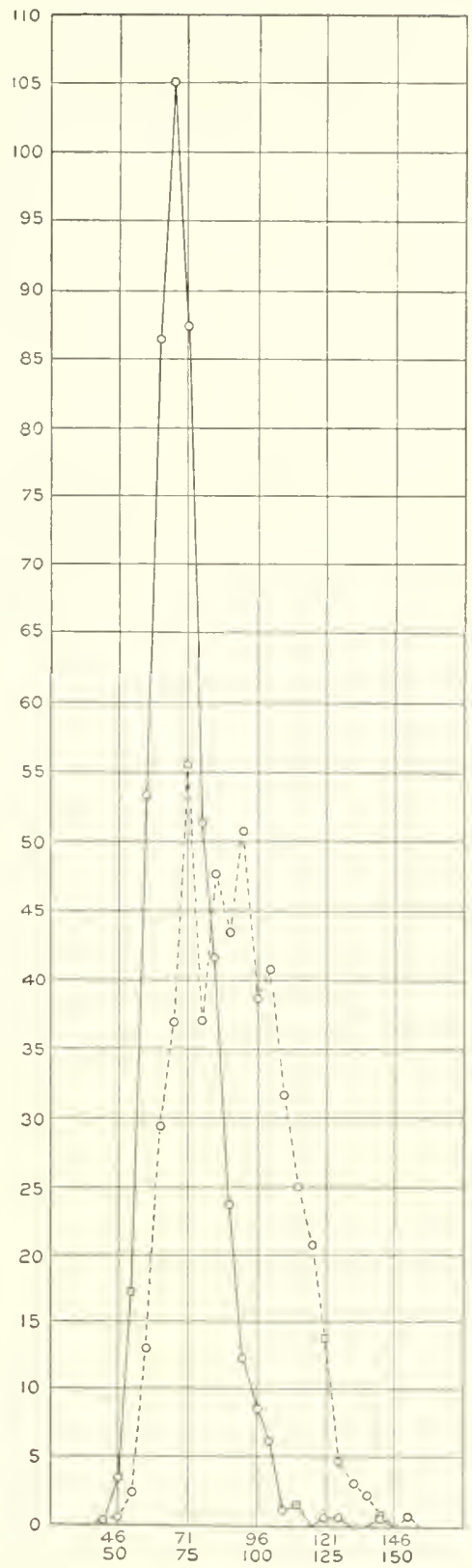

Fig. 4.-Comparison of leaf-length of Oenothera lamarckiana (broken curve) and $O$. rubrineris 


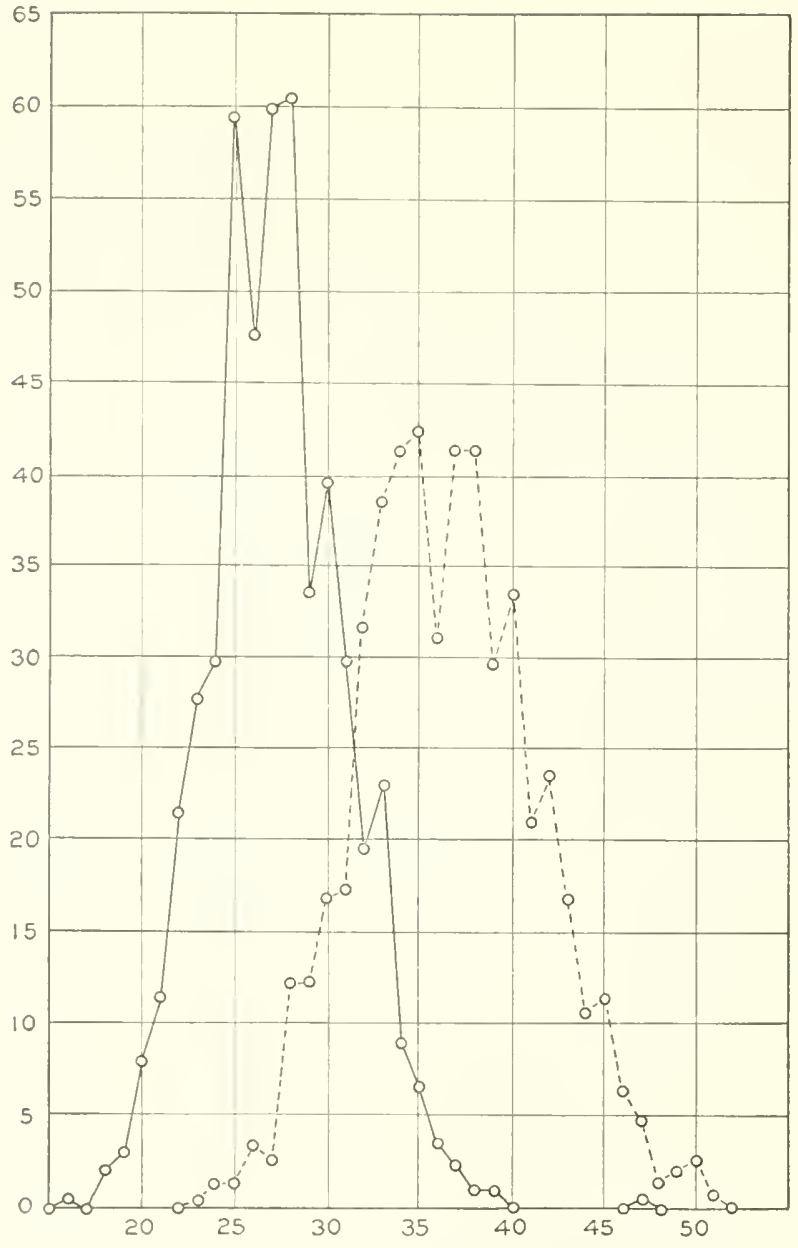

liIG. 5.-Comparison of leaf-width of Oenotheralamarckiana (brokencurve) and $O$. rubrinerris. while that in the leaf ratios was towardidentity, as will be readily seen on referring to fig. 6 , which sliows a much more complete overlapping than do the corresponding curves for 1904. In other words, since this ratio was taken as a measure of leaf-form, the form of the leaves of $O$. rubrinervis in the latter year was but slightly different from that of the parent species, except in those minor details which were pointed out in the carlier study as preventing the ratio between length and width from being a correct measure of form. The lack of lomology in the leaves measured in the two species takes away all significance of these facts in their bearing on the question of the

regression of $O$. rubrinervis. The constants of the several curves representing the variation in leaf measurements may be compared in the following table:

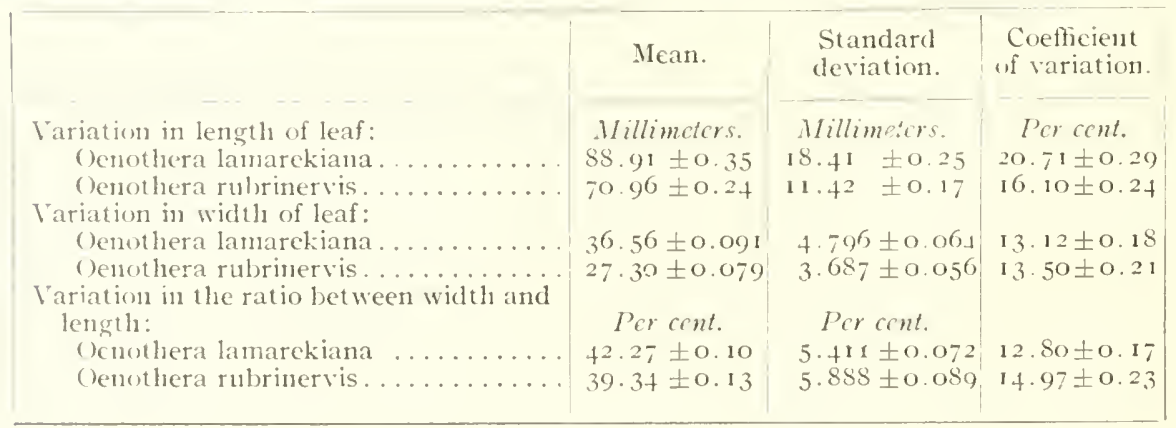


The original measurements upon which the above figures and conclusions are based are presented in the form of correlation tables in figs. 7 and 8 . A comparison of the tables with the corresponding figures for $190+$ shows that those representing $O$. lamarckiana are very much alike in the two years, the degree of correlation being even higher in the latter year than before, due in part possibly to the slightly greater heterogeneity already pointed out in the eultures at the Station for Experimental Evolution. On the otler hand, in Oenothera rubrineris the eorresponding tables for the two years are entirely

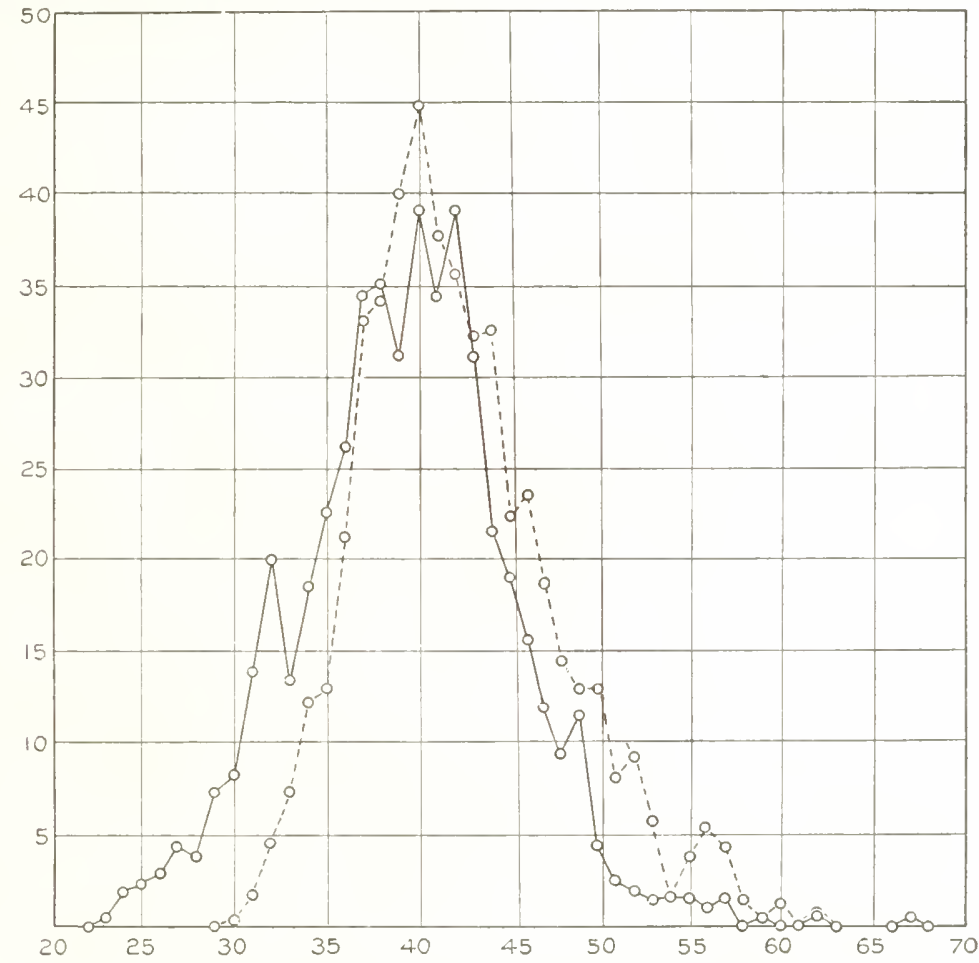

Fig. 6. Compirison of the ratio between leaf-length and leaf-width in $U^{\prime}$ nothero lamarckiana (broken curve) and $O$. rubriniris.

different, as would be expeeted from what has already been said. In this species the coafficient of correlation has been considerably lowered.

The eoefficients of correlation for the two species for the two years may be compared in the following table:

\begin{tabular}{|c|c|c|}
\hline & 1004. & 1905. \\
\hline 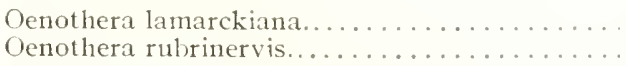 & $\begin{array}{l}0.7916 \pm 0.0090 \\
0.6604 \pm 0.0119\end{array}$ & $\begin{array}{l}0.83,30 \pm 0.0058 \\
0.4+52 \pm 0.0171\end{array}$ \\
\hline
\end{tabular}




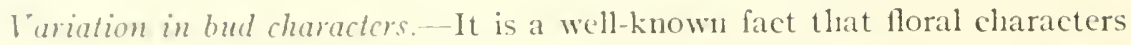
fluctuate less in response to change of environment than vegetative characters, though I know of no exact studies showing to what extent this is true. 'The comparatively larger flowers of alpine regions fincl an explanation on this basis since the alpine plants have generally migrated from the lowlands. I have seen a specimen of Lobetia syphiliticu less than 8 cm. tall and dwarfed

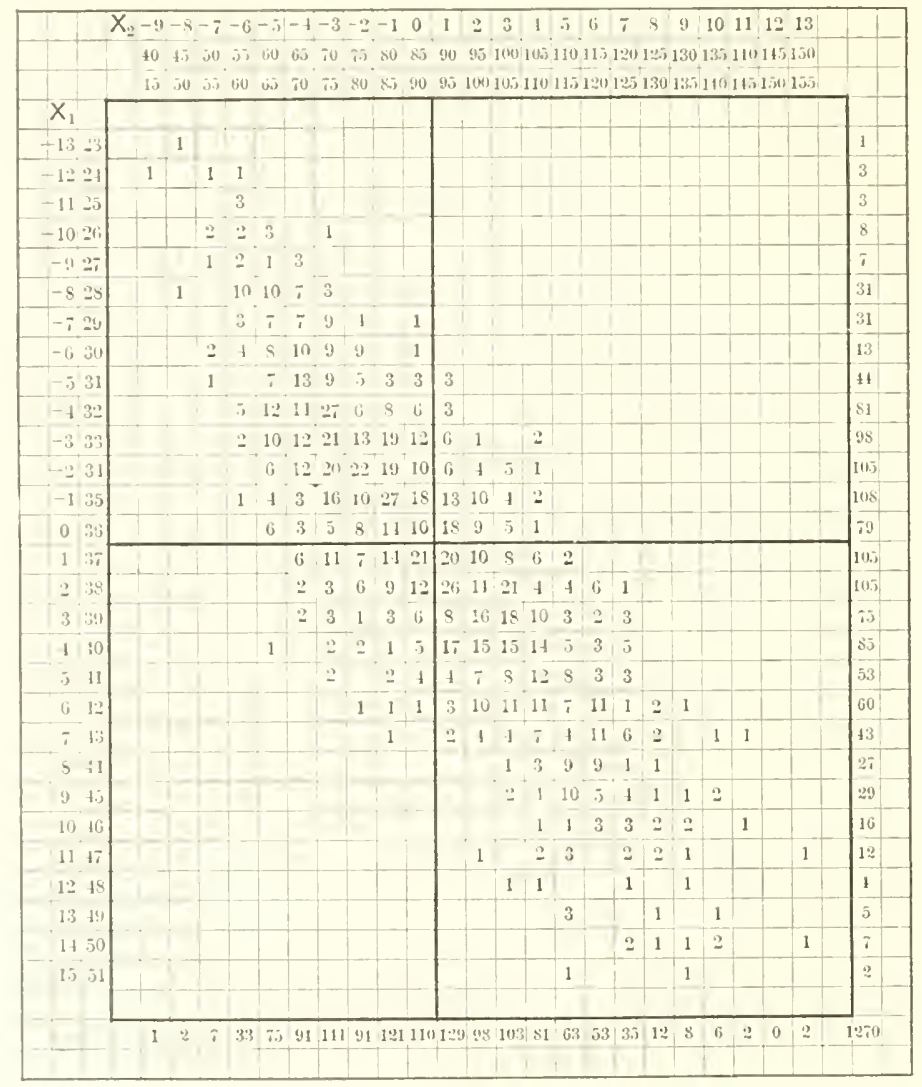

1:Is. 7.-Correlation between width (subject) and length of leaf in Ocnothera lumarckiana. Measurements in millimeters. Coxfficient of correlation, $0.8330 \pm 00058$.

specinnens of numerous other species bearing flowers almost as large as is normal for the species.

Iaving sufficiently demonstrated the unsatisfactory claracter of height, branching, and leaf-form for statistieal comparisons because of their great sensitiveness to even slight changes in the enviromment, I have decided that in the buds is to be found probably the most satisfactory material for a continuation 
of these studies. The oenotheraceons bud offers distinetive characters for the separation of the several species (plate 8 ). It las, as is well known, there distinet regions, the ovary, the hypanthium, and the eone-which are in most cases marked off from each other in such a way as to make their accurate measurement easy. As proof of this fact it is only necessary to say that irequent repetitions of the meastrements slowed only a variation of onetenth of a millimeter in the thickness of ovary and hypantlium, and from 0.2 too. 311111 . in thickness of the cone and lengths of the several regions, the maxinum error in the smallest measurement s taken being less than + per cent of the magnitude measured, and in the largermeasurements. such as length of hypanthium and cone, less than I per cent.

In deciding to make statistical studies on buds a careful preliminary survey was made to determine what precautions would need to be taken

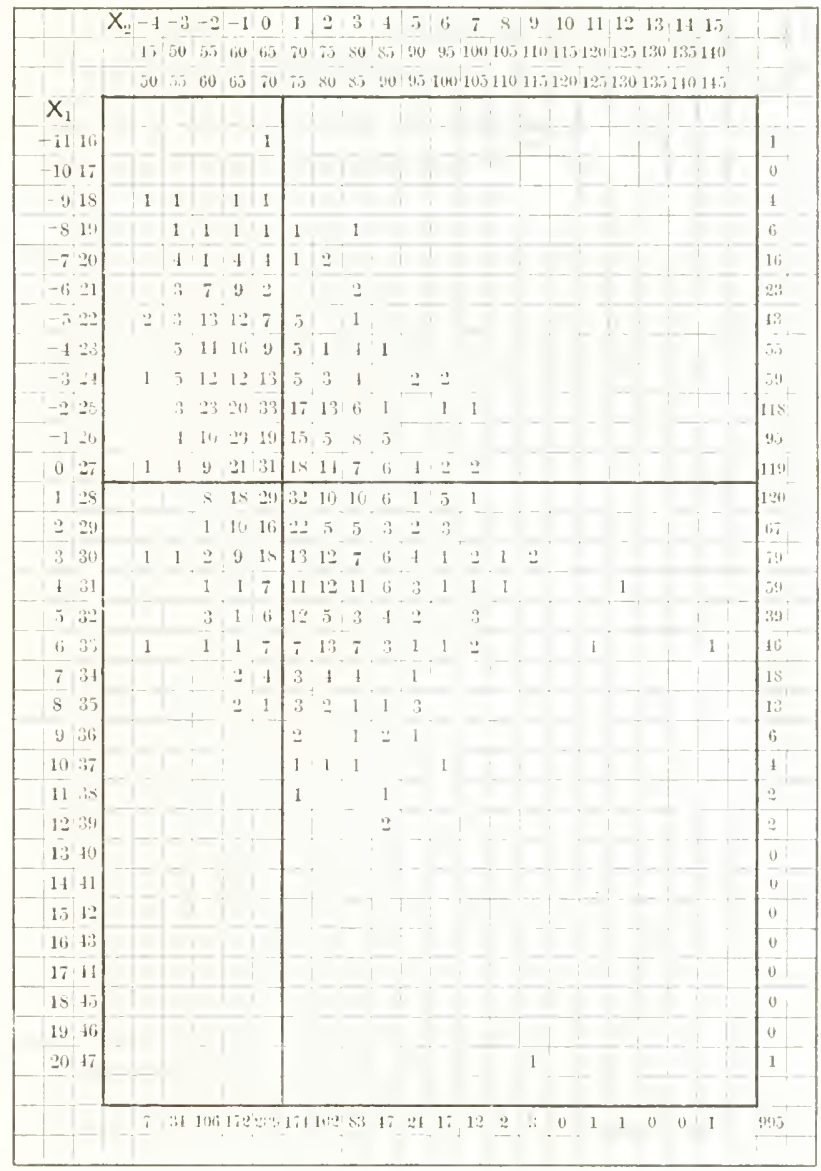

Fis. 8.-Cortelationbetween wielth (subject) and length of leaf in () mothew numineris. Meiturements in millimeters. Coefficient of correlation, $04452 \pm 0,0171$.

in order to free the work from error. The several points that seemed to need consideration were: (a) A probable periodicity in the size of the buds, so that those in the early part of the season are doubtiess a little larger than those produced near the end of the season, but as the flowering season is very long this periodicity is certainly slightand would probably have no appreciable influence 
during the greater part of the season if the earliest and latest flowers are omitted. (b) A variation in the size of the buds in response to different conditions of the weather. While this variation is not often great enough to be noticeable, there were times at which the buds seemed distinctly larger after several days of warm, humid weather. Both of these difficulties would be rendered comparatively hamless by a collection of a small number of buds each dayfrom each of the lots of plants studied, so that all were being subjected to the same conditions. 'There are still some elements of error, however, which this method does not fully meet, such, for instance, as the existence of a different period in the different species, or a clifferent kind or degree of reaction to changes in the weather. Without an extensive study of the periodicity and

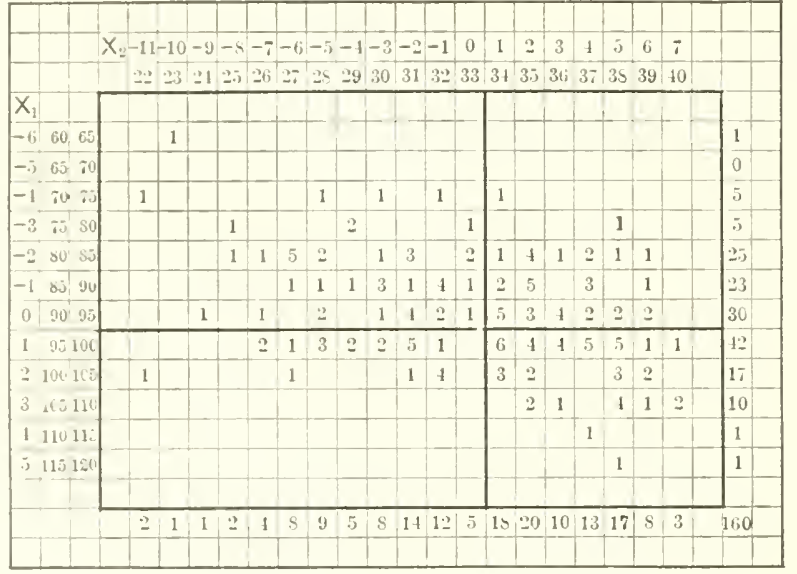

1:IG. 9.-Correlation in the buds of Otnotheralamarckiana from litversum. 1.ength of ovary subject, length of hypanthium relative. Coefficicnt of correlation, $0.3872 \pm 0.0453$. response in the several species to changed climatic conditions it can not be known just how serious errors these factors introduce, but it is believed that they are slight. (c) There is always present a complete series of buds, beginning with those ready to bloom and ending with those just beginning to develop, and the development is so rapid that buds collected at one hour of the day are not the equivalent of those collected at any other hour. It was found on cxamination that the buds which would bloom the following day could be readily distinguished by their size and color. Rarely there would be a doubt about some particular bud, and such were onitted from the study. To avoid the collection of buds at different stages of development they were collected from all the lots at 5 p. m. and measured as soon thereafter as possible. This nukes all the buds used in these studies as nearly comparable as could well be sectred, though it is realized that a source of slight error is to be found in the fact that on some days the derelopment of the buds is more rapid than on others, so that they are not always quite equivalent at the time of collection, when this is determined by the clock without regard to the weather. 
This work was not begun until late in the season, the first collection of bucls for this sturly having been made on September 15 and the last on Oetober 30, and this will need to be taken into account in making future comparisons, though it seems likely that the periodicity is too slight to make this a modifying factor of any considerable moment.

The number of buds from each lot of specimens, exeept one, was from 1 to to i6r. In Oenothera gigas only 9r buds were secured before frost eut short the investigation. The lateness of the time at which the work was begun prevented the measurement of a larger number of buds of each lot, though it is realized that a much larger number would be desirable. On this account it is not thought necessary to present variation curves of each tot of measurements. Instead, the constants have been calculated and are presented in the form of a table:

\begin{tabular}{|c|c|c|c|c|c|c|}
\hline & \multicolumn{3}{|c|}{ Length of ovary. } & \multicolumn{3}{|c|}{ I.ength of hypanthium. } \\
\hline & Mean. & $\begin{array}{l}\text { Standard } \\
\text { deviation. }\end{array}$ & $\begin{array}{l}\text { Coefficient } \\
\text { of variation. }\end{array}$ & Mean. & $\begin{array}{l}\text { Standard } \\
\text { deriation. }\end{array}$ & $\begin{array}{l}\text { Coefficient } \\
\text { of variation. }\end{array}$ \\
\hline & Deci-millimeters. & Deci-millimeters & Per cent. & Mollimeters. & Millimeters. & Percent. \\
\hline$a$ & $95.67 \pm 050$ & $9.33 \pm 0.35$ & $9.75 \pm 0.39$ & $33.06 \pm 0.23$ & $+.20 \pm 0.16$ & $12.71 \pm 0 .+9$ \\
\hline$b$ & $9176 \pm 0 .+7$ & $3.73 \pm 0.33$ & 9. $52 \pm 0.36$ & $33.07 \pm 0.22$ & $+.18 \pm 0.16$ & $12.6 ; \pm 0 .+8$ \\
\hline$c^{\prime *}$ & $92.29 \pm 034$ & 6 to \pm 0.24 & $69+ \pm 0.26$ & $29.10 \pm 0.22$ & $+\mathrm{I}+ \pm 0.16$ & $17.23 \pm 0.55$ \\
\hline$c 1$ & $107.56 \pm 0.53$ & $9.89 \pm 0.37$ & $9.20 \pm 0.35$ & $30.37 \pm 0.21$ & $3.85 \pm 0.15$ & $12.77 \pm 0.49$ \\
\hline$d \mathrm{I}$ & IIS.S1 $10 .+7$ & $8.10 \pm 0.33$ & $7.07 \pm 0.28$ & $30.33 \pm 0.18$ & $3.24 \pm 0.13$ & $10.69 \pm 0.43$ \\
\hline e 1 & $102.12 \pm 0.64$ & $9.01 \pm 0.45$ & $8.83 \pm 0.44$ & $25.18 \pm 0.37$ & $5.29 \pm 0.26$ & $21.00 \pm 1.09$ \\
\hline$f$ & $83 .+2 \pm 0 .+4$ & $7.77 \pm 0.31$ & $9.31 \pm 0.3^{8}$ & $26.96 \pm 0.32$ & $5.61 \pm 0.23$ & $20.80 \pm 0.87$ \\
\hline
\end{tabular}

Length of cone.

Millimeters. Millimeters

a $39.47 \pm 0.193 .47 \pm 0.13$

b 39.t7 $10.183 .+5 \pm 0.13$

$c^{\prime} \quad 37.50 \pm 0.1+2.65 \pm 0.10$

$35.52 \pm 0173.20+0.15$

$36.35 \pm 0.132 .277 \pm 0.090$

$39.51 \pm 0.365 .29 \pm 0.26$
$30.27 \pm 0.24+.27 \pm 0.17$
Thickness of ovary

Deci-mallimeters. Deci-millimeters

8. $79 \pm 0.3+32.37 \pm 0.101 .932=0.0-3.5 .97 \pm 0.23$ S. $7+0.33 \quad 33.5 \mathrm{I}+0.112 .0-5 \pm 0.0-b 6.20 \pm 024$

$7.01 \pm 0.26 \quad 31.261 \pm 0.0911 .7$ I $\pm 0.0645 .47=0.21$

9. $26 \pm 0.3533 .76 \pm 0.1+2.540 \pm 0.0967 .52 \pm 0.25$

$6.26 \pm 0.2536 .+9 \pm 0.112 .041 \pm 0.001 \quad 5.59 \pm 022$

$2.75 \pm 0.65+1.76 \pm 0.31 \quad 3.69 \pm 0.22 \quad 8.30 \pm 0.49$

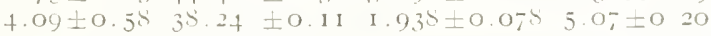

Thickness of hypanthium.
Thickness of cone.

Deci-millimeters. Deci milloneters

Dert mallimitos. Decimalimeter

a $\quad 25.29 \mathrm{I} \pm 0.068 \mathrm{I} .26 \mathrm{I} \pm 0.04 \mathrm{~s}+99 \pm 0 \mathrm{I0} 34.50 \pm 0.30 \div .21 \pm 0.27$

b $26.069 \pm 0.0701 .320 \pm 0.0 .50 \quad 5.06 \pm 0.118 \mathrm{~s} .81 \pm 0.326 .00 \pm 0.23$

$25.453 \pm 0.07+1.389 \pm 0.0525 .46 \pm 0.21 \quad 87.60 \pm 0.3 .56 .63 \pm 0.25$

$28 .+6 \pm 0.10 \quad 1.9+0 \pm 0.0736 .82 \pm 0.26 \quad 9.3 .26 \pm 0+3$ s.0. \pm 0.30

$30.356 \pm 0.0701 .259 \pm 0.050+1.5 \pm 0.1693 .47 \pm 0.205 .17 \pm 0.20$

$36.45 \pm 0.273 .46 \pm 0.179 .48 \pm 0.48109 .76 \pm 0.699 .79 \pm 0+9$

29. $157 \pm 0.0 \$ 11 .+22 \pm 0.057+.85 \pm 02096 .+1 \pm 0.475 .13 \pm 0.33$

S. $5.3 \pm 0.33$

- $3.3 \pm 0.25$

$-56 \pm 0.29$

S. $59 \pm 0.33$

$5.5 .3 \pm 0.21$

5. $92 \pm 0.45$

$8.48 \pm 0.3 .1$ 
One of the things of first interest that will be looked for in this table is the relation of the fluctuation found in different lots of plants of the same species. Particularly is it interesting to compare the conditions of entry $a$ with entry $b$, the first representing Oenothera lamarckiana self-fertilized for sixteen generations, the second the same species which las never been self-fertilized, except as that process may have taken place by natural causes.

One represents 16 generations of artificial selection, the other many generations of natural selection, but in neither case is it probable that the proportionality in the parts of the bud entered into the selection in any specific way. In the nnean values of the several parts, these two lots of plants are founcl to be

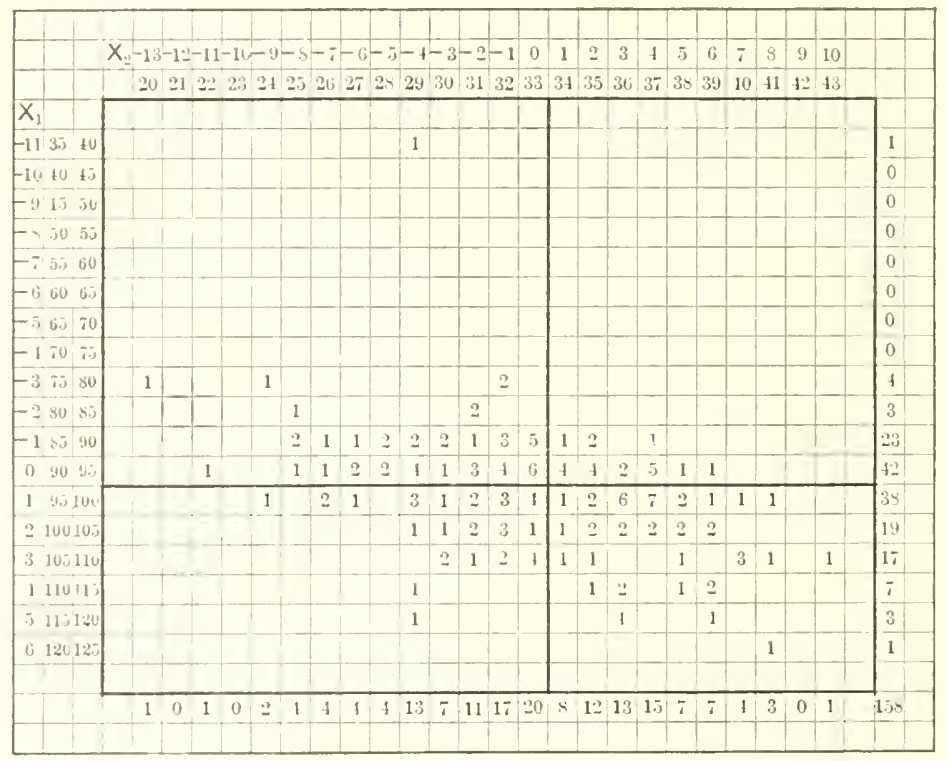

Iis. 10. - Correlation in the buds of Oenothera lamarckiana, No.04129. I.ength of ovary subject, length of hypanthium relative. Coefficient of correlation, $0.421 .5 \pm$ $0.0+11$.

identical only in regard to length of hypanthium and length of cone. Considerable differences are to be seen in length of ovary and thickness of cone, and slight differences in thickness of ovary and of hypanthium. In the standard deviation and coefficient of variability, on the other hand, there is essential identity in every character except in the thickness of the cone, which was significantly more variable in the self-fertilized plants. There are too many possible sources of such difference to nuke any speculation regarding its significance profitable at this time.

When the data in the third entry $\left(c^{\prime}\right)$, is compared with those in the first and fourtl entries, the rery interesting fact develops that in certain charac- 
ters, as thickness of hypanthium and length and thickness of cone, the plants here represented stand intermediate between those of $a$ and $c$, and that the mean length of hypanthium was even less than in either, though it slould have been expected to be as great as that of $a$; in other words, the specimens of $O$.lamarckiana which sprang from a nubrinervis parent had certain characters intermediate between purebred O. lamarckiana and $O$. rubrinervis, and in length of hypanthium they were even less than

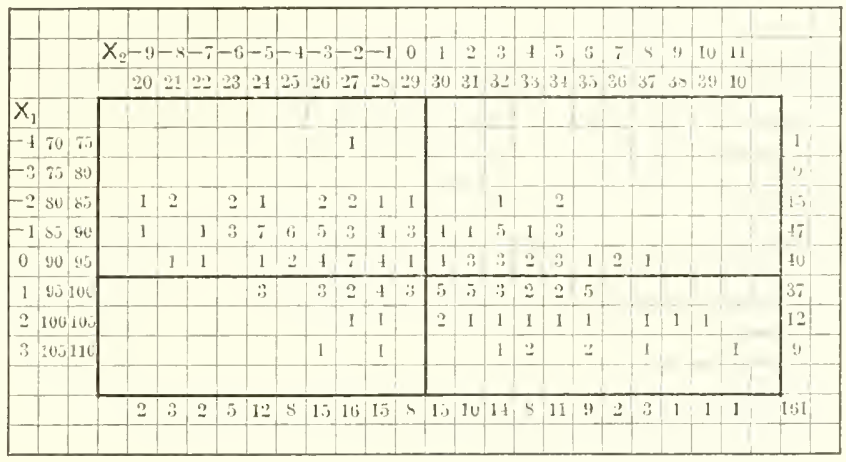

Fig. 11.-Correlation in the buds of Oenothera lamarchiana, No. 04113 Length of ovary subject, length of lypanthium relative. Coefficient of correlation, $0.4719 \pm 0.0413$

those of the latter species. These plants were considered typical Oenothera lamarckiana, not only by myself, but by others who are familiar with that species. Here again, as in the rest of the data presented in this table, the general validity of any conclusion reached may be questioned because of the small amount of data.

Comparison of the entries $c$ and $d$, representing the variation in the buds of two different pedigrees of O. rubrinervis, shows that only in length of hypanthium and thickness of cone were the two lots essentially alike in mean value, the means of the other parts differ-

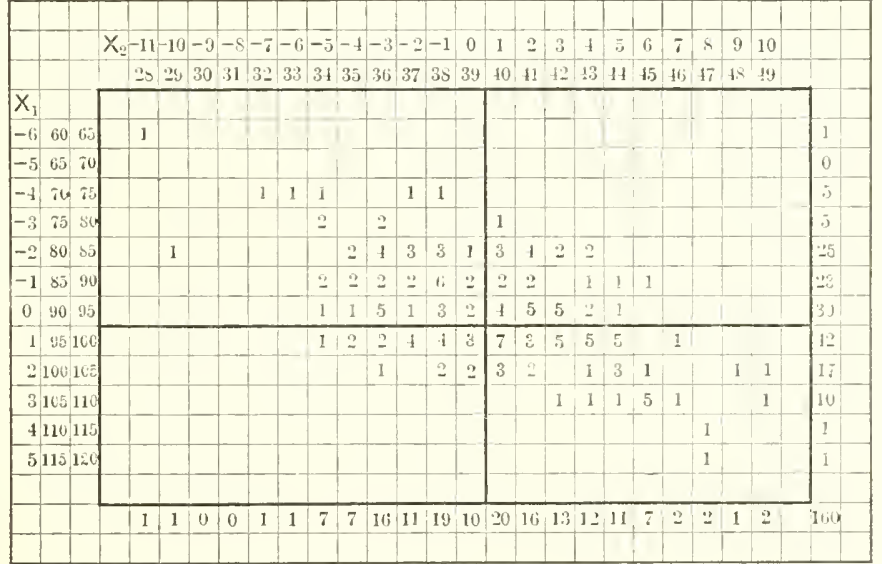

FIG. 12.-Correlation in the buds of Oenothera lamarckiana from Hilversum. Length of ovary subject, length of bud-cone relative. Coefficient of correlation, $0.6340 \pm 0.0319$.

ing fromeach other by more than the sums of the probable errors. In respect to variability, entry $c$ shows considerably greater coefficients in every set of 
measurements than entry $d$. The two lots of plants here compared may be contrasted with respect to their origin and treatment as follows, and some one, several, or all of these contrasted factors will probably satisiactorily account for the difference in variability:

c.

Seed from the New York Botanical Carden.

Of hybrid (?) origin, O. lamarckiana $x$ biennis.

Pollination not guarded.

Seeds sown Feb. I6, 1905 .

Buds collected Sept. 15 to 28 , being the last lialf of the season. d.

Seed from the Botanical Garden of Amsterdam.

From pure-bred O. lamarckana.

Pollination guarded, self-fertilized.

Seeds sown Mar. I 1, 1905.

Buds collected Sept. 30 to Oct. ro, being early in the flowering season.

It remains to compare the three mutants here represented-O. mbrinervis, $O$. gigas, and $O$. lata - with the parent species in regard to mean values of their several characters and the coefficients of their variability. This can

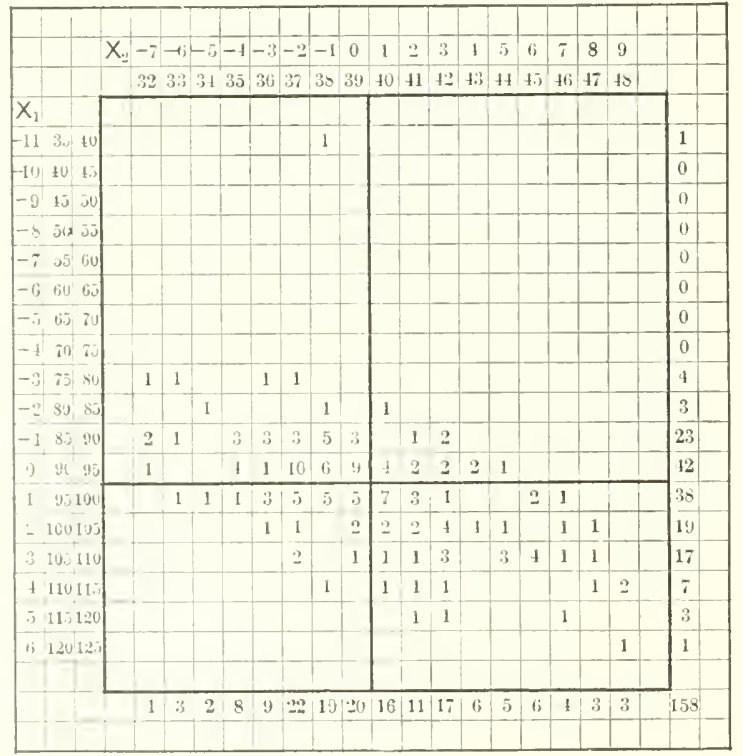

Fig. 13.-Correlation in the buds of Oenothera lamarckiana, No. 04129. I. ength of ovary subject, lengti of bud-eone relative. Coefficient of correlation, $0.5631 \pm 0.0366$. not be done with entire satisfaction because of the inconsistencies in the measurements of plants belonging to different pedigrees in the same species. Such comparison would be just only when the iots of material of all the species liad received identical treatment, and this, as we have scen, has not been true of these. Wherever several lots of plants of a single species have been ised, the average condition of the several lots has been taken for comparison, and as a given amount of deviation in a constant of one value is unfairly compared with a given deviation from a constant of a different value, all the deviations have been reduced to per cents of the equivalent measurement in Oenothera lamarckiana. These values are arranged in the following table in such a way as to allow a comparison 
between the deviation in the mean, $d . M$, and that of the coefficient of variability, $d V$, not only of the characters studied in 1905, but also those of the preceding year derived in the same way.

Deviation of means and variabilities, in per cents of the corresponding values for Ocnothera lamarckiana.

\begin{tabular}{|c|c|c|c|c|c|}
\hline & $d M$ & $d V$ & & $d M$ & $d l^{\prime}$ \\
\hline O. mbrinervis, I904. & & & O. rubrinerizs, 1905 . & & \\
\hline Length of leaf ... & I. $\mathrm{O}_{2}$ & -7.21 & Thickness of ovary. & $s+6$ & II 10 \\
\hline Width of leaf.... & $20 \quad 95$ & 6.91 & Thickness of hypanthium & $1+.8+$ & 0.00 \\
\hline I.eaf ratio ...... & $2+.75$ & 8.08 & Thickness of cone...... & 10.26 & -9.60 \\
\hline Number of branclies... & $10+.59$ & -4.46 & & & \\
\hline Total branch length.... & 172.30 & 116.34 & $\begin{array}{r}\text { O. gigas, } 190.5 . \\
\text { Lengtli of ovary.... }\end{array}$ & () 52 & 1. 03 \\
\hline O. nanella, 1904 . & & & Length of liypanthium... & 20.67 & 57.70 \\
\hline 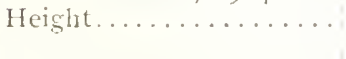 & $7+.28$ & +92.90 & $\begin{array}{l}\text { Length of cune. . . . . . } \\
\text { Tlickness of ovary. . . . }\end{array}$ & $\begin{array}{r}1.54 \\
37.0 .3\end{array}$ & $\begin{array}{l}55.87 \\
+1 \quad 16\end{array}$ \\
\hline O. rubrincrvis, 1905 . & & & Thickness of hypanthium & +2.35 & 83.37 \\
\hline I.ength of leaf ......... & 20.10 & -22.26 & Thickness of cone....... & 29.63 & $1+.2 \mathrm{I}$ \\
\hline Width of leaf.......... & 25.33 & 2.89 & & & \\
\hline Ieaf ratio............ & 6.9 .3 & 16.95 & O. lata, 1905 . & & \\
\hline Height............. & 5.95 & 11.23 & Length of ovary. & 10.53 & 6.53 \\
\hline Number of branches..... & I 5.19 & 3.3 .22 & Length of liypanthium... & 15.06 & 57,70 \\
\hline Total branch length .... & 4.57 & 36.72 & Length of cone. . . . . . . & 22.21 & 7225 \\
\hline Length of ovary ....... & 21.38 & -6.99 & Thickness of ovary...... & IS. I. 3 & -1.3 .7 \\
\hline Length of hypanthium... & $4 \cdot 38$ & -11.07 & Thickness of hypanthium & 13.57 & -5.61 \\
\hline Lengtl of cone........ & 7.66 & -513 & Thickness of cone...... & 13.87 & 8.58 \\
\hline
\end{tabular}

In this table all the deriations which are less than the sum of the probable errors are printed in bold-face figures, and may be left ont of the discussion as having no significance. If the signs of the remaining numbers are taken into account it is founct that 16 of the 30 characters studied showed a greater variability in the mutant than in the parent, while only + were significanty less variable in the mutant. Thus it is found again, as in 1904, that there is a well-marked tendency for the mutant to show a greater variability than its parent, though this relation is far from being absolute. 'The hint then recognized, that the degree of departure from the mean of the parent might be related to the degree of increase in the variability, is also faintly repeated, but is too slight to be now considered of any significance.

The single study in the correlation of characters in $190+$ showed a considerably less correlation in the mutant than in the parent species, and we have already seen in the study of leaf characters above that, though that study was unsatisfactory, such evidence as there is seems to accord with the view then expressed that this represents a general fact. In order to gain further evidence on this point the coefficients of correlation of the parts of the buds were calculated, and all the original measurements are given in the correlation tables appended. 
The coefficients of correlation are as follows:

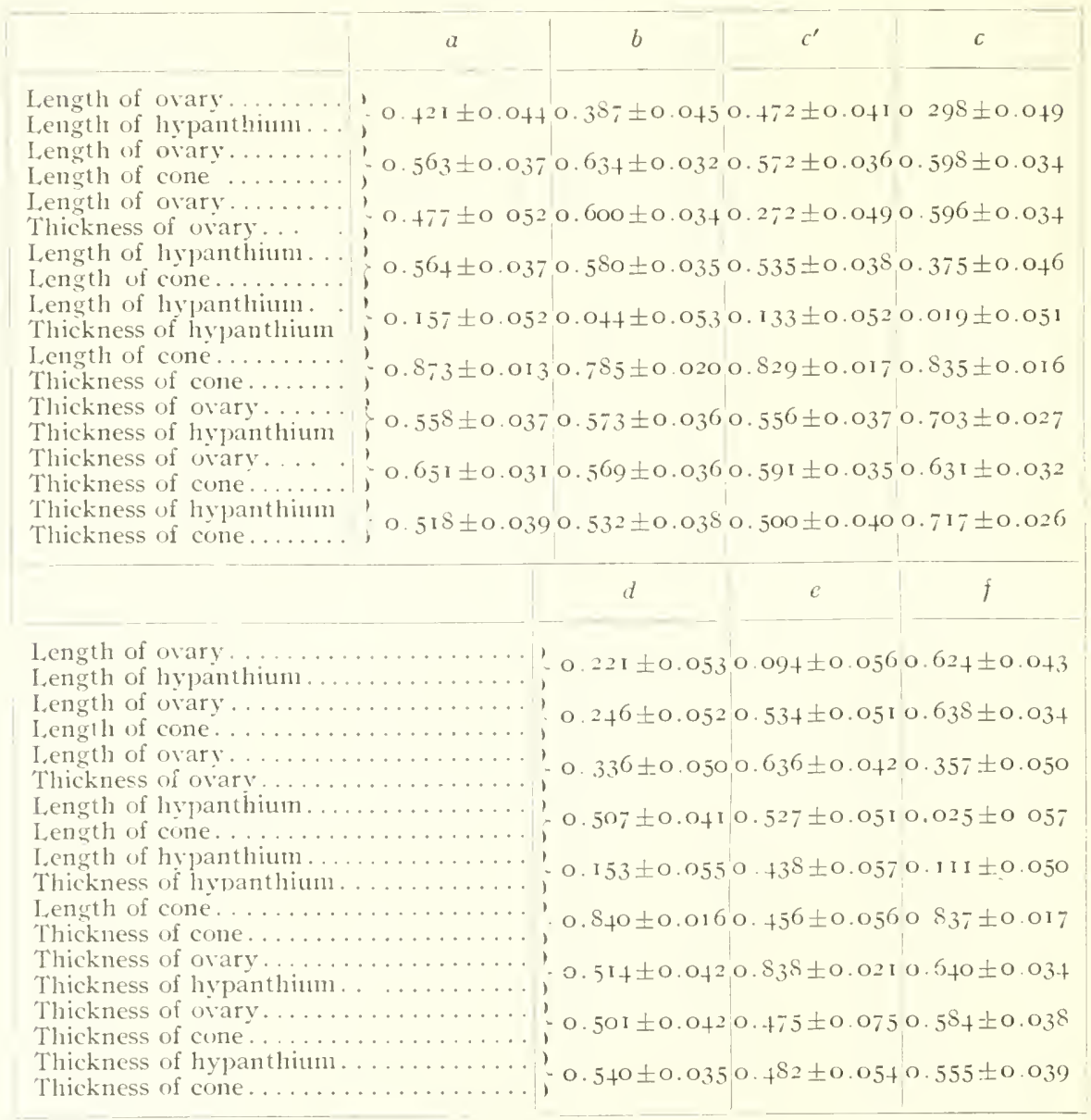

A comparison of the coefficients of correlation in the characters of the sereral mutants with those of the corresponding cliaracters of Oenothera lamarckiana shows that in 14 cases out of 27 thare is a decrease of correlation in the mutant; in 12 instances there is an increase, and in I the correlation remainect the same. These results seem to negative the riew that the characters of the Oenothera mutants are qenerally less closely correlated than those of the parent. However, the differences between the coefficients of the nutants and those of Oinothera lamarckiana are not generally greater than those between the several lots of O. lamarckiana, or between the two lots of O. nubrinervis, and it is evident that the question is still to be considered mudecided, but with the burden of eridence in favor of the view that little or 110 change takes place in the correlation of parts when inutation changes their proportions. 


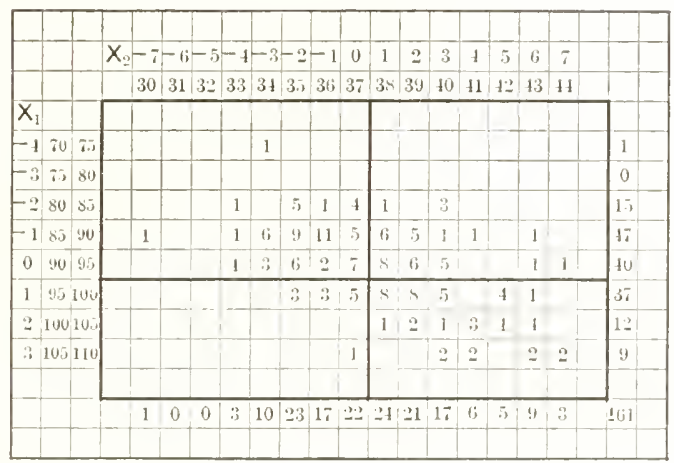

Fig. 14.-Correlation in the buds of Oenothera lamarckiana, No. 04113. Length of ovary subject, length of budcone relative. Coefficient of correlation, $0.5720 \pm 0.0358$.

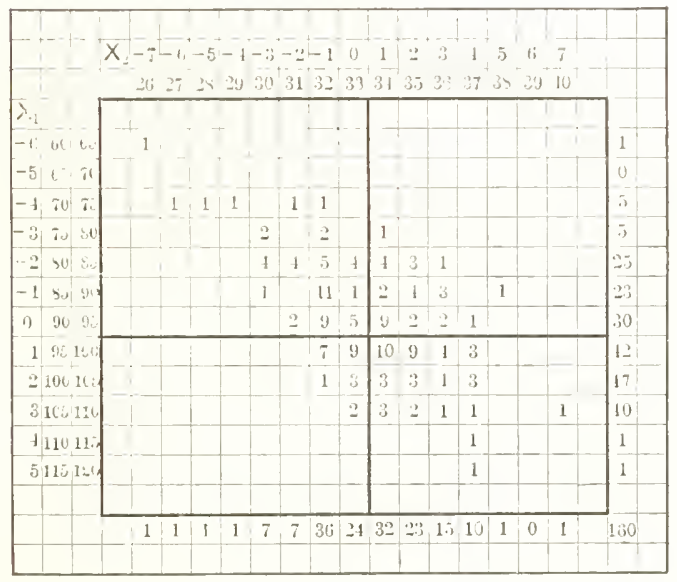

Fig. 15.-Correlation in the buds of Oenothera lamarckiana from Hilversum. Length of ovary subject, thickness of ovary relative. Coefficient of correlation, $0.5997 \pm 0 \quad 03+1$. 


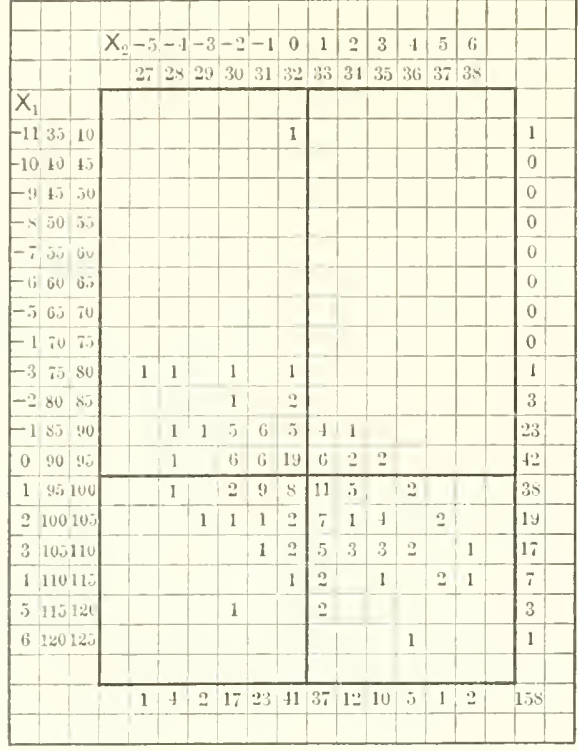

Iis. 16.-Correlation in the buds of Ocnothcra lamarckiana, No. 04129. I.ength of ovary subject, thickness of ovary relative. Coefficient of correlation, $0.4766 \pm 0.0522$.

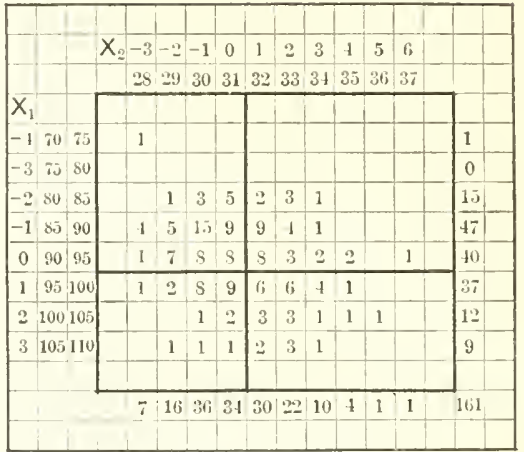

Fig. 17.-Correlation in the buds of Ocnothera lamarckiana, No. 0\$113. Length of ovary subject, thickness of ovary relative. Coefficient of correlation, 0.2724 \pm 0.0492 .

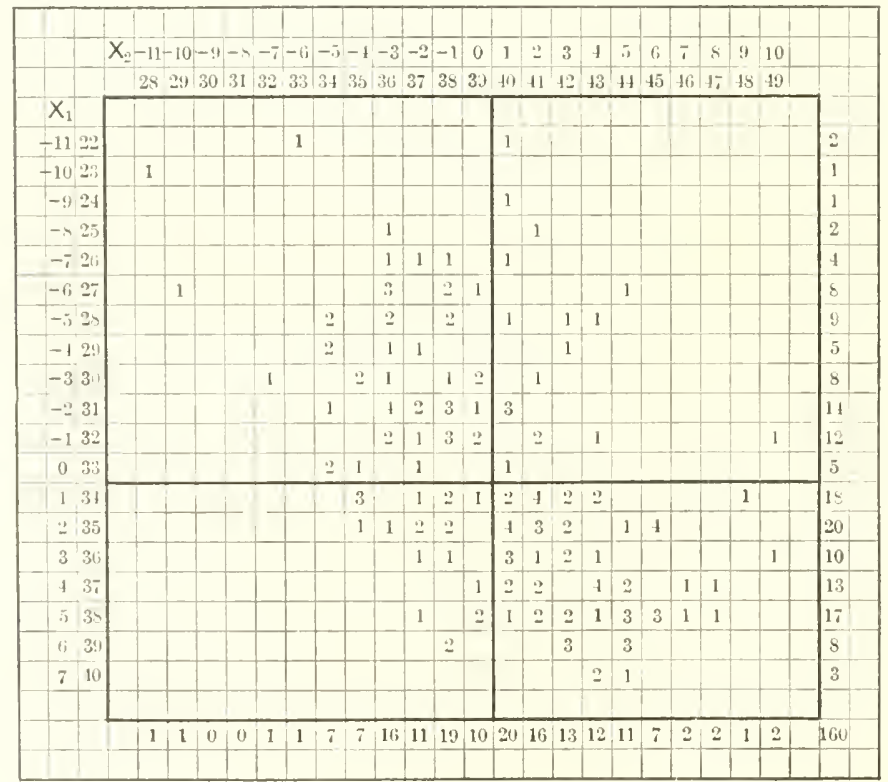

Fis. 18.-Correlation in buds of Oenothera lamarckiana from Hilversum. Length of hypandium subject, length of bud-cone rclative. Coefficient of correlation, $0.5797 \pm 0.0354$. 

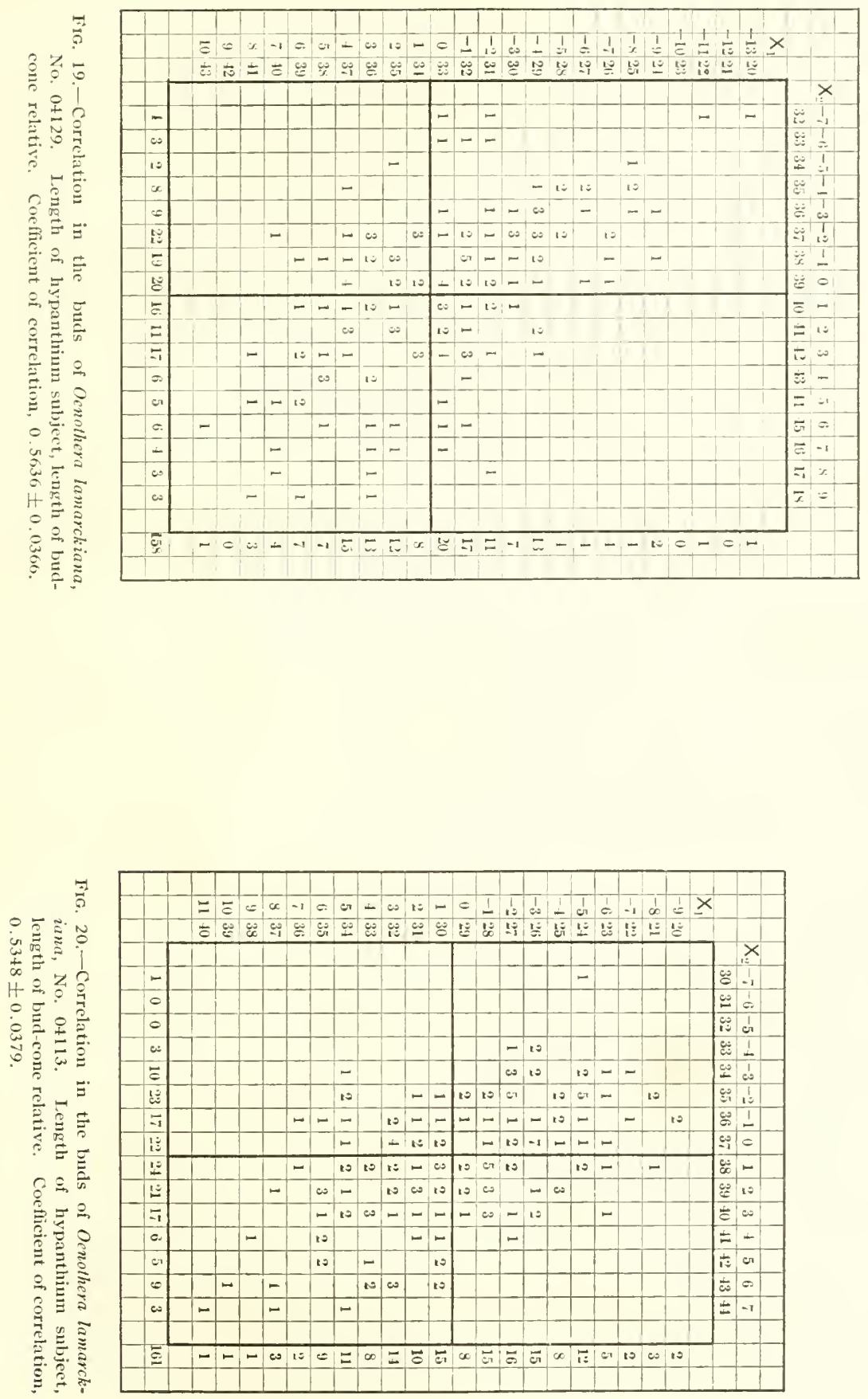

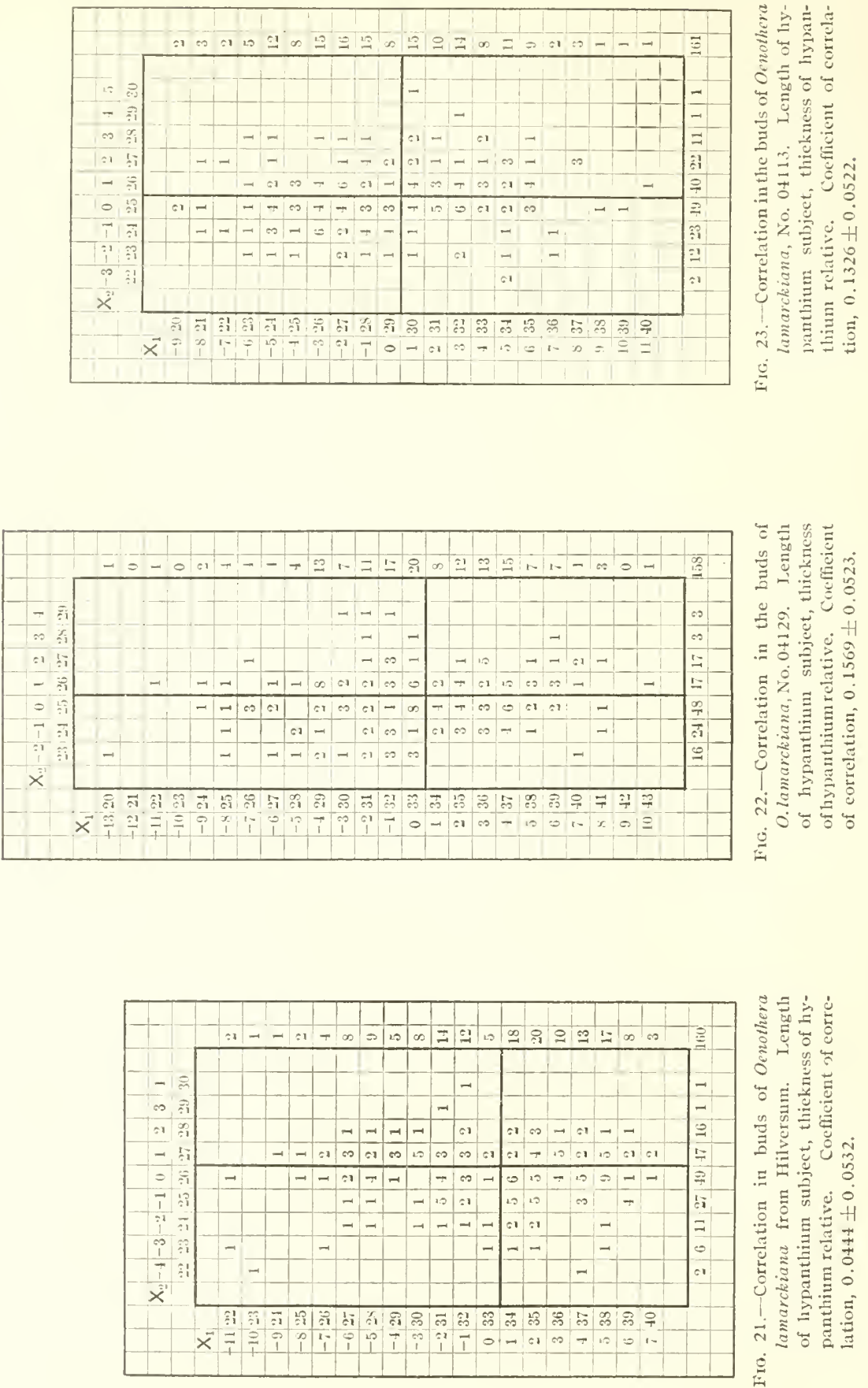


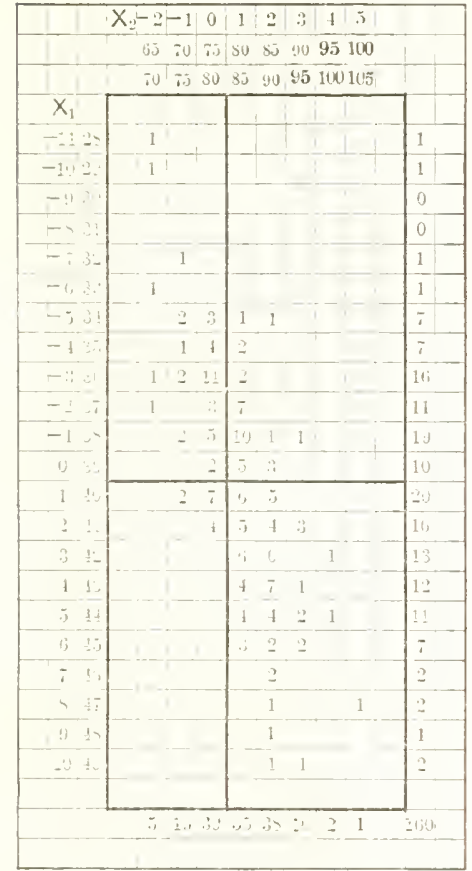

FIG. 24.-Correlationinbuds of O.limarckiana from Hilversum. Length of bulcone subject, thickness of bud-cone relative. Crefficient of correlation, $0.7852+0.0204$

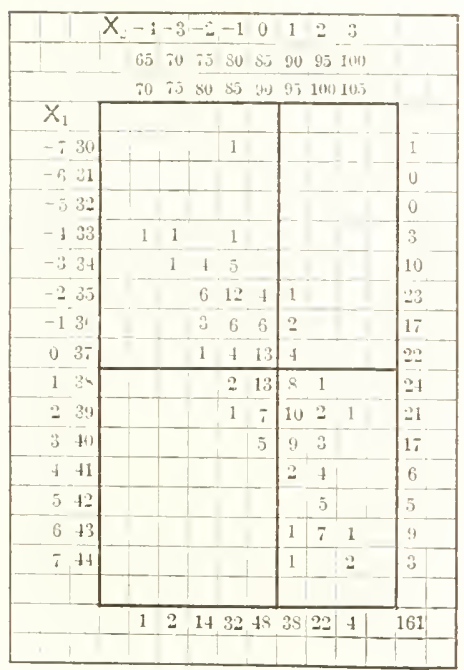

FIG. 26.-Correlation in the bud of Oeno thera lamarckiana, No. $0+113$. Length
of bud-cone subject, thickness of budcone relative. Coefficient of correlation, $0.8289 \pm 0.0166$.

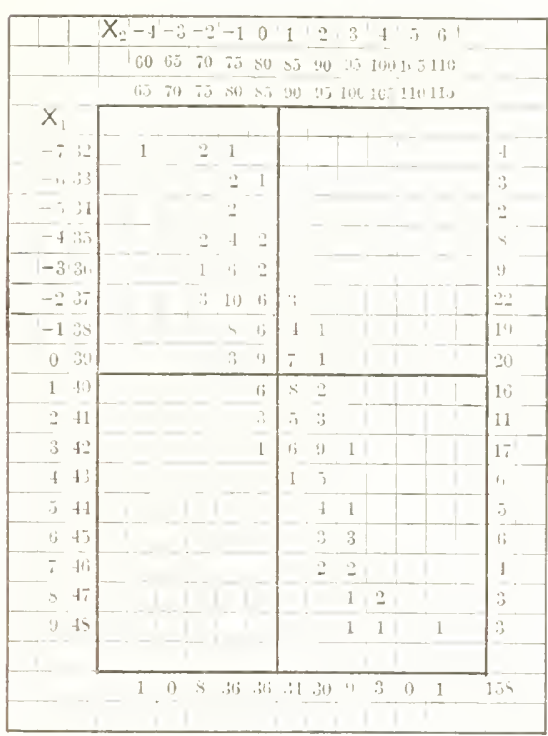

FIG. 25.-Correlation in the louds of Oonothera lamarckama. Nis. 04129. I.ength of bud-cones subject, thickness of bud-cone relative. Coefticient of correlation, $0.8732 \pm 0.0127$.

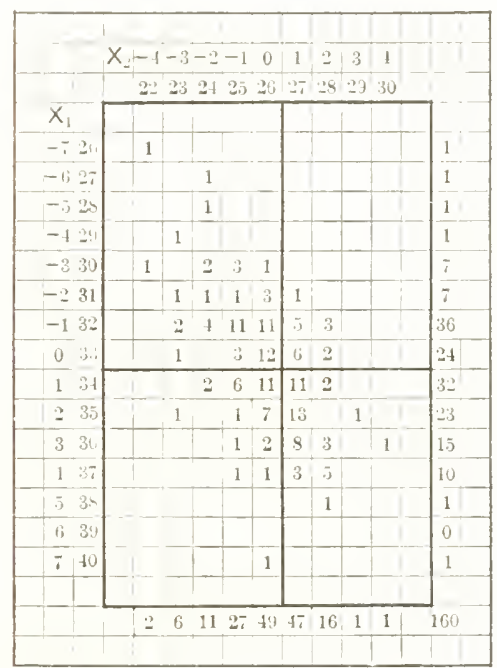

Fig. 27.-Correlation in the buds of Oenothera lamarckiana from Hilversum. Thickness of ovary subject, thickness of hypanthium relative. Coefficient of correlation, 0.5727 $\pm 0.035 \mathrm{~s}$ 


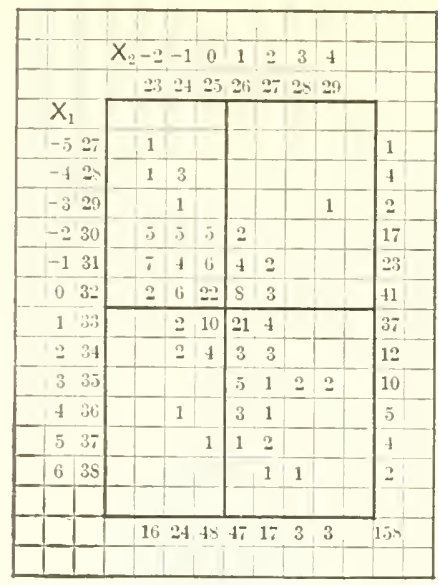

FiG. 2S.-Correlation in the buds of $O$. lamarckiana, 0.4129. Thickness of ovary subject, thickness of hypanthium relative. Coefficient of correlation, $0.5579 \pm 0.0370$.

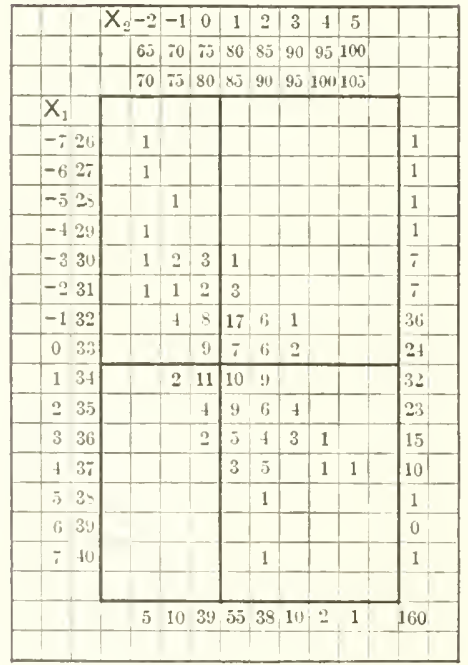

Fig.30.-Correlation in buds of Oenothera lamarckianafrom IIilversum. Thickness of ovary subject, thickuess of budconte relative. Coefficient of correlation, $0.5691 \pm 0.0360$.

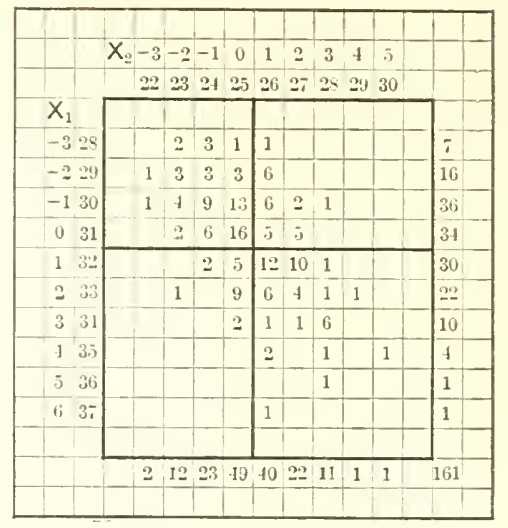

Fig. 29.-Correlation in the buds of Oenothera lamarckiana, No.04113. Thickness of ovary subject, thickness of hypanthium relative. Coefficient of correlation, $0.5565 \pm 0.0367$.

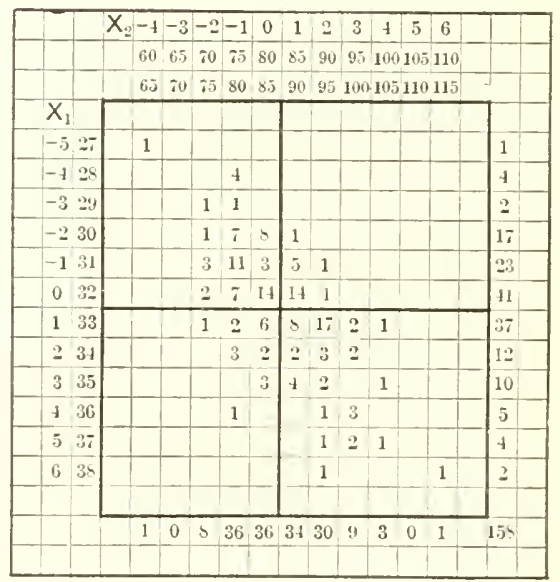

F1G. 31.-Correlation in the buds of Oenothera lamarckiana, No. 04129. Thickness of ovary subject, thichness of bud-cone relative. Coefficient of correlation, $0.6506 \pm 0.0309$. 


\begin{tabular}{|c|c|c|c|c|c|c|c|c|c|c|c|c|}
\hline & & $x_{2}$ & -1. & -8 & $-\varepsilon$ & -1 & 0 & 1 & 2 & 3 & & \\
\hline & & & 65 & i0 & 87 & 80 & 8.j & 90 & & 100 & & \\
\hline & & & ii) & i.j) & 80 & 85 & 90 & ע.J.J & 106 & $1 \cup \bar{\jmath}$ & & \\
\hline \multicolumn{2}{|l|}{$x_{1}$} & & & & & & & & & & & \\
\hline-3 & & & & & 2 & 1 & & 1 & & & 7 & \\
\hline-2 & & & & 2 & 3 & 6 & 5 & & & & 16 & \\
\hline-1 & & & & & $\bar{i}$ & 6 & 12 & 10 & 1 & & 36 & \\
\hline & 31 & & 1 & & & 11 & 10 & 7 & 2 & & 34 & \\
\hline 1 & 32 & & & & 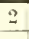 & 2 & 12 & 7 & 7 & & 30 & \\
\hline 2 & 33 & & & & & & 9 & 7 & 5 & 2 & 2 & \\
\hline 3 & 34 & & & & & & & 3 & 6 & 1 & 10 & \\
\hline$i$ & 3.5 & & & & & & 1 & 2 & & 1 & 4 & \\
\hline j. & 36 & & & & & & & & 1 & & 1 & \\
\hline \multirow[t]{3}{*}{6} & 37 & & & & & & & 1 & & & 1 & \\
\hline & & & & & & & & & & & & \\
\hline & & & 11 & 2 & 11 & 32 & 48 & 38 & 22 & 1 & 161 & \\
\hline & & & & & & & & & & & & \\
\hline
\end{tabular}

FIG. 32.-Correlation in buds of $O$ lamarckiana, No.04113. Thickness of ovary subject, thickness of budcone relative. Coefficient of correlation. $0.5910 \pm 0.0346$.

\begin{tabular}{|c|c|c|c|c|c|c|c|c|c|c|c|}
\hline & & & -2 & -1 & 0 & 1 & 2 & 3 & 4 & $j$ & \\
\hline & & & 65 & 70 & 85 & 80 & 85 & 90 & & 100 & \\
\hline & & & 70 & I5 & 80 & 85 & 90 & & & 105 & \\
\hline \multicolumn{12}{|c|}{$X_{1}$} \\
\hline & -422 & & 1 & & 1 & & & & & & 2 \\
\hline & -323 & & 1 & 2 & & 3 & & & & & 6 \\
\hline & -224 & & 3 & 1 & 2 & 1 & 1 & & & & 11 \\
\hline & \begin{tabular}{l|l}
-1 & 25
\end{tabular} & & & 3 & 9 & 12 & 3 & & & & 27 \\
\hline & \begin{tabular}{l|l}
0 & 26 \\
\end{tabular} & & & 1 & 17 & 16 & 10 & 3 & $\cong$ & & 49 \\
\hline & 127 & & & & 10 & 15 & 17 & 51 & & & 17 \\
\hline & 28 & & & & & 6 & 7 & 2 & & 1 & 16 \\
\hline & 399 & & & & & 1 & & & & & 1 \\
\hline \multirow{2}{*}{\multicolumn{2}{|c|}{+30}} & & & & & 1 & & & & & 1 \\
\hline & & & & & & 1 & 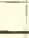 & & & & 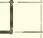 \\
\hline & & & 5 & 10) & 39 & 55 & 38 & & 2 & 1 & 160 \\
\hline & & & & & & & & & & & \\
\hline
\end{tabular}

Fig. 33.-Correlation in buds of $O$. lam arckiana from Hilversum. Thickness of hypanthium subject, thickness of bud-cone relative. Coefficient of correlation, $0.5310=0.0382$

\begin{tabular}{|c|c|c|c|c|c|c|c|c|c|c|c|c|c|c|}
\hline & & $\bar{X}_{2}$ & -1 & -3 & -2 & -1 & 0 & 1 & 2 & 3 & 1 & 5 & 6 & 7 \\
\hline & & & 60 & 6.7 & 70 & $\therefore$ & 85 & 85 & 90 & & 100 & 105 & 110 & \\
\hline & & & 6.5 & iol & 80 & 80 & $8 \bar{j}$ & 90 & & 100 & $10-3$ & 110 & 115 & \\
\hline$X_{1}$ & & & & & & & & & & & & & & \\
\hline-2 & & & 1 & & 2 & 9 & 2 & 2 & & & & & & 16 \\
\hline-1 & 24 & & & & 2 & 9 & 5 & $\bar{j}$ & 3 & & & & & 21 \\
\hline 0 & 25 & & & & 3 & 10 & 15 & 9 & 10 & 1 & & & & 1 \\
\hline 1 & 20 & & & & 1 & 6 & 11 & 15 & 9 & 4 & 1 & & & 17 \\
\hline 2 & 27 & & & & & 1 & 2 & 3 & 6 & 4 & 1 & & & 17. \\
\hline 3 & $2 s$ & & & & & & 1 & & 1 & & & & 1 & 3 \\
\hline 4 & 29 & & & & & 1 & & & 1 & & 1 & & & 3 \\
\hline & & & & & & & & & & & & & & 1 \\
\hline & & & 1 & 0 & 8 & 36 & 36 & 34 & 30 & 9 & 3 & 0 & 1 & 155 \\
\hline & & & & & & & & & & & & & & \\
\hline
\end{tabular}

Fig. 34.-Correlation in the buds of Oenotherd lamarckiana, No. 04129 . Thickness of hypanthium subject, thickness of bud-cone relative. Coefficient of correlation, 0.5180 +0.0393 .

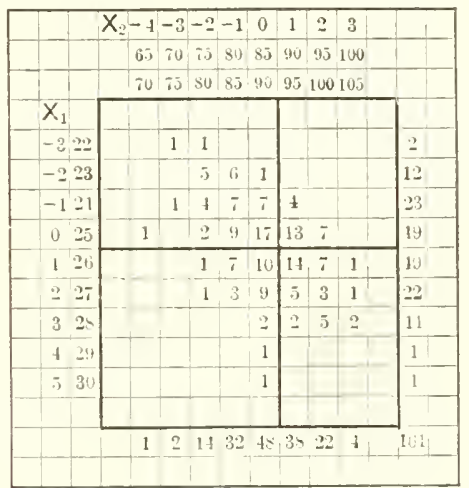

Fig. 35.-Correlation in the buds of $O$. lamarckiana, No. 04113. Thicknes of hypanthium subject, thickness of bud-cone relative. Coefficient of correlation, $0.5005 \pm 0.0398$

\begin{tabular}{|c|c|c|c|c|c|c|c|c|c|c|c|c|c|c|c|c|c|c|c|c|c|c|}
\hline & & & & & & & & & & & & & & & & & & & & & & \\
\hline & & $X$ & -9 & -8 & -7 & -6 & -5 & -4 & -3 & -2 & -1 & 0 & 1 & 2 & 3 & 4 & 5 & 6 & 7 & 8 & 9 & \\
\hline & & & 21 & $\cdots 2$ & 23 & 21 & 25 & 26 & $z$ & 28 & 29 & 30 & 31 & 32 & 33 & 34 & 35 & 36 & 37 & 35 & 39 & \\
\hline$x_{1}$ & d & & & & & & & & & & & 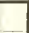 & & & & 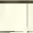 & & & 1 & & & \\
\hline & 8590 & & & 1 & & & & & 2 & 1 & & & 1 & & & & & & & & & 5 \\
\hline & 9095 & & & & 2 & & & 1 & 3 & & 2 & & & 2 & & & & & 1 & & & 11 \\
\hline & 95100 & & & 1 & 1 & 2 & 1 & 1 & 1 & 1 & 1 & 2 & 1 & 2 & & 2 & & & & & & 16 \\
\hline-1 & 100105 & & & & & 1 & 2 & 4 & 1 & 4 & 2 & 4 & 8 & 2 & 1 & 2 & & 1 & 1 & & & 33 \\
\hline 0 & 105110 & & & & & & 1 & & 5 & 2 & 3 & 1 & 3 & 3 & 3 & 1 & 2 & & 1 & 1 & 1 & $2-1$ \\
\hline 1 & 110115 & & 1 & & & & 2 & 1 & 1 & 2 & 1 & 5 & 3 & & 1 & 2 & 2 & 4 & 3 & 1 & 1 & 30 \\
\hline 2 & 115120 & & 1 & & & & 1 & 1 & & & 2 & 1 & 1 & 4 & 1 & 1 & 2 & 1 & & & & 16 \\
\hline & 120125 & & & & & 1 & & & & & 1 & 1 & 2 & 3 & 1 & 1 & 1 & & & & & 11 \\
\hline 1 & 125130 & & & & & & & & & & 1 & 1 & 1 & 2 & & 3 & & 1 & & & & 9 \\
\hline 5 & 130135 & & & & & & 1 & & & & & & & & & & & & & & & 1 \\
\hline & 135140 & & & & & & & & & & & & & & & 1 & & & & & & 1 \\
\hline & & & & & & & & & . & & & & & . & 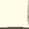 & 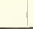 & & 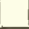 & 1 & & & \\
\hline & & & 2 & 2 & 3 & 4 & 8 & $s$ & 13 & 10 & 13 & 15 & 20 & 18 & 7 & 13 & 7 & $i$ & 6 & 21 & 2 & 160 \\
\hline & & & & & & & & & & & & & & & & & & & & & & \\
\hline
\end{tabular}

Fig. 36.-Correlation in the buds of Oenothera rubrinervis, No. 04113. Length of ovary subject, length of hypanthium relative. Coefficient of correlation, $0.2985 \pm 0.0486$. 
44 MUTATIONS, VARIATIONS, AND RELATIONSHIPS OF THE OENOTHERAS.

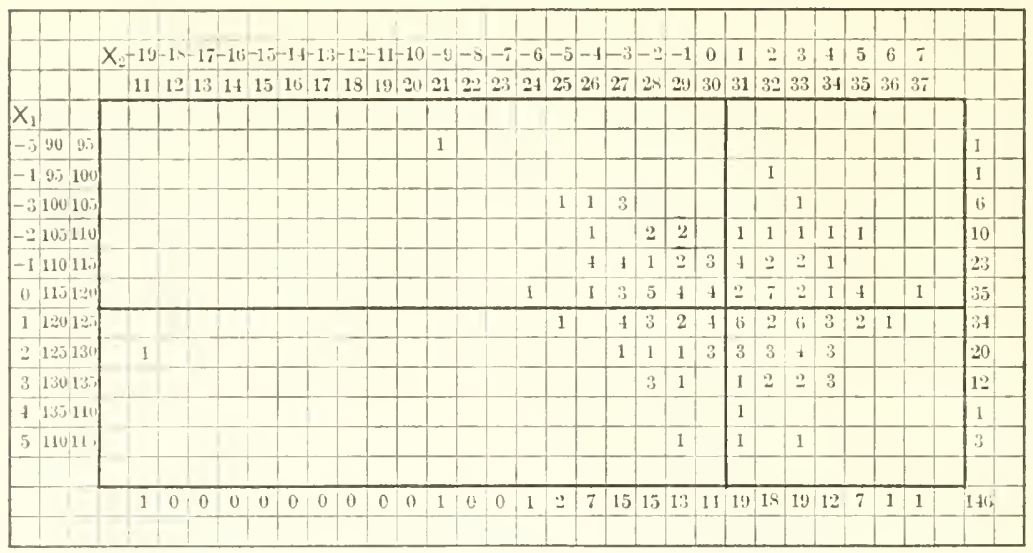

F1G. 37.-Correlation in the buds of Oenothera rubrincris, No."04137. Length of ovary subject, length of hypanthium relative. Coefficient of correlation, $0.2211 \pm 0.0531$.

\begin{tabular}{|c|c|c|c|c|c|c|c|c|c|c|c|c|c|c|c|c|c|c|c|c|c|c|c|c|c|}
\hline & & & & & & & & & & & & & & & & & & & & & & & & & \\
\hline & & & $<-9$ & -4 & $-i$ & $-1 i$ & -5 & -4 & -3 & -2 & -1 & 0 & 1 & $\because$ & 3 & 4 & 5 & ii & 7 & 8 & 91 & 19) 1 & \begin{tabular}{l|l}
11 & 1
\end{tabular} & 12 & \\
\hline & & & 36 & 27 & 28 & 29 & 30 & 31 & 32 & 33 & 31 & 35 & 36 & 371 & $3 s$ & 39 & 10 & 41 & HI & 43 & & 451 & $4 i 1$ & 17 & \\
\hline$x_{1}$ & & & & & & & & & & & & & & & & & & & & & & & & & \\
\hline-1 & 8590 & & & & & & & 2 & 2 & 1 & & & & & & & & & & & & & & & 5 \\
\hline-3 & $\begin{array}{lll}50 & 95\end{array}$ & & & & I & 1 & 1 & 1 & . & 2 & 2 & 2 & & 1 & & & & & & & & & & & 11 \\
\hline-2 & 95100 & & 1 & & 1 & 1 & 2 & 2 & 2 & 2 & 1 & 3 & & 11 & & & & & & & & & & & 16 \\
\hline-11 & 10010 & & & 1 & & & & & 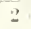 & 3 & 5 & 5 & 7 & 5 & 3 & 2 & & & & & & & & & 33 \\
\hline $\begin{array}{lll}0 & 1\end{array}$ & 105110 & & & & & I & 1 & I & 1 & 1 & 5 & 5 & 4 & :3 & 3 & 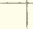 & 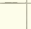 & $\overline{2}$ & & & & & & & 27 \\
\hline 11 & 11011 & & & & & & & 1 & 1 & 1 & 3 & 2 & 6 & 5 & 4 & 2 & 4 & 11 & & & & & & & 30 \\
\hline$\because 1$ & 11512 & & & & & & & & 1 & 2 & & is & 4 & 1 & $\because$ & 1 & & 1 & & 1 & & & & & 10 \\
\hline 31 & 12012 & & & & & & & & & & & & 2 & 2 & 5 & 1 & 1 & & & & & & & & 11 \\
\hline 41 & 12513 & & & & & & & & & & & . & 1 & 1 & & 2 & 1 & & 2 & 1 & & & & 1 & 9 \\
\hline 51 & 13013 & & & & & & & & & & & 1 & & & & & & & & & & & & & 1 \\
\hline 61 & 135110 & & & & & & & & & & & & & & & & & 1 & & & & & & & 1 \\
\hline & & & & & & & & & & & & & & & & & & & & & & & & & \\
\hline & & & 1 & 1 & 2 & 3 & 4 & 7 & 1) & 12 & 16 & 21 & 24 & 19 & $\mid \overrightarrow{17}$ & 8 & (i) & 5 & 2 & 2 & \begin{tabular}{l|l}
0 \\
\end{tabular} & 00 & 0 & 1 & 160 \\
\hline & & & & & & & & & & & & & & & & & & & & & & & & & \\
\hline
\end{tabular}

Fis. 38.-Corrclation in the bud's of Oenothera rubrincrvis. No. 04113. Length of ovary subject, length of bud-cone relative. Coefficient of correlation, $0.5976 \pm 0.0343$.

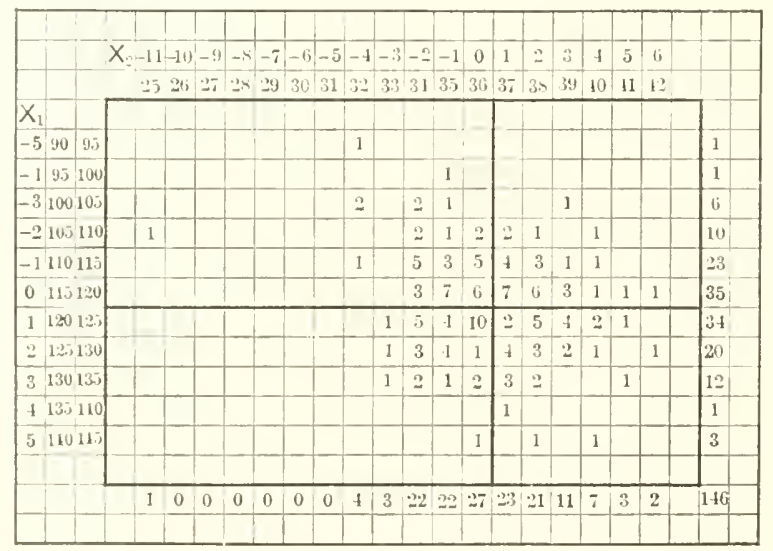

Iig. 39.-Correlation in the buds of Oenothera rubrinervis, No. 04137. Length of ovary subject, length of bud-cone relative. Coefficient of correlation, $0.2464 \pm 0.0524$. 


\begin{tabular}{|c|c|c|c|c|c|c|c|c|c|c|c|c|c|c|c|c|c|}
\hline & & & & & & & & & & & & & & & & & \\
\hline & & $x$ & $2^{-1}$ & -3 & -2 & -1 & 0 & 1 & 2 & 3 & + & 1 & 5 & 6 & 7 & 8 & \\
\hline & & & 25 & 30 & 31 & 32 & 33 & 3 & & 53 & 63 & 7 & 883 & 39 & 10 & 41 . & \\
\hline$X_{1}$ & & & & & & & & & & & & & & & & & \\
\hline-4 & 859 & & 1 & 2 & 1 & 1 & & & & & & & & & & & 5 \\
\hline-3 & 909 & & 1 & 1 & 3 & 4 & & 1 & & & & & 1 & & & & 11 \\
\hline-2 & 9510 & & 2 & 2 & 1 & 7 & 2 & 1 & & 1 & & & & & & & 16 \\
\hline-1 & 16010 & & & 2 & 5 & 6 & 6 & 9 & 6 & 4 & 3 & 2 & & & & & 33 \\
\hline 0 & 10511 & & & 2 & 1 & 11 & 3 & 3 & 3 & 3 & 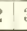 & 3 & & & & & $\because$ \\
\hline 1 & 11011 & & 1 & & 1 & 4 & 7 & 8 & 3 & 3 & & 3 & 1 & & & & 30 \\
\hline 2 & 11512 & & & & & 1 & s & 3 & 5 & 1 & & 1 & 3 & & & & 16 \\
\hline 3 & 12012 & & & & & & & 3 & 1 & 1 & & 1 & 2 & & 2 & 1 & 11 \\
\hline 4 & 12513 & & & & & & 2 & & 1 & & & 2 & 1 & 2 & 1 & & 9 \\
\hline 5 & 13013 & & & & & & & & & 1 & & & & & & & 1 \\
\hline 6 & 13.514 & & & & & & & & & & & 1 & & & & & 1 \\
\hline & & & & & & & & & & & & & 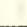 & . & . & & I \\
\hline & & & 5 & 9 & 1 & 3. & & & & & & & $\mathrm{~s}$ & 2 & 3 & I & 160 \\
\hline & & & & & & & & & & & & & & & & & \\
\hline
\end{tabular}

Fig. 40.-Correlation in the buds of Oenothera rubrinervis, No. 04113. Length of ovary subject, thickness of ovary relative. Cuefficient of correlation, $0.5957 \pm 0.0344$.

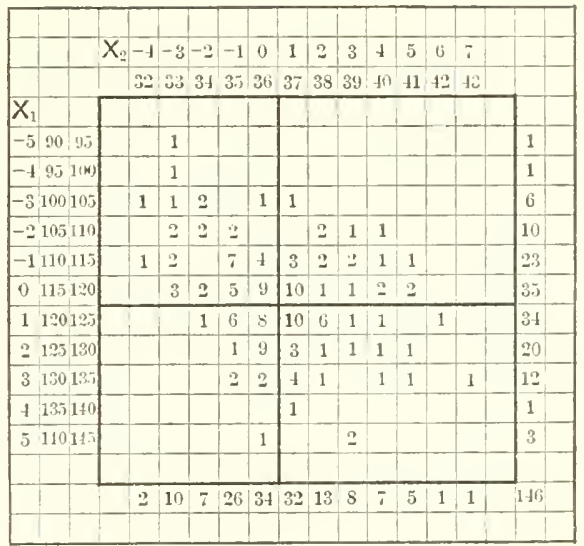

Fig. 41.-Correlation in the buds of $O$. rubrineris, No. 04137. Length of ovary subject, thickness of ovary relative. Coefficient of correlation, $0.3357 \pm 0.0495$.

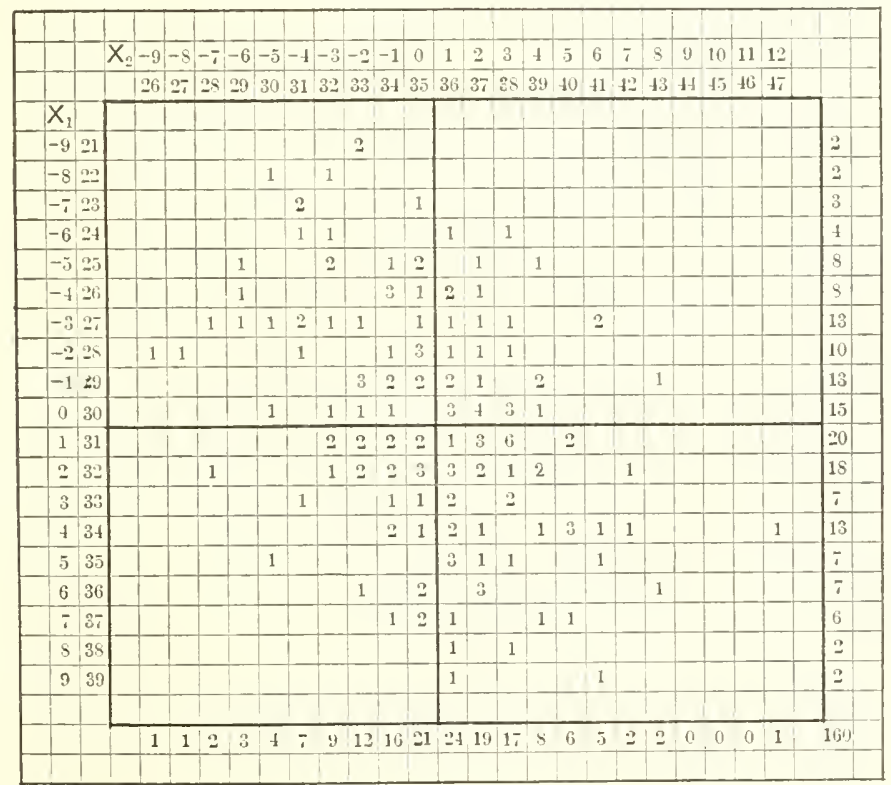

Fig. 42.-Correlation in the buds of Oenethera rubrincris, No. 04113. Length of hypanthium subject, length of bud-cone relative. Cocfficient of correlation, $0.3752 \pm 0.0458$. 
46 MUTATIONS, VARIATIONS, AND RELATIONSHIPS OF THE OENOTHERAS.
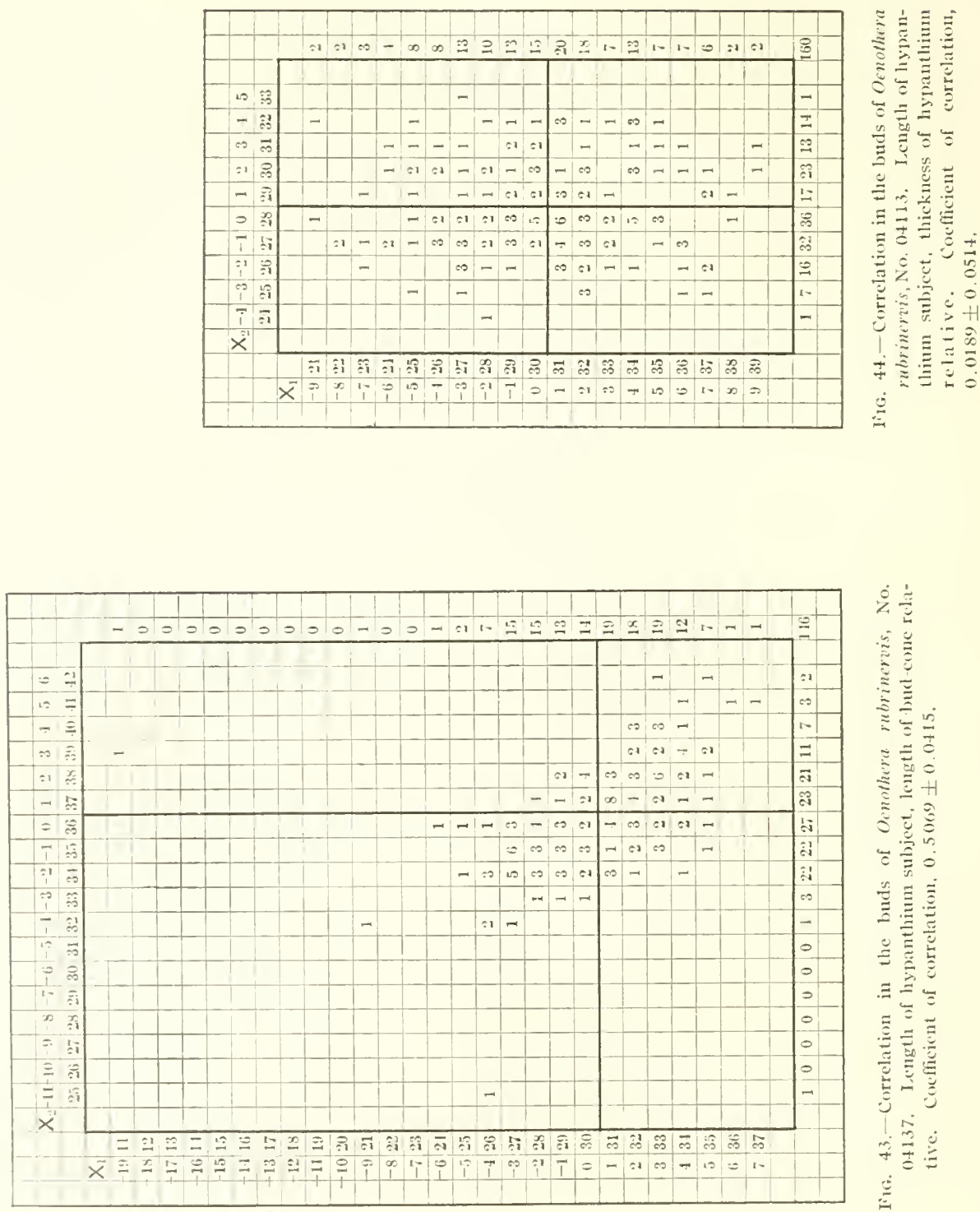
MLTATIONS, VARIATONS, AND RELATIONSHIPS OF THE OENOTHERAS. 47
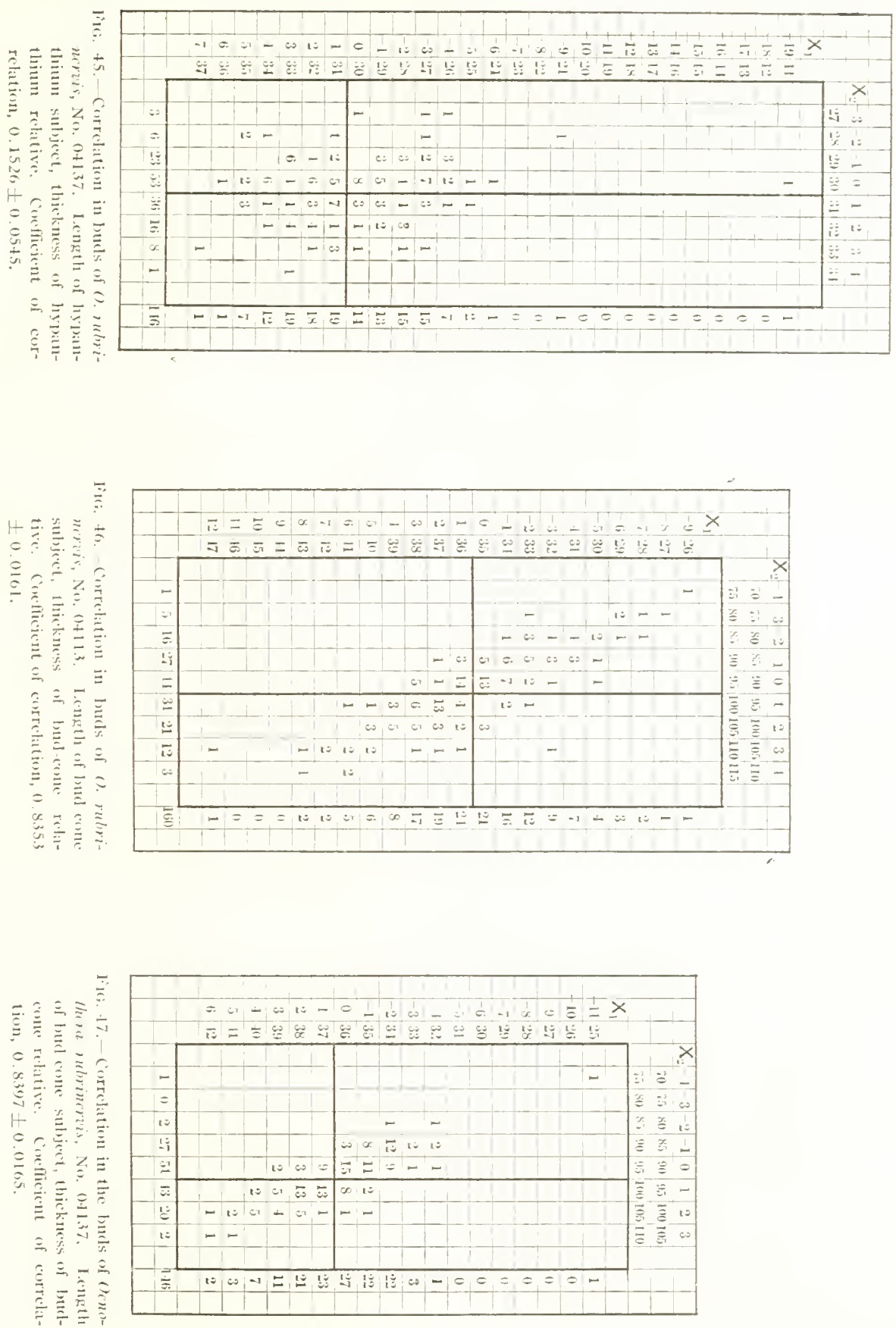


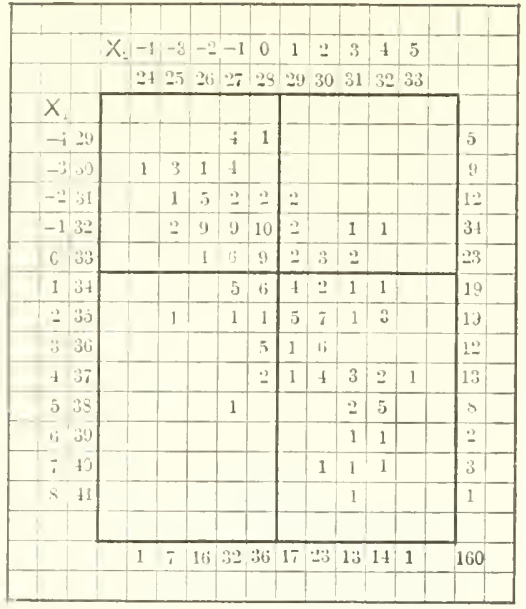

Fig. 48.-Corrclation in the buds of Ocnothera rubrineris, No.04113. Thickness of ovary subject, thickness of hypanthium relative. Coefficient of correlation, $0.7026 \pm 0.0270$.

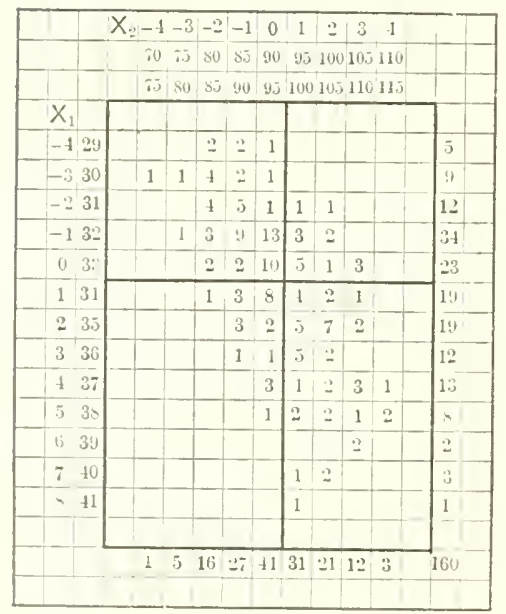

Fig. 50.-Correlation in the buds of Oenothera rubrucrits, No. $0+113$. Thickness of ovary subject, thickness of cone relalive. Cocfficient of correlation, 0.6310 \pm 0.0321 .

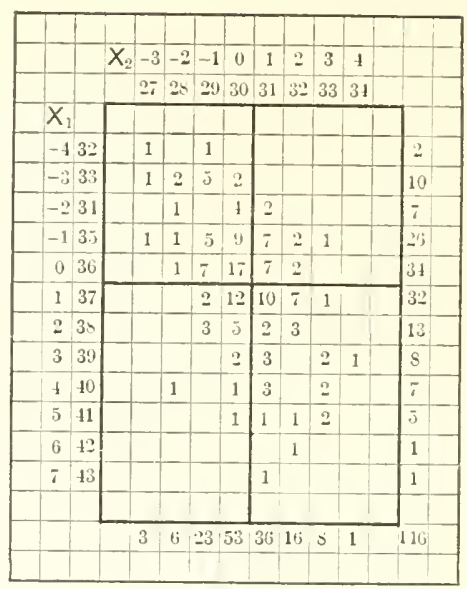

Fig. 49.-Correlation in the buds of Oenothera rubrincris, No. $0+137$. Thickness of ovary subject, thickness of hypanthium relative. Cocfficient of correlation, $0.50+1 \pm 0.0416$.

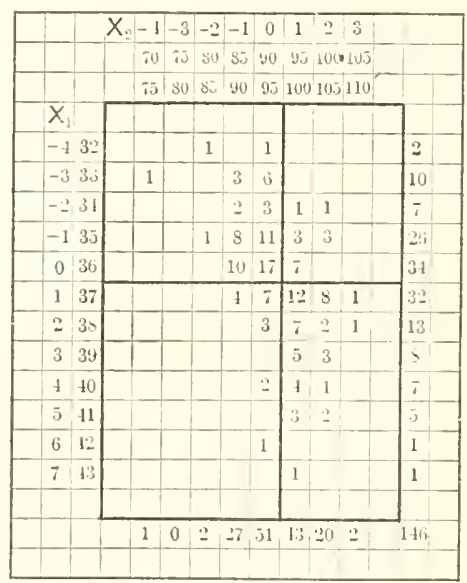

F10. 51.-Correlation in the buds of Oenothera rubrincris, No. 0+137. Thickness of ovary subject, thickness of bud-cone relative. Coefficient of correlation, $0.5006 \pm 0.0+1 \mathrm{~s}$. 


\begin{tabular}{|c|c|c|c|c|c|c|c|c|c|c|c|}
\hline & & $\mathrm{X}_{2}-4$ & -3 & -2 & -1 & 0 & 1 & 2 & 3 & 4 & \\
\hline & & 70 & $\pi$ & 80 & 8.5 & $9 J$ & 951 & 100 & 10.5 & 110 & \\
\hline & & 75 & 80 & 85 & 93 & 95 & 1001 & 105 & 110 & 115 & \\
\hline \multicolumn{12}{|l|}{$\mathrm{X}_{1}$} \\
\hline-4 & & 1 & & & & & & & & & 1 \\
\hline-3 & & & 2 & & 3 & 2 & & & & & 7 \\
\hline-2 & & & 1 & 5 & 5 & 3 & 1 & 1 & & & 26 \\
\hline-1 & & & 1 & 10 & 8 & 12 & 1 & & & & 32 \\
\hline 0 & 25 & & 1 & 1 & 7 & 16 & $\bar{q}$ & 2 & 1 & & $\overline{36}$ \\
\hline 1 & 24 & & & & 3 & 2 & ij & $\bar{j}$ & 1 & & 17 \\
\hline 2 & 30 & & & & & 5 & 9 & 6 & 3 & & 23 \\
\hline 3 & 31 & & & & & 4 & 3 & 3 & 2 & 1 & 13 \\
\hline 4 & 32 & & & & 1 & & 3 & 1 & 4 & 2 & 14 \\
\hline \multirow[t]{3}{*}{5} & 33 & & & & & & & & 1 & & 1 \\
\hline & & & & & & & & & & & \\
\hline & & 1 & 5 & 16 & 27 & 41 & 31 & 21 & 12 & 3 & 160 \\
\hline & & & & & & & & & & & \\
\hline
\end{tabular}

Fro. 52.-Correlation in buds of 0 nubrineris, No. 04113. Thickness of hvpanthium subject, thickness of bud-cone relative. Coefficient of correlation, $0.7170 \pm 0.0259$.

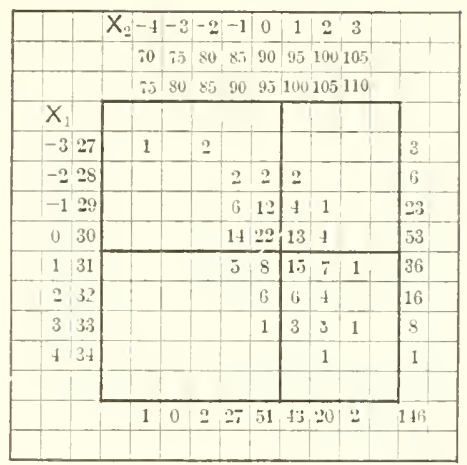

FIG. 53.-Correlation in the buds of O. rubrineris, No. 04137 . Thickness of hypanthium subject, thichness of bud-cone relative. Coefficient of correlation, $0.5397 \pm 0.0354$.

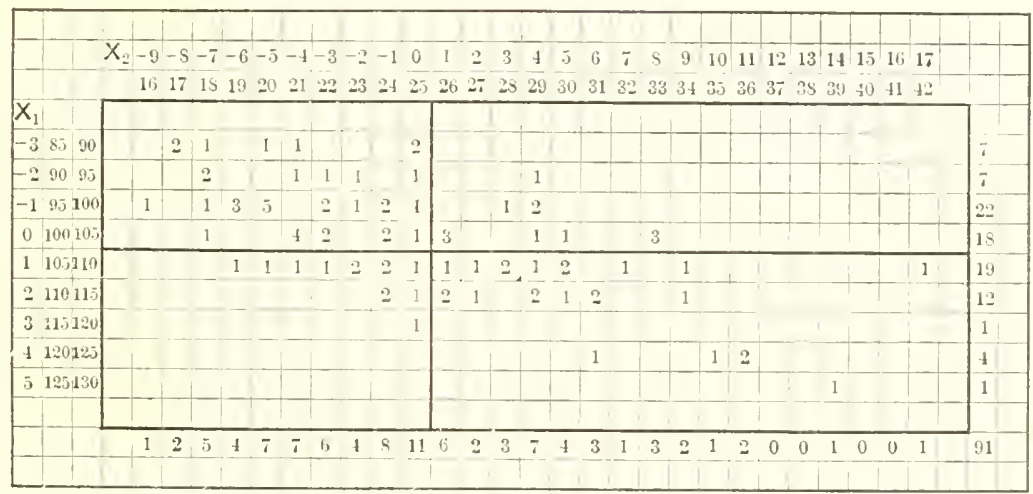

Fig. 54.-Correlaiion in the buds of Oenothera gigas. Length of ovary subject, length of hypanthium relative. Coefficient of correlation, $0.6237+3.0432$.

\begin{tabular}{|c|c|c|c|c|c|c|c|c|c|c|c|c|c|c|c|c|c|c|c|c|c|c|c|c|}
\hline & & & & & & & ? & & & $?$ & & & & & & & & & & & & & & \\
\hline & 1 & & & -5 & -7 & -1 & $i-3$ & -4 & -3 & -2 & -1 & 0 & 1 & 2 & 3 & 4 & 5 & 6 & $T$ & 8 & 9 & 10 & 11 & \\
\hline & & & 31) & 31 & 32 & 33 & 34 & 35 & 36 & 37 & $3 s$ & 39 & 40 & 41 & 12 & 43 & 4 & 44 & 46 & 47 & 10 & $4 !$ & 30 & \\
\hline & $X_{1}$ & & & & & & 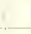 & & & & & & & & & & & & & & & & & \\
\hline-3 & 8590 & & & & & 2 & 1 & & & & & & & & & 1 & & 1 & & & & & & 7 \\
\hline-2 & $90 \quad 95$ & & 1 & & & 1 & 1 & 3 & 1 & & & & & & & & & & & & & & & 7 \\
\hline-1 & 93100 & & & & 1 & 1 & 4 & 2 & 2 & 3 & 2 & 1 & 1 & & 1 & 1 & 2 & & & 1 & & & & $\approx 2$ \\
\hline 0 & 100105 & & & & 1 & & & 2 & 1 & 1 & 3 & 1 & 1 & 1 & 2 & 2 & & 1 & 1 & & & 1 & & 18 \\
\hline 1 & 105110 & & & & 1 & & & 1 & 2 & 1 & 2 & 1 & 1 & 2 & 1 & 2 & & 2 & & 1 & & 1 & 1 & 19 \\
\hline 2 & 110115 & & & & & & & 2 & 1 & & 2 & 1 & 1 & & & 1 & 1 & 1 & 1 & & & 1 & & 12 \\
\hline 3 & 115120 & & & & & & & & & & & & & & & & & & & & & & 1 & 1 \\
\hline 4 & 120125 & & & & & & & & & & & & & & & & & 1 & 1 & & 1 & 1 & & 4 \\
\hline 5 & 125130 & & & & & & & & & & & & & & & & & & & & 1 & & & 1 \\
\hline & & & & & & & & & & & & & & & & & & & & & & & & \\
\hline & & & 1 & 0 & 3 & 1 & 6 & 12 & 7 & 5 & 9 & 4 & 4 & 3 & 4 & 7 & 3 & 6 & 3 & 2 & 2 & 4 & 12 & 91 \\
\hline & & & & & & & & & & & & & & & & & & & & & & & & 1 \\
\hline
\end{tabular}

Fig. 55.-Correlation in the buds of $O$. gigas. Length of ovary subject, length of bud-cone relative. Coefficient of correlation, $0.5338 \pm 0.0506$. 


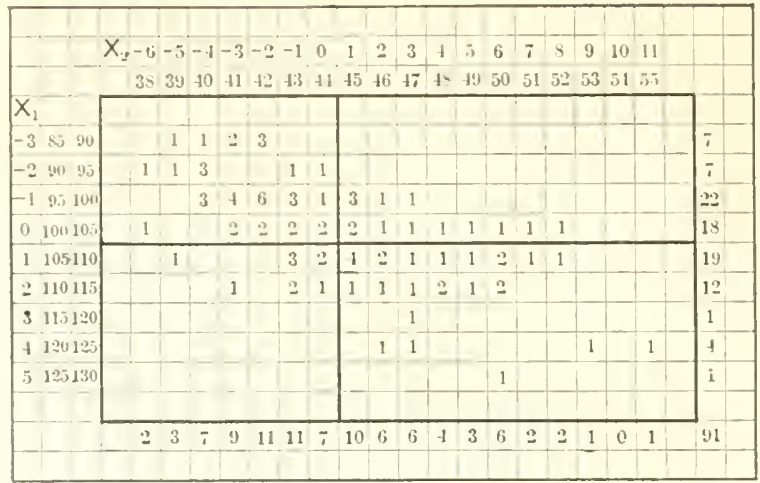

Fig. 56.-Correlation in the buds of Oenothera gigas. Length of ovary subject, thickness of ovary relative. Coefficient of correlation, $0.6360 \pm 0.0421$.

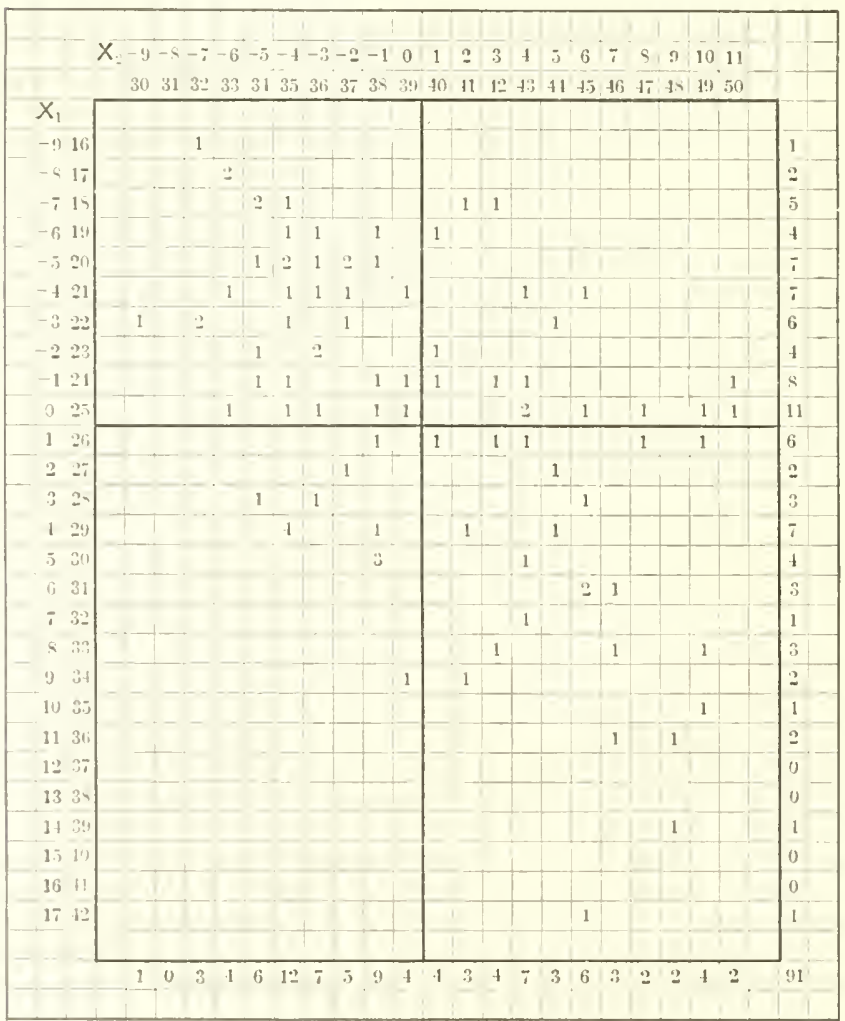

I'1G 57.-Correlation in the buds of Oenothera gigas, Length of hypanthium subject, length of budi-cone relative. Coefficient of correlation, 0.5273 \pm 0.0510 . 
MLTATIONS, VARITIONS, AND RELATHNSHISS OF THE OLNOTHLRAS. 5 I
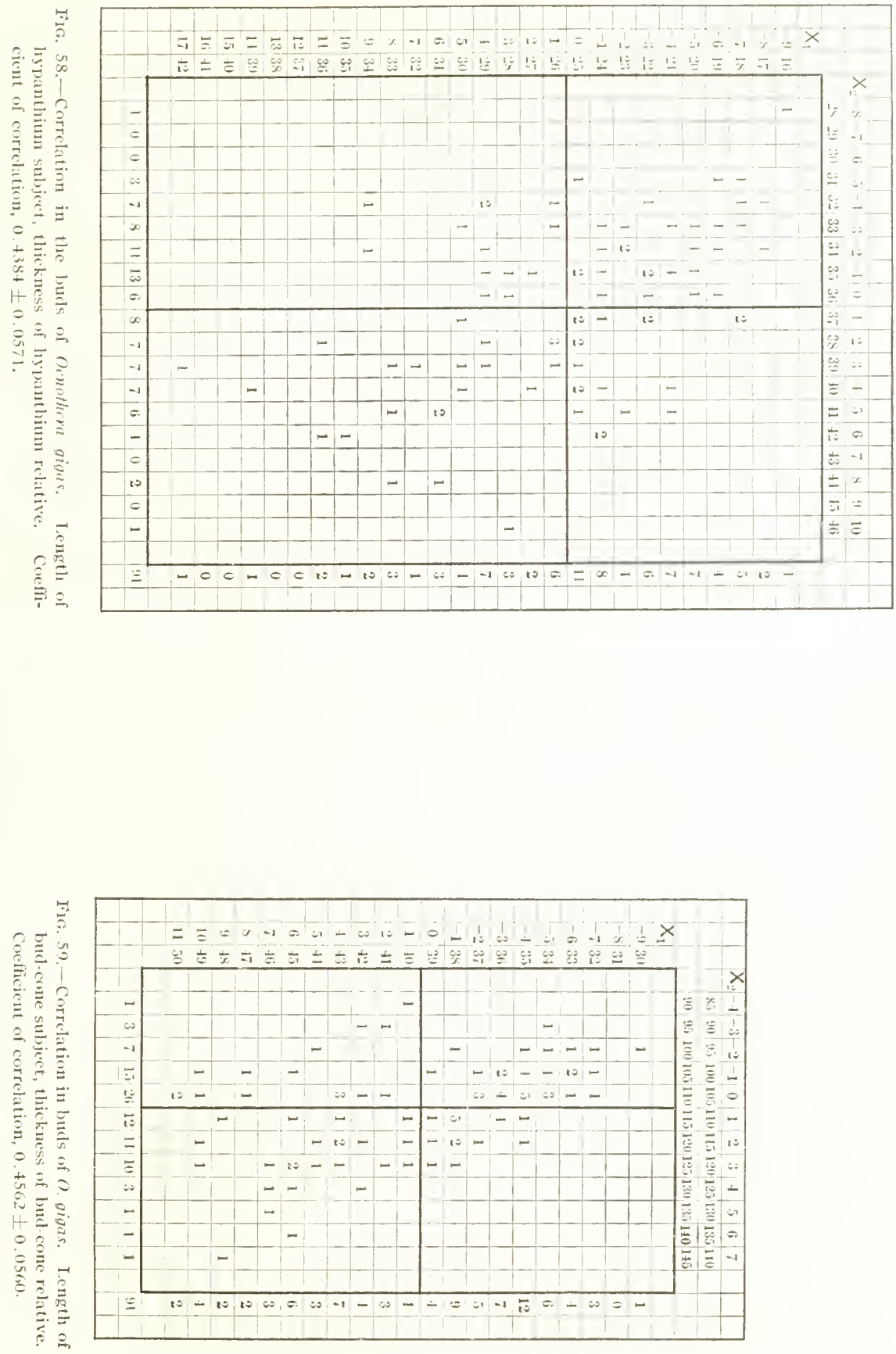


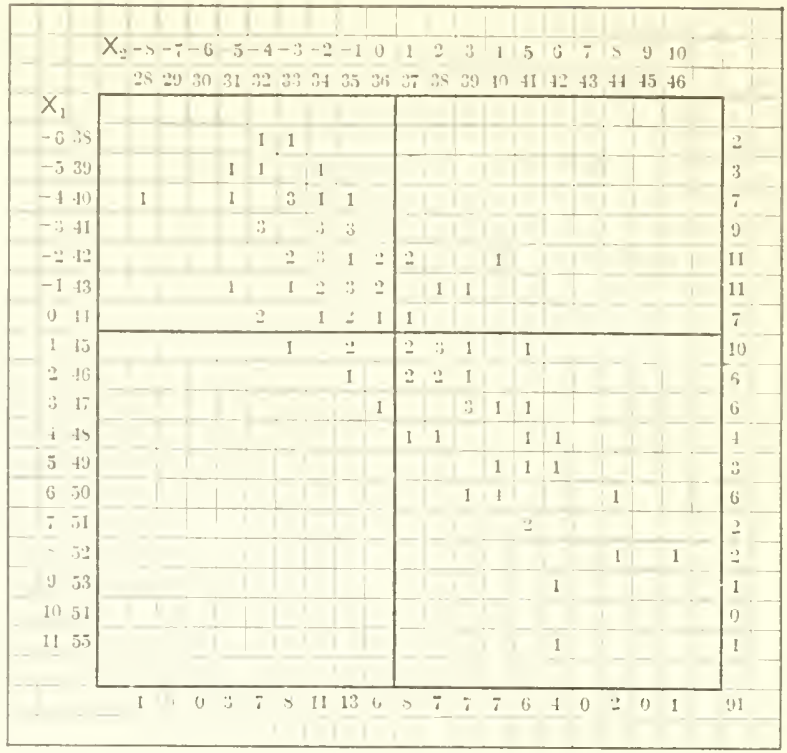

Fig. 60.-Correlation in the buds of Oenothera gigas. Thickness of ovary subject, thickness of liypanthium relative. Coefficient of correlation, $0.8385 \pm 0.0210$.

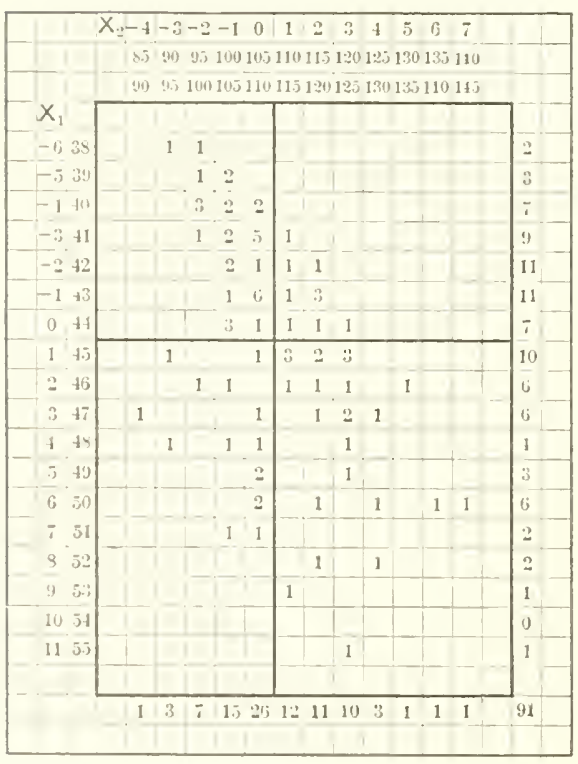

Fig. 61.-Correlation in the buds of Oenothera gigas. 'Thickness of ovary' subject, thickness of bud-cone relitive. Coeflicient of correlation, $0.4750 \pm$ $0.07+7$.

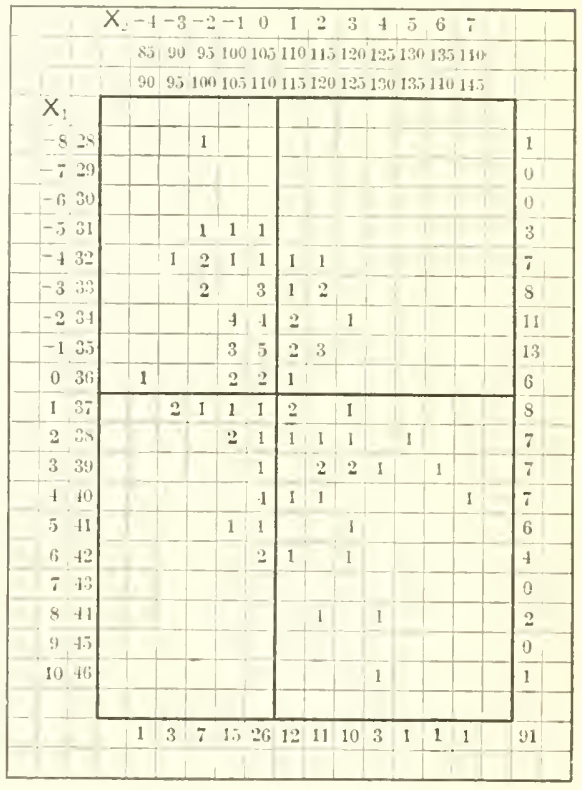

Fis. 62.-Correlation in the buds of Oenothera gigas. Thickness of liypanthium subject, thickness of bud-cone relative. Coefficient of correlation, $0.4822 \pm 0.05+3$. 


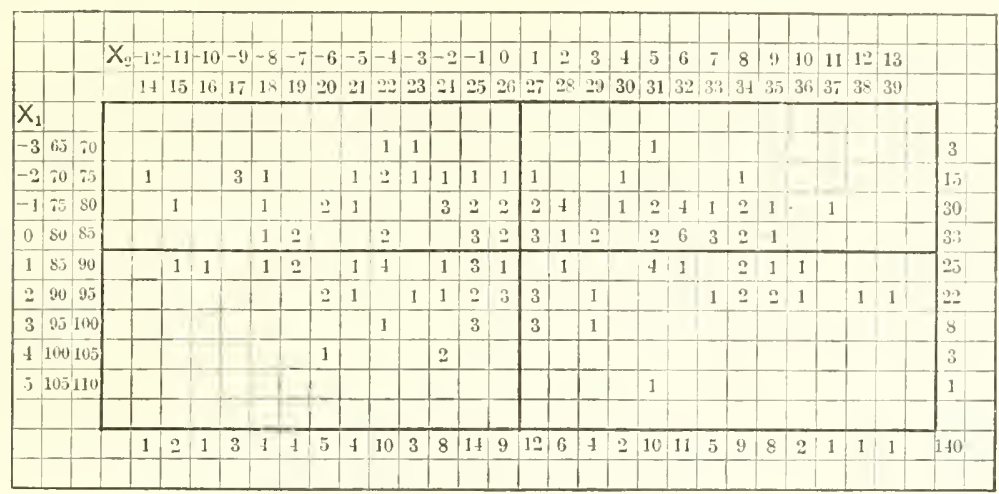

Fig. 63.-Correlation in the buds of Oenothera lata. Length of ovary subject, length of hypanthium rclative. Coefficient of correlation, $0.0944 \pm 0.0565$.

\begin{tabular}{|c|c|c|c|c|c|c|c|c|c|c|c|c|c|c|c|c|c|c|c|c|c|c|c|c|c|}
\hline & & & & & & & & & & & & & & & & & & & & & & & & & \\
\hline & & & $X_{2}-11$ & $1-1$ & $9-9$ & -5 & -7 & -6 & -5 & -1 & -3 & -2 & -1 & 0 & 1 & 2 & 3 & 4 & 5 & 6 & 7 & 8 & 9 & 10 & \\
\hline & & & $1:$ & 412 & 31 & 22 & 23 & 24 & 25 & 26 & 27 & 26 & 29 & 30 & 31 & 32 & 33 & 31 & 3.7 & 36 & $3 \pi$ & 28 & 39 & I1 & \\
\hline $\mathrm{X}_{1}$ & & & & & & & & & & & & & & & & & & & & & & & & & \\
\hline-3 & (6) 7 & & 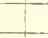 & & & & $\because$ & & & & 1 & & & & & & & & & & & & & & 3 \\
\hline$\because 2$ & (1) & & 1 & & & & & 2 & 2 & 4 & 2 & 1 & & & 2 & & 1 & & & & & & & & 1.5 \\
\hline-1 & 758 & & & & & & 1 & $\simeq$ & 2 & 3 & 3 & 3 & 5 & 2 & 4 & & 4 & & 1 & & 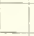 & & & & 31) \\
\hline 0 & $80 \mathrm{~s}$ & & & & & 1 & 1 & 2 & & 2 & 5 & ; & 3 & 6 & & & 1 & & 1 & 1 & & & 1 & & 39 \\
\hline 1 & \begin{tabular}{|l|l}
85 & 90 \\
\end{tabular} & & & & & & & & & & 1 & 4 & 1 & 1 & 4 & 5 & 2 & 1 & 3 & & 2 & & & 1 & $=2$ \\
\hline 2 & \begin{tabular}{|l|l}
90 & 8 \\
\end{tabular} & & & & & & & & & 2 & 2 & & 2 & & & i) & 3 & 4 & 1 & 1 & & & 2 & & 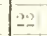 \\
\hline 3 & 9510 & & & & & & & & & & & & & & & & & & & ? & $\because$ & 3 & 1 & & , \\
\hline 4 & 10010 & & & & & & & & & & & & & & & 1 & & & 1 & & 1 & & & & 3 \\
\hline 5 & 10.511 & & & & & & & & & & & & & & & & & & 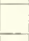 & & & 1 & & & 1 \\
\hline & & & & 1 & & & & & 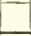 & & & 1 & 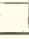 & & & 1 & & & 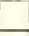 & & & 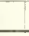 & 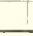 & 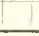 & 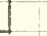 \\
\hline & & & 1 & 0 & $\overline{0}$ & 1 & 4 & 6 & 4 & 11 & 11 & 14 & 11 & 9 & 10) & & 14 & $\overline{5}$ & 7 & 4 & 5 & 4 & 4 & $i$ & $1+i)$ \\
\hline & & & & & & & & & & & & & & & & & & & & & & & & & \\
\hline
\end{tabular}

Fig. 64.-Correlation in the buds of Ofnothera lata. Length of ovary subject, length of bud-cone relative. Coefficient of correlation, $0.6382 \pm 0.0338$.

\begin{tabular}{|c|c|c|c|c|c|c|c|c|c|c|c|c|c|c|c|}
\hline & & & & & & & & & & & & & & & \\
\hline & & & $X_{2}$ & -1 & -3 & -2 & -1 & 0 & 1 & 2 & 3 & 1 & 5 & 6 & \\
\hline & & & & 34 & 35 & 36 & $3 \pi$ & 38 & 34 & 10 & 11 & 42 & 43 & 14 & \\
\hline \multicolumn{16}{|l|}{$X_{1}$} \\
\hline-3 & 65 & 70 & & 1 & & 2 & & . & & . & & 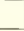 & & & 3 \\
\hline-2 & io & 75 & & & 2 & 5 & 3 & 2 & 2 & 1 & & . & & & 15 \\
\hline-1 & 75 & 80 & & & & 8 & $\mathrm{~s}$ & 4 & 2 & 4 & 3 & 1 & & & 30 \\
\hline 0 & 80 & 8.5 & & & 1 & 5 & 5 & 4 & 9 & 6 & 1 & 1 & 1 & & 33 \\
\hline 1 & $5 \overline{3}$ & 90 & & 1 & 1 & 1 & 4 & 7 & 5 & 8 & 2 & 1 & . & & 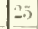 \\
\hline 2 & 90 & & & & 2 & 3 & 2 & $t$ & 1 & 3 & 2 & 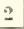 & & 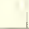 & $\approx$ \\
\hline 3 & 93 & & & & & & & 1 & 2 & 2 & 2 & & & 1 & 5 \\
\hline 4 & 160 & & & & & & & & 2 & 1 & & & & & 3 \\
\hline \multirow{4}{*}{\multicolumn{2}{|c|}{510}} & & & & & & & & & 1 & & & & & 1 \\
\hline & & & & & & & & & & & & & & & \\
\hline & & & & 2 & $\underline{6}$ & 24 & 22 & 22 & $=6$ & 21 & 10 & 5 & 1 & 1 & 110 \\
\hline & & & & & & & & & & & & & & & \\
\hline
\end{tabular}

Fio. 65.-Correlation in the buds of Oenothera lata. Length of ovary subject, thickness of ovary relative. Coefficient of correlation, $0.3568 \pm 0.0497$. 

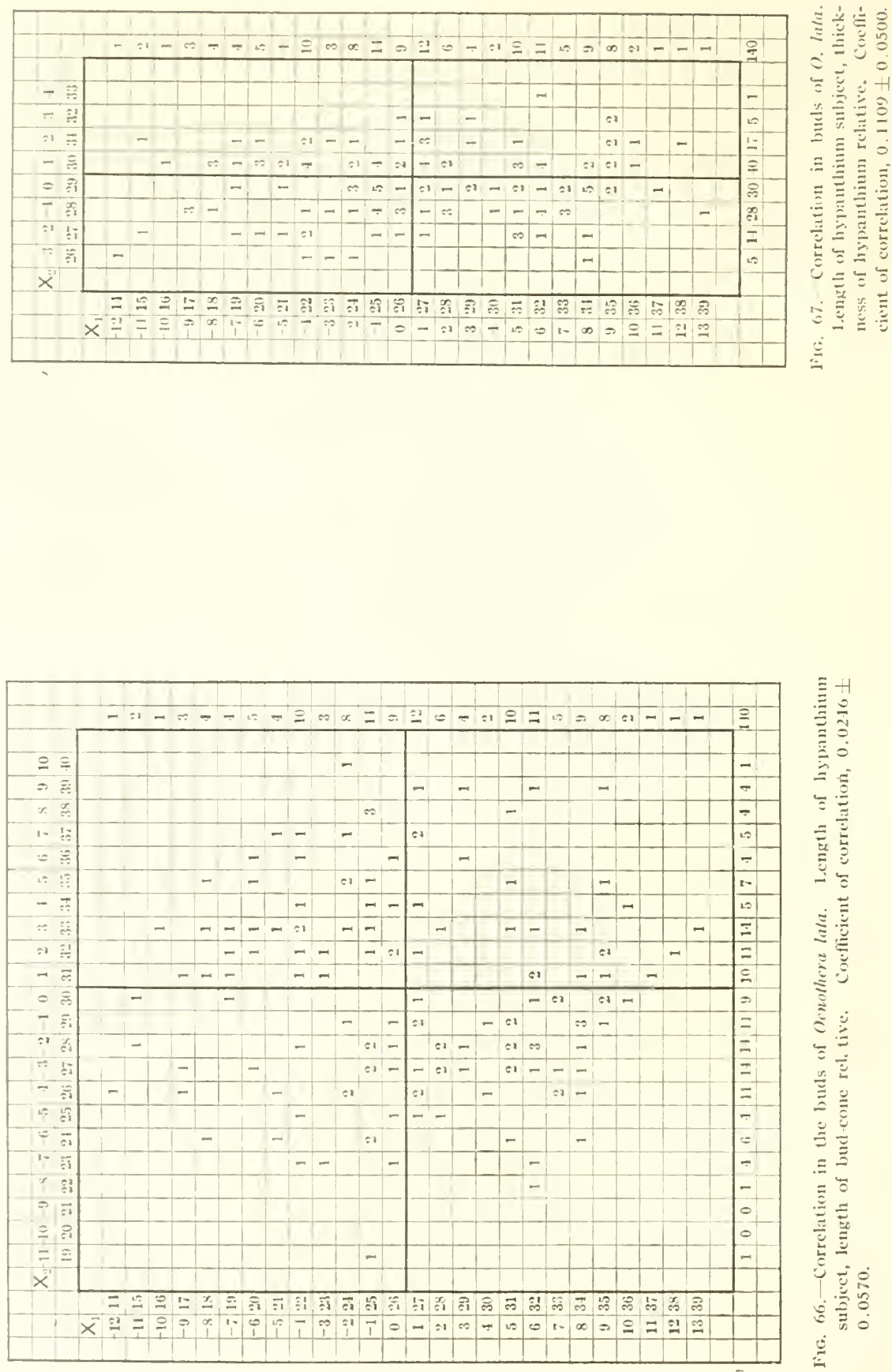


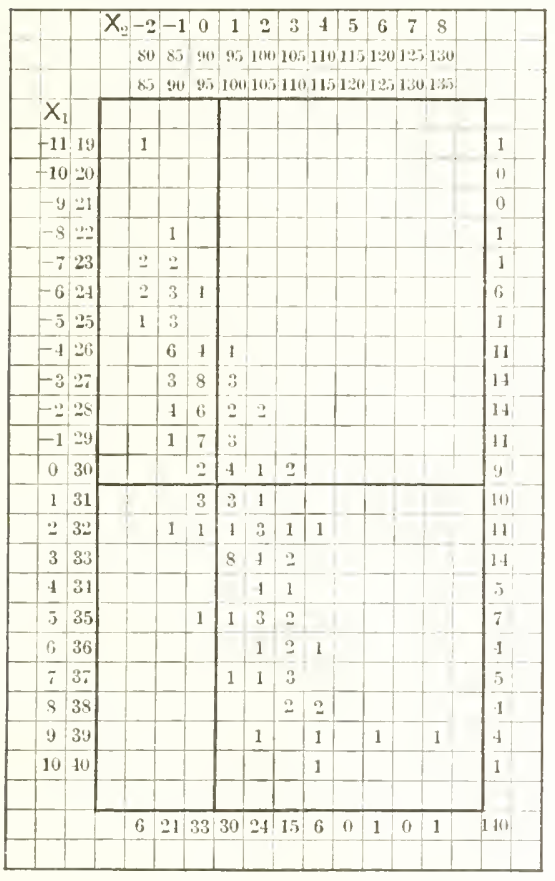

Fif. 68.-Correlation in the buds of () nothera lata. Length of bud cone subject, thickness of bud-cone relative. Coefficient of correlation, $0.8306+0.0171$

\begin{tabular}{|c|c|c|c|c|c|c|c|c|c|c|c|c|c|}
\hline & & \begin{tabular}{l|l}
$X_{2}-2$ \\
\end{tabular} & -1 & 0 & 1 & 2 & 3 & 1 & 5 & 6 & 7 & 8 & \\
\hline & & 80 & 83 & 90 & 95 & 100 & 105 & 110 & 115 & (13) & 125 & 130 & \\
\hline & & Si & 90 & 95 & $104)$ & Ju5 & 110 & 115 & 120 & 1251 & 130 & 135 & \\
\hline$x_{1}$ & & & & & & & & & & & & & \\
\hline-1 & 31 & 1 & & 1 & & & & & & & & & 2 \\
\hline-3 & 35 & & 2 & 3 & 1 & & & & & & & & 6 \\
\hline-2 & 36 & 4 & 8 & 7 & 4 & 1 & & & & & & & 24 \\
\hline-1 & 37 & & 5 & 8 & 3 & 6 & & & & & & & 22 \\
\hline 0 & 35 & & 4 & 5 & 1 & 3 & 1 & & & & & & 22 \\
\hline 1 & 39 & & 3 & 4 & 11) & 1 & 8 & & & & & & 26 \\
\hline 2 & 10. & 1 & 2 & 3 & 6 & 1 & 2 & 3 & & & & & 21 \\
\hline 3 & 41 & & & 2 & & 2 & 3 & 3 & & & & & 10. \\
\hline 4 & 42 & & & & 2 & 2 & & & & 1 & & & 5 \\
\hline 5 & 43 & & & - & & & & & & & & 1 & 1 \\
\hline 6 & 41 & & & 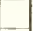 & & & 1 & & & & & & 1 \\
\hline & & & & & & & $\longrightarrow$ & & & & & & \\
\hline & & 6 & 24 & 23 & 30 & 24 & 15 & 6 & 0 & 1 & 0 & 1 & 140 \\
\hline & & & & & & & & & & & & & \\
\hline
\end{tabular}

Fig. 70.-Correlation in the buds of Oenothere lata. Thickness of ovary subject, thickness of bud-cone relative. Cofficient of correlation, $0.5839 \pm 0.0376$

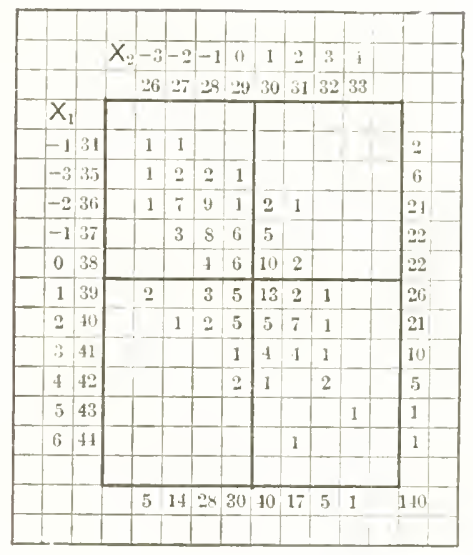

I'IG. 69,-Correlation in the louds of $O_{t \cdot n-}$ othera lata. Thickness of otary subject, thickness of hypanthium relative. Cofficient of correlation, $06+00$ $\pm 0.0336$

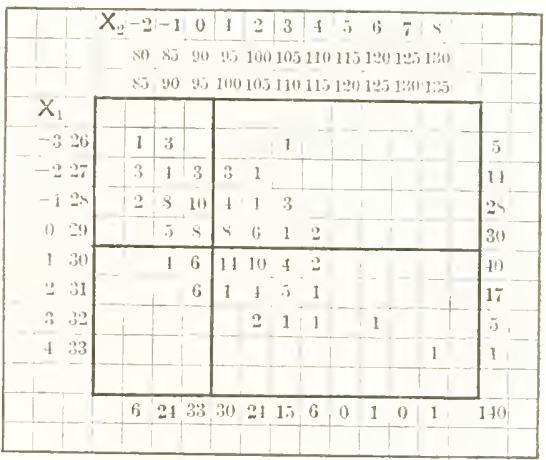

IFIG. 71.-Correlation in the buds of Oenothera lata. Thickness of hypanthium subject. thickness of bud-cone relative. Coefficient of correlation, $0.55+9+0.0394$. 
PIDIGREE-CULTURES OF OENOTHERA GRANDIFLORA, O. BIENNIS, AND O. CRUCIATA.

In order to test the mutative capacity of other evening-primroses, seeds were obtained from correspondents in various parts of the world and as many as to sowings were made in one year from O. biennis. In only one strain, however, did anything come to light which would be of interest in connection with the chief purpose of these investigations.

Parental individuals were selected and verified by Dr. N. L. Britton in 1903, and from the seeds furnished by them the plants were grown which furnished material for the descriptive diagnosis published in a previous paper (MacDougal, Vail, Shull \& Small, 1905). This is not the species growing wild in Europe and cited by De Vries in his "Mutationstheorie."

Inflorescences of 4 separate individuals were inclosed in transparent paper bags in such manner as to secure pure fertilization and the seeds preserved in separate packages. Sowings were made in pans of sterilized soil, in accordance with the usual custom, early in January, 1905.

A number of seedlings were seen in which the first foliage-leaf and all succeeding leaves were very much narrower than the parental type. Sixteen individuals of this kind were found and preserved, appearing in the progeny of all of the 4 parents represented. An exact colint of the number was kept only in the case of one parent, No. S.I7, in which + of these aberrants were included in a progeny of 669 individuals and formed very nearly 0.6 per cent of the entire number.

The aberrants retained their property of forming narrow leares, which were slightly paler in color than the parental type, and appeared to taper gradually at the base into long petioles. One aberrant of 8.17 gave off a lateral branch at the base of the stem whicl developed broader leaves resembling those of the parent. With the completion of development, the form of the capsules and the entire habit of this branch were in exact duplication of $O$. biennis.

On July 2 one of the aberrants opened a flower which also showed some departures from the normal, being cliaracterized by the extremely long stamens and by the elongated capsule, which was of equal diameter throughout and did not taper to a point or toward the tip as in its parental form. The first 4 flowers which were bronght to maturity on a lateral branch were inclosed in a bag and self-pollinated. The seeds formed were allowed to mature and these were sown as soon as practicable in order to determine the constancy of the new form.

The adult plant lias a main stem varying from 80 to $150 \mathrm{~cm}$. in height, and branches freely from the base upward. The lower branches are long, slender and assurgent, while the upper ones are much shorter. Numerous secondary 
branches arise during the latter part of the season. The stens are nearly terete below, but are slightly channeled above.

The stem-leaves are Io to $16 \mathrm{~cm}$. long, and not more than I cm. in width at the middle, obscurely pubescent on both surfaces, thickish, yellowish green, obscurely and irregularly denticulate, with a heavy, broad nidvein. The leaves are linear, and taper to the long acuminate tip and to the margined petiole.

The bracts are narrowly linear and $3 \mathrm{~cm}$. long. The conic portion of the bud is about $12 \mathrm{~mm}$. long and half that in diameter, pale yellow, and barely tapering in the apical portion, being finely pubescent. The free erect tips are irregularly acuminate and 2 to $4 \mathrm{~mm}$. long.

The hypanthium is 25 to $35 \mathrm{~mm}$. long and exceeds the calyx-lobes by half.

The filaments are 7 to $9 \mathrm{~mm}$. long, stout, and the anthers $4 \mathrm{~mm}$., slender. The pistil is slightly shorter or longer than the stamens, measuring 4 to 6 mm., and this species is therefore self-pollinated like the parental form. The stigmatic lobes are + to $5 \mathrm{~mm}$. long and spreading.

The capsules are 25 to $35 \mathrm{~mm}$. long, 4 to $5 \mathrm{~mm}$. in diameter, generally curved, sparingly pubescent, bright green and shining, scarcely tapering to the apex, and, in general, much thinner than the parental type. The ovary is about half or less than half the length of the mature capsule.

The sepals are $3 \mathrm{~mm}$. long, the petals firm, i 5 to $6 \mathrm{~mm}$. long and $\mathrm{I}_{5} \mathrm{~mm}$. wicle, being crenately emarginate (I905 c, p. I 7).

A small package of the lot of seeds from which the mutant was obtained originally were sent to Miss Elizabeth Billings, who sowed them in her greenhouse at W'oodstock, Vermont, in March, I905, and later transferred them to her experimental garden. The 499 plants thus obtained were kept under observation by Miss Billings and Professor F. S. I.ee, of Columbia University, with the result that aberrant individuals were found which were identical with those obtained during the previous September in the New Iork Botanical Garden.

The development of the newly arisen form has been followed from September, I 904, until the present time. The first individual discovered came into bloom on July 2, I 905, having been cultivated under glass during the preceding winter. Seeds were matured 5 or 6 weeks later, and sowings hare been made from them, with the result that the aberrant type was found to produce a progeny which contained not more than i 2 per cent of the atypic form of individuals, the remainder being of the parental type and unchanged. Hybridizations between the aberrant form and the parental form gave the same result, while the aberrant type when crossed with lamarkiana and with rubrinervis gave a progeny resembling in general constituency those produced by typical biennis. 
A similar aberrant of $O$. cruciata has been fotnd in many of the cultures of that species. Nuch attention has been devoted to these forms, both as to habits of growth and anatony. The only parallel occurrences are those which are to be found in other genera in which atypical individuals affected by the enzynatic discases may give a progeny in which the normal form of individuals predominates. The vigorous growth of the atypic individuals and the comparative regularity with which it appears are well worthy of remark. If these forms were found growing in the open, they miglnt casily be taken as belonging to a species apart from $O$. biennis unless their progeny was tested in pure cultures.

The pedigreed cultures of 0 . grandiflora made in 1906 from purely fertilized seeds of the previous year included about 1500 plants. More than one season of such cultures is necessary to secure definite results that may be depended upon. The observations have been carried so far at the New York Botanical Garden and the Desert Laboratory, however, as to warrant the assertion that this species presents a complex progeny analogous to that of lamarckiana, in which two well-clefined mutants are readily recognizable by reason of their striking differences from the parental form.

ORIGIN OF IIIEED FORMS BY HYBRIDIZATION.

That the cross-fertilization of two forms may result in the production of a unitypic or polytypic progeny in which the parental qualities appear in a mosaic is well known. Components of a native flora have been suspected to be of hybrid origin in a few instances, and by succeeding experimental tests liave been synthetized from the parents. The practice prevailing among taxonomists of ascribing a hybrid origin to a newly discovered form, which, in outward anatonical characters, is between two known species, is extremely pernicious and is not justified by facts obtained in cultural work. The best grounds for such a conclusion are to be found when two species alone occur in a region, and the appearance of a third is attributed to hybridization; but even here the supposition that a mutation may have ensued is allowable.

The hybrid O. lamarckiana $\times O$. cruciata (form with long hypanthium and slencler bucl), which was (lescribed in the previous publication by the authors, proves to be a fixed form, and as it sets seeds freely and is self-fertilizing, it is in every respect an independent species. Several hundreds of seedlings were grown from purcly fertilized eapstiles ripened in 1904 , with the result that all were seen to conform to the parental hybrid type in every particular. The two parental forms flo not meet in their native habitats, and hence this form could not have arisen in a state of nature.

T'lle reciprocal of this cross, that is, $O$. cruciata $\times O$. lamarckiana, consists of three forms, one of which is indistinguishable from the O. biennis cruciata which has been received from various fiuropean gardens. 


\section{BLD-SPORTS-IEGETATIVE SALTATIONS.}

One of the most interesting and least understood phases of heredity is that in which the tract of embryonic tissue constituting a bud may derelop and put into external realization a set of characters wholly different from those of the remainder of the individual. A large number of such instances have been seen by gardeners, horticulturists, and farmers, although exact observations on the hereditary qualities of such mutant branches are almost wholly wanting. In some cases the departure from the type does not affect the entire brancl, and it nuy not be made manifest until an advanced stage of its development, causing some of the leaves or perhaps some of the flowers to show atypic characters. When such partial regetative saltation ensues it generally results in converting a lateral seetion of the branch or inflorescence into the new form, and las been termed "sectorial variation" by De Vries. To designate it beyond danger of misapprehension, however, it should be known as sectorial bud-1nutation.

The cultures earried on in the experimental garden during 1905 were characterized by two remarkable bud-sports.

The hybrid $O$. lamarckiana $\times(O$. lamarckiana $\because O$. cruciata $)$ comprised nearly a score of recognizable forms in the seedling stage. About two of each type were transplanted to the experimental garden in May, 1905. Two of the types included were apparently different from each other only in the character that one of them bore flowers with broad petals resembling those of lamarckiana, while the other was furnished with cruciate flowers, but with the petals broader than the typical cruciata and quite as long as those of lamarckzana. It was evident that the two forms constituted an illustration of Mendelian combinations, alike in all particulars except as to the characters 11nited in the form and size of the petals.

Une of the individuals with the broadly cruciate flowers bore a branch near the base of the stem, on which were formed only flowers of the broadly-petaled lamarckiana type. Some of these were purely fertilized and seeds preserved for testing. These were duly sown in December, 1905, under glass, and representative individuals brought to bloom in the open air in July, 1906.

When they came into bloom in July, 1906, it was found that the branchsport came entirely true to the type which it represented. With this it is interesting to note that the purely fertilized seeds of the main stem bearing cruciate flowers gave a progeny which contained some individuals bearing flowers with broad petals, while the other strain, which bore only broad petals, came entirely true to its type withont deviation. No exact numerical count was made, but it seemed evident that the cruciate petal is dominant over the cordate, and that the plants described above exemplify the development of a sport on a plant of the first generation in which the recessive character appeared and when extracted cane true to the recessive character. 
De Iries (1900, p. S6) described a case of vegetative mutation in a hybrid between Veronica longifolia, which lias a blue flower, and $V$. alba with a white flower. The hybrid has a blue flower, but several eases were noted in which the entire buds or portions of inflorescences produced white flowers. These white sports, when self-fertilized, produced white flowers only, in the preliminary tests cited.

Similar regetative splitting is known in Datura hybrids, being seen by Nandin in 3 individuals only, while sports of this character of Brassica, Raphanus, Abies, Anagallis, Helianthemum, Zca, and Cytisus are well known. Nearly all other sports of hybricls are clearly of an atavistic nature, being more or less direct reversions, sometimes rehearsing the juvenile characters of one of the parents of the hybrids.

A second instance was offered by a form known as $O$. ammophila. This material was grown from seeds obtained from Professor IV. O. Focke, which had been collected on the coast near Bremen, Germany.

A large number of seeds were sown in sterilized soil in the propagating liouse on February 10, 1905. A month later the seedlings obtained were examined and a dozen representing the widest visible range of variation were transferred to pots, while the remainder of the culture was discarded. With successive repottings the number of individuals was reduced to 7 , which were transplanted to the experimental garden in the latter part of May, at which time no differences of moment were noticed. During the summer 3 of the specimens sent up shoots, while the other 4 formed dense rosettes with a few short lateral branches.

Abont the middle of August the more advanced individuals came into bloom. No careful examination of them had been made up to this time, but it was now seen that one of them lad formed a lateral branch at the base of the main stem, which, by the spread of its branches, the shape and expansion of its leaves, and its general vigorous grow th had become the larger member of the shoot. 'This branch, in the form and beliavior of all of its organs, including flowers and fruits, was an exact reproduction of the $O$. bicnnis which has formed the basis of cultures under that nane in the New Tork Botanical Garden. Branches of the sport and of typical biennis were submitted to several botanists, with the result that they were found to be indistinguishable by anatomical characters.

The main stem, which had branched in the usual manner, had been crowded from its natural upright position and had assumed a half-recumbent position, liaving the appearance of a lateral branch.

The suggestion lies near at hand, that $O$. ammophila is a hybrid derivative of $O$. biennis, and that the vegetative mutation is simply one of reversion, after the manner of examples cited above. No positive evidence upon the origin of ammophila is at hand, however. 
Purely fertilized seeds of the mutant branch and of the main stem were obtained, and these were sown late in September, 1905. Those of the main stem came true to the type of the main sten, that is, to $O$. ammophila. All of the progenyobtained from the purelyguarded seeds of the sport conformed strictly to the bicnmis type (plate 9).

\section{THE INDUC'TION OF MUTATIONS.}

One of the most important problems confronting the investigation in this subject is that of the localization of the mutations in the life-history of the plant. If we could fix upon the exact stage in which the direct changes occurred, we then would be in a position to examine the protoplasts concerned with a view to ascertaining what changes ensue in the chromosomes in connection with saltations in inheritance. Furthermore, opportunity would also be offered for attempts to determine the factors which operate as stimuli, or loosing agents in setting the mutations free.

A theoretical consideration of the subject seemed to indicate that the changes constituting the mutations which give rise to atypic seedlings took place in a stage previous to the reduction divisions in the embryo-sac or in the pollen mother-cell. It was planned, therefore, to subject these structures to the action of chemical agents at a time before fertilization had occurred. The attempt was made to secure two forms of stimulation by using some solutions of high osmotic valne, and other mineral compounds which are stimulative in low concentrations. A desideratum in such experimentation was to use plants in which a large number of ovules were to be found in one ovarial cavity. The solutions were injected into the ovaries by means of a plysician's hypodermic syringe. Operations of this character were carried out with Begonia rotundifolia and with a species of Clcome, but with negative results, and injections were also made into the central placenta of a number of flowers of Abutilon abutilon, but in all cases at a very late stage, and so far no results have been obtained with this plant. It is being used in a new series of experiments, however, which, with improved technique, may be expected to furnish some interesting material.

Attention was next turned to several species of Oenothera which were being cultivated in pure pedigreed strains in the experimental garden. Solutions of copper sulphate of I to 400,000 were injected into oraries of lamarckiana immediately previous to pollination and the pistils were purely pollinated. The capsules formed from ovaries treated in this way were variously distorted as a result of the wounding, but a large crop of perfect seeds was matured, which were sowed in September, 1905. A careful census of the seedlings late in November made it appear that in the small number of mutants present the usual mutants of this species occurred in normal proportions. 
A number of radium pencils were taken from a series useel by I)r. Gager in his investigations, ant were fastened in an inflorescence in such manner that a deleterious influence must have been exerted on some ovules, while in other ca es the effect must have been stimulative if the reactions of seedlings of otler plants may be taken to offer a fair analogy. The crop of seecls matured in the treated ovaries was sown in September, 1905, and late in November a census showed that only 20 normal specimens of lamarkiana were present and that 2 mutants were also inchelecl. The rate of mortality was thus seen to be twice as great in the type as in the mutants in this single test.

Sinilar tests were made with O. biennis. Solutions of nagnesimm sulphate in distilled water were used withont any noticeable departure in the composition or behavior of the grogeny arising from the seeds. P'oisonous solutions containing I part of zinc sulphate in 500 of distilled water were also used. The seeds produced in the ovaries which had received this treatment contained atypic forms of the kind seen in ordinary cultures in apparently the customary proportion of about one in 200. In addition howerer, a single rosette was found which differed widlely from any known type, and of this form, which was recognizably different from the parental type in many qualities, some of the differences were plainly apparent even in the earliest leaves of the seedlings. These differences have becone accentuated in the adult plant.

The parental form has been under observation for five years in cultures and in a wild condition. An aberrant form, which appears to be eversporting, has been previously figured, and while this form appeared in the injected or treated seeds in a normal proportion, vet the newesi aberrant has not been seen elsewhere. The probability must be taken into account that it may be a mutant of rare occurrence, the eycle of which came within the experiments; but in either case it is plainly an mutant, and it only remains to be seen whether or not it was induced by the action of the zinc solution. The presumption seenus to favor such a conclusion. Seeds of this form were harvested in Angust, 1906, and sown inmediately, with the result that the characters of the new form were fonnd to be fully transmissible, the first generation of the progeny being duplicates of the parent within the linits of fluctuating rariability. The entire plant is characterized by a much decper green color than the parental form and the leares are slightly curfed and twisted, owing to inecpualities of growth, and it reaches maturity quite early in the season.

In addition to the erop of guarded seeds harvested from some of the branches, the arailable remainder were collected and sown in the greenhouse of the bes.rt Iaboratory, with the result that this second generation of the derivative was found to conform exactly in every individual to the derivative type. lither the nntant does not intercross with the parent, alllough the branches were in contact, or if a cross has occurred the derivative qualities are dominant. 'llis matter may be determined by the tine this paper finds its way through 


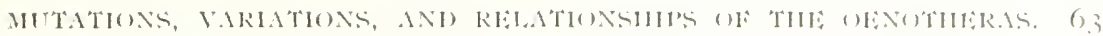

the press. Among the large progeny grown from guarded seeds was only one which showed any natkerl variation from the blunt romeded teares of the rosette of the derivative, but this variation did not extend to the foliar organs developet later.

The radium pencils which were later used on (). lemarkiuna were affixed to an infloreseence in sted a manner that the radium coatings were 1.5 to $2.5 \mathrm{~mm}$. from developing flower-buds. 'lthe corollas of many were so retarded that they failed to open and fell off prematurely. At greater distances develop ment of the ovary proceeded but slowly and normal size was not reached. Perfect seeds were formed in many of them, however, and these when sown gave the normal frequency of the aberrant mentioned above, and which is not to be confused with the one induced by the stimulative action of zine sulphate.

Some decisive results were also obtained from Kirmamuir odorata, a member of a separate genus of the evening-primrose family from Patagonid. 1)uring the first season (1905) injections of the ovaries were made with sereral sub, stances, with the result that an atypic form identical in all cases was found in seeds from ovules that had been treated in various wars. 'Two sucl mutants were secured from seeds of an ovary that had been treated with a 10 per cent sugar solution, 10 from one that had been injected witl a solution of calcium nitrate 1 part to 1000 of clistilled water, and one was also found in the progeny from seeds taken from a capsule which had been exposed to the action of a radium pencil.

In all of these injections ordinary jointed metal syringes were used, and the water was from a single distillation in a copper still, so that no special reliance may be placed upon the purity of the solution in jected into the ovary.

Seeds from capsules which had been treated were harvested in June, 190, 5 . and were sown early in July. The atypic derivatives could be recognized as soon as the cotyledons were fully expanded, and no skill was needed for the ir detection. 'The parental form bore leaves villous hairy, or with ciliate mar gins, while the mutant was entirely and absolutely glabrous. The leaves of the parent generally have an unbalanced linear growth of the margins by which the blades become fluted. The excess of growth in the mutant lies along the mitrib and the margins becone revolute. The leaves of the mutant show much less expansion than those of the parent, the lower ones being narrowly linear, 5 to $6 \mathrm{~cm}$. long and 3 to $\mathrm{t}$ mm. wide, while the upper ones are lanceolate linear, 3 to $f$ cnu. long or even longer, the nuntant being nuncli the narrower. The parental type is of a marked bieminal habit and near the close of the season the internodes formed are extrenely slort, which results in a dense rosette. 'The mutant does not make a rosette, ly reason of the fact that its stem does not alter its rate of congation, but proceeds at a uniformly rapid rate, thus presenting a leaf-stem which appears to be perennial in the climate in which the experiments were performed. So rapilly did develop- 
ment proceed that one of the atypic individuals opened a flower-bud on November 27, 1905, and seeds were liarvested before the beginning of the year. Other lots of seeds were obtained throughout the year and several sowings were made, with the result that the atypic form was found to transmit itsconstellation of characters to its offspring. Among the fully atypic individuals, of which a few hundred have been grown, one was found with wide leaves like the parental form, another with eiliate leaves, and another with undulate leaves. This activation of parental characters is one fully illustrated by lamarckiana and its derivatives and shows that the treatment has simply thrown certain parental characters into a state of latency and awakened others with which the parental characters are mutually exclusive as to external manifestation. These individuals did not afford a transition or intergrading series between the derivative and the parental form, however (plate ro).

In the summer of 1906 a second series of injections was made, with the result that capsules treated with zinc sulphate, I part to 2000 parts of distilled water, yiclded seeds which produced progeny inclusive of the atypic form. deseribed above, and also some other combinations which it has not been possible to follow in successive generations. The group, however, bears a general resemblance in relationship to that of the lamarckiana mutants.

An injection witl ealeium nitrate, I part to 1000 of distilled water, was without effect and the progeny were all of the parental type. It was remarkable, lowever, that a treatment with this substance in the previous season had secured some atypic forms, probably due to some opportune condition in the experiment not yet understood. Furthermore, the plants of the progeny of the first treatment which were apparently normal yielded seeds which gave a few atypic forms, indicating that the effect of the first treatment had been more or less permanent. Confirmation of this important matter has not yet been obtained, however. Then, again, an injection of ovaries in 1906 with the distilled water subject to impurity from the still and from the syringe, as mentioned above, also resulted in a progeny in which some atypic forms were found to occur. Sofar, then, as experience with this plant is afforded it is to be seen that a variety of agents act in indueing discontinuous variation in the progeny and that in one instance the variability was carried to the third gencration, as far as that part of the test las been extended. The atypic forms transmit their qualities perfectly from generation to generation, and the third generation now in hand are like the first from which they came originally. 


\section{IDENTITY OF EVENING-PRIMROSES.}

Prepared by ANNA MURRay TaIL.

In view of the extent to which the erening-primroses are being used to obtain experimental evidence upon questions of heredity at the present time, it has been deemed important to make a systematic study of the group. To this end seeds have been obtained from correspondents in various parts of America and fiom European botanical gardens in which these plants appear to be extensively cultivated.

In the few years in which the cultures have been under way it has become plainly apparent that a much larger number of species are native to America than has been supposed hitherto. The series of pedigree-cultures made from them, using carefully guarded seeds, shows that botanists have customarily grouped many elementary species under the name of $O$. biennis. Furthermore, as has been noted on page 8 , none of these appear to coincide with the form cultivated in Europe under this name.

Several of these elementary species occur on Long Island, a number of them collected by Mr. E. P. Bicknell deserving mention, and requiring special study to determine their relationship to the common $O$. biennis.

Another group of closely related but apparently distinct elementary species came from the west shore of Lake Champlain. There, in waste ground at the roadsides about Plattsburg, fairly typical O. biennis is to be found. A smallflowered and very characteristic plant abounds on inland sand-dunes, in sandy clearings along the Ausable River, and on the railroad embankments near Bluff Point. In the Ausable River woods it grows associated with $O$. cruciata, and a supposed hybrid between the two was observed. Occasionally a larger-flowered form on the edge of woods was observed and still another on the gravelly shores of the lake. These types, with the exception of the hybrid of which no mature seed was secured, were grown in the New York Botanical Garden, where they reproduced in every particular the characters that distinguished them in the field. They will require more extended study for the determination of their specific relationships.

The more important facts concerning the anatomy and distribution of a few forms have been obtained and descriptions of $O$. grandiflor $a$, $O$. simsiana, $O$. oakesiana, $O$. parviflora, and $O$. muricata are here presented. It is proposed to reserve discussion of the large number of other distinct forms until their life-history and hereditary qualities shall have been more definitely ascertained. 
The use here of the name Oenothera for species belonging to the genus Onagra (Tournefort, Adanson, Spach) is according to the decision of Dr. J. $\mathrm{N}$. Rose in a recent paper (1905), where he points out, and with good reason, that Uenothera biennis should be considered as the type of the genus. The descriptions in each case have been made from living plants.

\section{OENOTHERA GRANDIFI.ORA AITON}

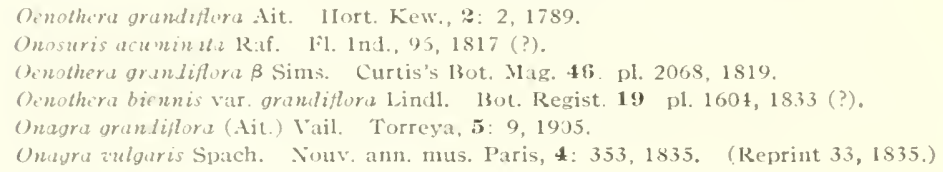

Seedling about 2 months old.-Rosette loose, spreading, 7 to $12 \mathrm{~cm}$. in diameter; onter leaves 4 io - cml. long, 2 to $3 \mathrm{~cm}$, wide; blades oblong, or ollong-spatulate, nearly glabrous, irregularly blotched with dull red, broader above the middle, rounding or acutish and slatlowly undulate toothed at the apex, tapering at the more deeply toothed base into the margined petiole; the inner blades oblong, acutish, and soon becuming more deeply toothed at the base (plate 11, A).

Sevdling about 5 months old.-Rosette rather loose, spreading flat on the ground, about $30 \mathrm{~cm}$, in diameter; onter leaves 12 to $15 \mathrm{~cm}$. long, 3 to $+\mathrm{cm}$. wide; blades oblong-spatulate, broadest above the middle, acutish at the apex, tapering at the irregularly pinnatifidtoothed base into a long, broal petiole, obscurely puberulent near the outer margin above and beneath on the white midvein and veins, bright dark blue-green, irregularly blotched througlout with red, which color also appears sometimes on the widle white midvein (plate $1 \mathrm{I}, \mathrm{B})$.

1dult plant.-Plant $\mathrm{r} .5$ to $3 \mathrm{~m}$. in lieight, branching from the base upward, the terminal fortion of the main sten bearing a cluster of short branches with a profusion of flowers. Sienis stout, often reacling a diancter of $6 \mathrm{~cm}$. at base, nearly terete below, slightly angled and channcled above, or sulcate, the epidermal tissues becoming detached on the lower lart of the main stem, which is lard and woody, clothed in the upper portion with short, spreading, some what varyingly muricate pubescence; leaves 10 to $20 \mathrm{~cm}$. long; blades ovatelinceolate, glabrate, with appressed scattered hairs on the veins, denticulate, being more decply and irregularly toothed in the basal portion, tapering to a short margined petiole, hright green and shining above, paler beneath; terminal rosette-like cluster of the inflorescence symmetrical; flowers very alundant and fragrant; Dracts lanceolate, 3 to $5 \mathrm{~cm}$. long, acuminate, abruptly tapering into a short petiole, or sessile; conic portion of bud 3 to $4 \mathrm{~cm}$. long, 6. $10-$ mms. in diameter at base, very slender, tapering from base to apex, sparingly pubescent, thin, dotted with small red spots, the erect free tips very slender, setaceous, 8 to 10 mm. long: hypanthium 4.5 to $5.5 \mathrm{~cm}$. Long, very slender, much longer than the reflexed calyxlolies that ustrally coliere in airs at the tips: ovary $1 \mathrm{~cm}$. long, or less, slender, petals firm, $3.5(0)+$ tm. long, and about + cm. wide, more or less emarginate, wedge-shaped at base; filanents $2.5 \mathrm{~cm}$ long, very slender; antlers slender, $1 \mathrm{~cm}$. long; pistil much longer than stanens, and projecting from the flower and from the umopened louds late in the season; stigmatic lobes to t1 12 mml long; capsule 3 to $3.5 \mathrm{~cm}$. long, 8 11mm. in diameter in thickest prortion, green and shining, glabrous or with a few scattered hairs, four-angled and tapering from base (plate 12).

Hahama,-Earle's Ianding and Dixie Ianding near Tensaw, 'Tracy, No. Soos in the herbarium of the New York Botanical Garden. 
Texas.-Wright, without locality, in the Gray Herbarium of Harvard Lniversity (?).

Kentucky.-Neighborhood of Lexington, Short, withont date, in the herloaria of Columbia University and Academy of Natural Seiences, Philadelphia. The sheet in the Columbia University herbarium bears the note "Oenothera muricuta. Iispertine, 3 to 5 feet high." This is the sheet referred to (MacDougal, Vail, Shull \& Small, 1905, 1) 6) as belonging to (1. lamarckiuna, but which in the writer's opinion should belong here. The Pliladelphia specimen gives the exact locality "Neighborhood of Lex" ${ }^{\mathrm{n}}$ fl. Augt. \& after, i mile from town left of Coles road to Frankfort." It may be an escape from cultivation.

The rediscovery of the original type locality of this species is recorded in a previous paper (MacDougal, Vail, Shull \& Small, I905, pp. 7 and \&). The seeds from which the plants described above were raised were sent to the New Tork Botanical Garden from Tensaw, Alabama, by Mrs. J. F. Davis at the request of Professor Tracy, absolutely ripe capsules not having been found at the time of his risit late in August, 1904. In cultivation, O. grandiflora has the appearance described by Bartram in I793 and again by Professor Tracy in 1904. (MacDougal, Tail, Shull \& Small, i 905, pp. 7 and 8).

It is very fragrant and showy, and flowers abundantly. Most conspicuous and characteristic are the tapering pale-yellow buds with long, slender, setaceous tips to the calyx-lobes. They have none of the heary, swollen appearance of those of $O$. lamarckiana and of some of its derivatives. For 24 hours or so before the opening of the flower the closed stigma crowded into the a pex of the bud is distinctly seen through the thin epidermis of the closed calyxlobes. The calyx-lobes when expanded are split open in twos (but very rarely in fours), the petals only attaining their full size during expansion. This is also the case in Oenothera argillicola (Onagra argillicola McKenzie). (MacDougal, Vail, Shull \& Small, I905, p. I 2.)

A further comparison of supposed plates of $O$. grandiflora with living specimens of the species would indicate the following: The plate of "Ocnothera Iamarckiana" in Lemaire (Illustration horticole, 9, p. 318, I S62) appears to be that species, but the description of the 600 flowers, buds, and capsules on one single plant would appear to refer to $O$. grandiflora, as $O$. lamarckiana does not (in cultivation) flower so abundantly. The plate in Edward's Botanical Register No. $160+$ of "Oenothcra biennis var. grandiflora" has much stouter bud-tips, bracts that are broader at the base, and much broader petals than the trpical $O$. grandiflora.

The plate Ocnothcra grandiflora Sims (Curtis's Bot. Mag., p1. 2068) is quite typical of the plant grown in the New York Botanical Garden as to the shape of the petals, but the bud-tips are much too heary and the bracts too broad and clasping at the base.

Large-flowered evening-primroses have appeared from time to time in the eastern seaboard States; but none that have been examined so far can be determinerl as being certainly indigenous there. In the Gray Herbarium the following specimens are noted. 
New Jcrsey.-Pine barrens, Miss Treat of Vineland, 1871, "wild." 'This has a flower that when expanded must have measured nearly $10 \mathrm{~cm}$, in diameter, the petals being $5 \mathrm{~cm}$. long and over, but the bud is stouter and heavier than (). grandiftora and lias more the character of that of O. lamarckiana. It might be interesting to know whet leer it still survives in the pine bartens.

Maine, Orono. M. L. Fernald, July 17, is 92 . A speeimen with very much the appearance of (enothera motrincris, laving the very characteristic hud of that derivative of $O$. lamarckiana. It is probably not indigenous. Iarge-flowered specimens labeled Oenothera biennis var. grandiflora and Oenothere grandiftora from California appear to be Ocnothera hookeri Torrey \& Gray.

\section{OENOTHERA SIMSIANA SERINGE.}

Oenothera corymbosa Sims. Curtis's Bot. Mag., 45 pl. 1974, 1818. Not Lamarck. Onagra spectabilis Spach. Nouv, ann. unus. Paris, 4: 352, 1835 . (Repr. 32, 1836.)

Oenothera simsiana Seringe, in DC. Prodr., 3: 47, 1828.

Siedling about 6 wecks old.-Leares glabrate; blades oblong, those of the later leaves oval, 20 to $35 \mathrm{~mm}$. long, so to $15 \mathrm{~mm}$. wide, obtuse at the apex, gradually tapering into the margined petiole, light yellow-green (fig. 72).

Sicalling atout 5 montls. oll.--Rosettes rather loose, to to 45 cri. in dianeter, spreading; outer leaves 15 to $20 \mathrm{~cm}$. long, t to $6 \mathrm{~cm}$. wide; blades oblong to obovate, broadest somewhat above the middle, tapering to the obtuse apex or in the younger leaves to an acutish apex, gradually tapering into the broad petiole, light yellow-green, (o)scurely puberulent, with widely scattered lairs on both surfaces (under a lens), approximately repanddenticulate with ratlier distinct shallow teeth; petiole ris. 2.-Oenothera simsinu seedling about 6 weeks after germination, white, 8 mun. or more wide.

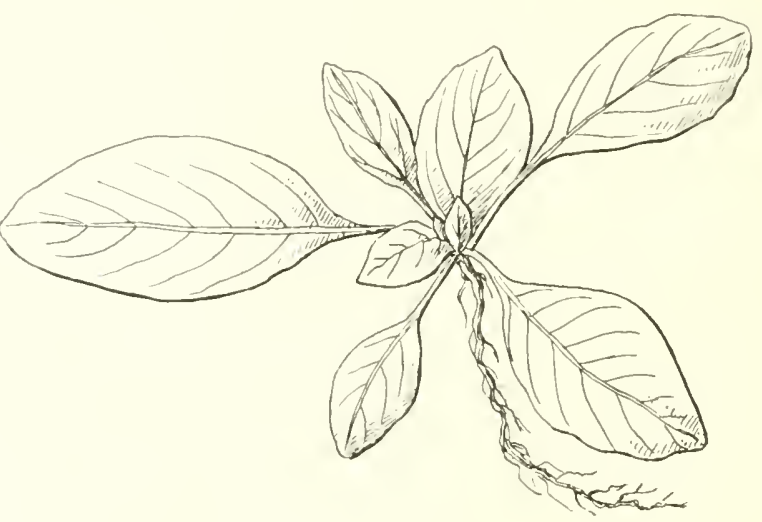

Wature rosette.-Leaves loosely spreading, finely but obscurely pubescent all over, the larger ores 20 to $28 \mathrm{~cm}$. long, 5 to 6 cul. or hore wide; blades oblong to oblong-obovate, slallowly repand-denticulate, tapering into a very wide white-1nargined petiole (plate 13 ).

.1dult plant.--Plant rather straggling in appearance, appressed-pubescent and hispidulous, especially in the upper portions. Alain stem about $2 \mathrm{~m}$. in height, greenish-white, beconing reddish, stout, terete, or slightly angled and sulcate above, irregularly branched at the base, the long, rather weak, virgate branches ascending; leaves minutely pubescent abore, somewhat less so beneath, 7 to $10 \mathrm{~cm}$. long, blacles olscurely repand-denticulate, oblong-lanceslate to lanceolate, acute or acuminate at the apex, abruply narrowed into a very short margined petiole or the uppertuost sessile, coriaceous, very brittle, bright yellowgreen, soon turning red, twisted, the upper ones more markcdly so; terminal rosette-like cluster of the inflorescence symmetrical, the floral bracts divaricate and somewhat reflexed; bracts lanceolate, acuminate, subsessile and subcordate; conic portions of the bud $2 \mathrm{~cm}$. long, 6 to $7 \mathrm{~mm}$. in dianeter at the base, canescently appresed-puljescent and lirsute, 
tapering in terminal portion only, the erect, free tips of the sepals, 3 to $+\mathrm{mim}$. long, nostly unequal; hypanthium 4 to $5 \mathrm{~cm}$. long, very slender, densely appressed-pulescent; ovary I 2 to I $3 \mathrm{~mm}$. long, slender, densely appressed-pubescent; sepals 3 to $+\mathrm{cm}$. long, shrorter tlian the tubular portion of the liypanthium; petals thin, briglit golden-yellow, fading saffronyellow, $+\mathrm{cm}$. long, + to $5 \mathrm{~cm}$. wide, deeply emarginate; filaments $25 \mathrm{~mm}$. long, very slender; anthers slender, 12 to $15 \mathrm{~mm}$. long; pistil as long or sliglitly longer than the stamens; lobes of the stigma 6 to $7 \mathrm{~mm}$. long, divaricate; capsule about $3 \mathrm{~cm}$. long, 6 to $7 \mathrm{~mm}$. in dianleter at the widest portion, 4 -angled, appressed-pubescent, rather abruptly contracted at the apex (plate 14).

Type locality of the plants described above, along International Railroad, City of Mexico. Collected by J. N. Rose and Jos. H. Painter, September 2o, 1903. No. 7219.

Seeds of a late-flowering plant were sent to the New Jork Botanical Garden, unnamed, by Dr. Rose late in r9o4, and the plants from which the above description was compiled were grown under glass for the first 6 months and then transferred to the experimental grounds. The flowers produced at the height of maturity are somewhat larger than those received with the seeds, but the late summer flowers exactly resembled those from the original locality. Remarkable for the form and color of the light green rosette and for the very characteristic assurgent or erect habit of the slender virgate stems and the acuminate, curved, and twisted leaves.

This species is referred to Oenothera simsiana, perhaps somewhat doubtfully. The plate (1974) in Botanical Magazine agrees with it, except for the corymbose inflorescence, which may occur readily enough in the plant in its native labitat, as many related species vary in that regard. The mature and normal capsules do not show the strongly reflected, white valve-tips that are seen in the illustration, but the plant as cultivated in the New York Botanical Garden was subject to the sting of an insect that caused a malformation of the ovary or young capsule, which then had very much the appearance of the capsules in Sims's plate, though when malformed they never quite reached the state of maturity depicted there. This is what may have occurred at Longleats in $\mathrm{S} \mathrm{r} 6$.

O. simsiana, with the synonymy as given above, is listed in Hemsley (Biol. Centr. Am., 1: 454) without any indication of definite locality or collection.

An unnamed Oenothcra collected at the city of Durango and ricinity, by Dr. Edward Palmer (No. 293, I 896, in the herbarium of the New York Botanical Garden) can be referred here with a fair degree of certainty.

O. simsiana is closely related to Oenothera hookeri Torrey \& Gray, with which it has doubtless been confounded in herbaria. The growing plants are, however, very dissimilar from that species in general aspect and liabit from. the rosette stage to maturity, and the flower appears to retain its yellow color very mucli longer than does $O$. hookeri. 


\section{OENOTHERA OAKESIANA (ROBB1NS) S. WATSON.}

Oenothera bienns var. oakesiana Robbins. A. Gray, Man., ed. 5, 178, 1867.

Oenethera oakesiana S. Watson. Biblio. Ind. N. Am, bot., 383, 1878.

Unagra oakesiana Britton. Mem. Tor. bot. cl., 5: 233, 1894.

Scedling about 2 months old.--I,eaves obscurely puberulent, with few scattered hairs; blades oblong or oblong-obovate, 6 to 8 mm. wide, romnded or obtuse at the apex, tapering to a slender margined petiole (plate $15, \mathrm{~A}$ ).

Secdling about 5 months old.--Rosette crowded, symmetrical, 7 to $8 \mathrm{~cm}$. in diameter; onter leaves 3 to $+\mathrm{cm}$. long, s to ro mm. wide; blades oblong-ovate, broadest above the 1niddle, oltuse at the apex, tapering to the white, margined, entire petiole, dull or pale blue-green, rather fleshy, approxinately denticulate above, glabrous, except for a few obscure hairs on the margins.

Secdling 8 months old.-Rosette 9 to $10 \mathrm{~cm}$. in diameter, very symmetrical and crowded, raised above the ground with a few of the old leaves adhering to the rootstock; blades approxiniately and nore prominently denticulate.

Mature rosette.-I,eaves more or less strigose-pubescent all over, the central ones quite densely so, the larger ones from 15 to $20 \mathrm{~cm}$. long; blades narrowly lanceolate, approximatelyand shallowly toothed at the acute apex, more decply toothed at the slender, tapering base (plate $15, \mathrm{~B}$ ).

Adult plant.-Plant I to $1.5 \mathrm{~m}$. high, rather slender, clothed nearly throughout with a fine, close, strigose, appressed, and somew hat cinereous pubescence and few scattering longer spreading hairs, becoming almost glabrate and glancons with age. Stem light or whitish in color, angled and channeled above, branched to the micldle; leaves to to $15 \mathrm{~cm}$. long; hades shallowly and remotely toothed, often more deeply so at base, narrowly lanceolate, acute and tapering at each end, sessile or nearly so, gray-green and shining above, paler beneath, rather thick and somewhat brittle; terminal rosette-like clustcr of the inflorescence symmet rical, the floral bracts very small, divaricately spreading; bracts narrowly lanceolate, more decply and regularly toothed than the leaves, acuminate at the apex, tapering to the base, sessile, becoming 2.5 times as long as the mature capsule; conic portion of bud to to 1.3 11m. long, ratlser prominently t-angled, 4 to $5 \mathrm{~mm}$. in dianeter at the base, the free sepurate divaricate $1 \mathrm{i} p \mathrm{~s} 5 \mathrm{~mm}$. long, fincly but inconspicuonsly appressed jullescent; hypanthinum 2.5 mm1. to 2.7 m1m. long, slender, finely lut sparingly pubescent; calyx-lobes half as long as hypant hium; petals firm, 13 to $15 \mathrm{~mm}$. long, $\mathbf{2}$ to 1 t $\mathrm{mm}$. wide, deeply emarginate, not ofening widely; filaments $12 \mathrm{~nm}$. long; ant hers $7 \mathrm{~nm}$. long; pistil as long or slightly shorter than the exserted stanens, the lobes ereet, 4 to $5 \mathrm{~mm}$. long; capsules 3 to $3.5 \mathrm{~mm}$. or more long, ; to $9 \mathrm{~mm}$. in cliameter, angled and rounded, fincly appressed-pubescent, abriptly constricted near the apex. Remarkable for its large seeds (plates 16 and 17 ).

Massachusetts,-Cxbridge, J. W. Roblins, August, 18 ;8.

Rhode Islund.-Providence, E. P'. Bicknell, Aug11st, 1896; Septenther, 1899.

Now York.-New York Botanical Garden, D. T. Nacbougal, September, ryot; Cold Spring Harloor, Long Island, G. H. Shi1ll, September, 1904.

The above specimens are the only ones in the herbaria of the New York Botanical Carden and Columbia University that can with any degree of certainty be referred to O. oakesiana. The Robbins specimen is from the herbarium of the late Rev. Thomas Morong and attached to its sheet is the following note in the writing of its discoverer. 
OENOTHERA OAKESIANA MILI.

This plant was presented to Professor Gray many years ago as a well characterized and distinct speeies, which I still consider it. I discovered it in the medical colleges in New Haven, Connectieut, in 1 S27. In $1 S_{3}$ I sowed its seed with thuse of the ordinary variety. The differences are as follows:

(1) If raised from seeds sown in the spring it is annual, the common variety by its side being biennial.

(2) The leaves of the first year, when biennial, are much narrower.

(3) The pubescence throughout is soft-appressed, that of the other leing coarser and spreading.

(4) The points of the ealyx are always spreading, in the other appressed.

(5) The capsule is longer and more taper.

(6) The ripe seeds are larger.

I have found but two other localities, nanely, on sides of the railroad north of Norton, Massachusetts, and another, same situation near Apponong Depot, Rhode Island. Also, it is well naturalized in Uxbridge, Massachusetts, fron my seeds.

$$
\text { UxBRIDGE, } 5^{\text {th }} \text {. Sept., is } 7 \text { S. }
$$

J. IV. RoBbris.

The plants from the New York Botanical Garden were first noticed by J)r. Mac Dougal late in the summer of r go4. They grew not far from the embankment of the Harlem Division of the New Tork Central Railroad and were quite abundant, though not covering a rery widespread area. With them were associated a number of ().bicmis, the latter in that particular spot, however, being not as abundant as elsewhere in the garden. Rosettes were obtained of the (). oakesiuna and the plants raised from them the following summer were in every way similar to the wild plants, and formed the basis of these notes on the species. Plate 17 was photographed from a specimen growing wild in the New York Botanical Carden.

\section{OENOTHERA PARIIFIORA IINNETS}

Oenothera pariflora Linnzeus. Syst, ed. 10: 998, 1759.

Onagra pariflora Moench. Meth. Supp!., 287, 1802.

Seedling about 6 weeks old.-Rosette 2.5 to $3 \mathrm{~cm}$. in diameter, rather loose and irregular, blades of the leaves orate or orate-spatulate, slabrate, ciliate.

Rosctie about $3 \mathrm{~m}$ 'nths old.-I,eares fincly pubescent on both surfaces, less so above; blacles various, those of the earlier leaves narrowly oblong or oblong-spatulate, varying to oblong-obovate, 6 to ro cm. long, the larger ones 2.5 to $3 \mathrm{em}$. wide, approximately and shallowly denticulate, obtuse or nearly so at the apex, gradually narrowed to the base of the margined petiole, which is very early streaked with red or pink.

Mature rosette.-Leaves long and slender, spreading tlat on the ground; blades lanceolate, or oblong-lanceolate, aeutish, irregularly and strongly denticulate, more deeply toot hed at the long, tapering base, dark green and shiny, sparingly mottled wit thed, sparingly puherulent above, more so and paler beneath, 15 to $30 \mathrm{~cm}$. long, 3 to $5 \mathrm{~cm}$. wide; petiole white, $\mathrm{S} \mathrm{mm}$. wide, margined to base, distinctly pink or red ringed most of its length (p)lates is and 20).

Adult plant.-Central stem not always maturing the first season when forced. Lateral branches of annual rosette stout and angled, pubescent with spreading hairs; loaves resembling those of the rosette in color, texture, and pubescence; blades oblong to oblong- 
lanceolate, tapering to the slint, margined petiole, slallowly and approximately denticulate above, some of them crinkled close to the nidvein; terminal rosette-like cluster of the inflorescence symmetrical and spreading; bracts lancenlate, acute, sessile or nearly so, divaricate, crowded on short internodes; flowers munerous; bud club-shajed, the conic portion $8 \mathrm{~mm}$. long, 3 to + mm. in diameter, rarely angled, the free tips separate, quite slender, ereet, 2 mm. long or less, mostly tipjed with red: hypanthiun 3 to $3.5 \mathrm{~mm}$. long, slender, puberulent; ovary 8 to $9 \mathrm{~mm}$. long; calyx lubes one-thirel as long as the hypanthium; petals firm, $\mathrm{s}$ mm. long, 9 mum. wide, deeply cmarginate, cuneate; filaments 7 mm. long; anthers i to $5 \mathrm{~mm}$. long, pist il shorter than the slightly exserted stamens, the lohes divaricate, 3 to + mm. long, capsules abundant, $2.5 \mathrm{~cm}$. long, $6 \mathrm{~mm}$. in dianeter at the widest portion, bluntly t-angled, pubescent, briglit green, much thinner in apical portion. ('The apex of some of the valves are occasionally more or less (iistinctly bifid.) (Plate 10.)

Illustration.-Meerburg, Planterariores, pl. 34, 1789 .

Farly in 1906 a package of seeds distributed as Oenothera parviflora was received from the Botanic Garden of Madrid, Spain. The plants raised from these seeds differed essentially from any of the various so-called $O$. biennis of linropean origin in cultivation in the experimental gronnds of the New York Botanical Garden. The plants were very persistently biennial, and only one or two of those placed in the open threw ont lateral branches, the main branch only starting its growth too late in the auttmun to mature. Specimens of any Cenothera closely resembling it are not to be found in the lierbaritum of the garken or in that of Columbia University. As $O$. pariflora Linnæus was credited to "Canada to Virginia" by Pursh (F1. Am., Sept., 26 I, I 8 I 4), with the further note that it was rare, the development of the Madrid plants was followed and recorded with the hope that eventually the species night still be fotnd a component part of the North American flora.

Late in the fall of 1905 , Miss N. M. Stevens sent in some rosettes of what she consiclered as two distinct species of Oenothera collected in the neighborhood of Sonth Harpswell, Naine. The rosettes were placed in the experimental greenhouse for the winter and later Miss Stevens sent seeds of both species from the same locality. 'These latter germinated in the greenhouse and thougl somewhat similar in the carly rosette stage, one of them, the "prevailing species" of the locality from whence the seecls came, was identified with the plant determined as O. muricata Linneus and the other, the "rarer species" growing on sandy wastes, was identical with the species grown from the Madrid garden seeds under the name of $O$. parciflora, and it is from the plants raised from Miss Stevens's seeds that this description has been draw1 (plate 20).

The species shows distinct characteristics in color and habit. The flowers are but rarely exserted beyond the bracts, wlich are so crowded on short internodes that the ends of the branches have a closely-tufted appearance.

The I,innean description nnder Oenothera reads: "Parviflor. A. OF. fol. orate-lanceolatis planis, caule laevi subrelloso. Margo coronans fructum, non uti pracedentis quadrifidus, sed octofulus." 
The last character would appear to be an accidental one, that is, if the name belongs at all to the plant in question here, and it is extremely doubtful if that point can ever be definitely settled.

Some of the capsules of the Madrid plant showed a distinct bifid termination of the valves of the capsules, but in the Maine plant that character was less distinct or altogether lacking. The Spanish plants and those from Maine, growing side by side, were not distinguishable, but the Naine plants matured more rapidly.

\section{OENOTHERA MURICATA LINNAES.}

Oenotheru muricata Linnæus. Syst, ed, 12, 263, 1767.

Onagra muricala Moench. Metil., 675, 1794.

Scedling about 6 wecks old.-Rosette crowded and a little irregular, 2 to $3 \mathrm{~cm}$. in diameter, blades of the leaves oblong, glabrate, slightly ciliate on the margins.

Secdling about 3 months old.-Rosettes crowded, 7 to $8 \mathrm{~cm}$. in diameter; leaves 3 to $3.5 \mathrm{~cm}$. long, 7 to $8 \mathrm{~mm}$. wide, blades oblong-spatulate, broadest above the middle, obtuse at the apex, tapering into the margined petioles, blie-green, flesliy, glabrate or becoming appressedpubescent as the leaves increase in size, obscurely denticulate, the apex of the denticulations mostly reddish.

Mature roscttes about 5 months old.-Rosetts 15 to $17 \mathrm{~cm}$. in diameter, rootstock thick, raised 2 to $3 \mathrm{~cm}$. above the ground, bearing a few old leares under the later green ones; learcs crowded, the outer 9 to $1.4 \mathrm{~cm}$. 1ong, 1.5 to $2 \mathrm{~cm}$. wide; blades approximately dent iculate, irregularly and more deeply so towards the base above the broad, white-marginer petiole, appressedpubescent or hirsute, without any trace of red in the leares, exrept at the apex of the denticulations.

Adult plant.-Plant I.5m. high, pubescent with short appressed as well as longer spreading hairs throughout. Stems erect, stout, I to $1.5 \mathrm{~m}$. high or more, single or generally branched above, angled, turning red and the outer bark splitting into shreds at maturity; stem-leaves rather crowded, Io to $15 \mathrm{~cm}$. long, 1.5 to $2 \mathrm{~cm}$. wide; blades narrowly lanceolate or linear-oblong, acute, approxinately denticulate, inore deeply so at the base, appressedpubescent with short strigose hairs more or less on each surface, Fig. 73. - Seedling of Oenolight green, paler beneath; terminal rosette-like cluster of the inflorescence barely symmetrical; midvein broad, whitisl1; inflo-

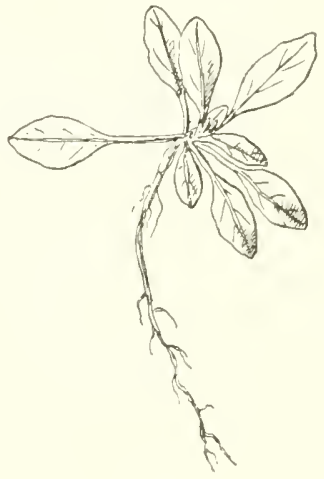
months old. rescence crowded; bracts lanceolate, acute at the apex, tapering to the sessile base, finally two or more times as long as the mature capsule; conic portion of bud $\mathrm{I}_{1}$ to $\mathrm{I} 2 \mathrm{lnm}$. long, $+111 \mathrm{~m}$. in diameter, pubescent with appressed and spreading liairs, the free tips $+111 \mathrm{~m}$. long; hypanthium 2.5 to $3 \mathrm{~cm}$. long, pubescent; calyx-segments about half as long as the hypanthium; ovary $1 \mathrm{~cm}$. long; petals thick, to to $12 \mathrm{~mm}$. long, i i to $\mathrm{I}+\mathrm{mm}$. wide, deeply emarginate, not opening widely; filaments about I cm. long; antlers \& to 5 mn11. long; pistil shorter than stamens; stigmatic lobes erect, thickish, 3 to + mim. long (plate 21 ).

This description is based on plants raised from seeds sceured from Long Island (Bicknell, I904, and Vail, 1904) and grown two successive years in the New York Botanical Garden. 
The Linnean description reads as foliows: "OE: fol. lanceolatis planis, caule purpurascente muricato. Similis parviflorae, sed Fructus os non 8-fidis. Caulis puncta rubra sparsa. Canada." (L. Syst., ed. 12, 263. 1767.)

Based on this description and without reference to any later interpretation of the species, the following specimens are placed here:

Maine.-York, Bicknell, 1896 ; Cape Neddick, Bicknell, I896; Soutl Harpswell, Stevens, 1905.

1/assachusetts.-.Ipswicl, Morong, is 72; Nantucket, Bicknell, I899.

New York.-Long Island, Edgemere, Bicknell, 1902 and 1904; Coney Island, Vail, 1904; Staten Island, New Dorp, Kearncy, 1894.

O. muricata $\mathrm{L}$. raised from seed received from Professor De Vrics from the Holland sand-dunes resembled these American plants, but were not absolutely identical. This should also be said for some plants that were raised from seed collected by Professor De Vries near Chicago, Illinois, in 1904. Undoubtedly 0 . muricata has a wider distribution in the northeastern States than can be noted here.

In addition to these quite a number of plants that apparently are referable to this species are preserved in the herbaria of the New York Botanical Garden and of Columbia University. They are as follows:

Canada.--Province of Quebec, New Carlisle, Williams \& Fernald, I902; Rimouski County, Collins \& Fernald, r904; River Ste. Anne des Monts, Collins \& Fernald, 1905; Anticosti, Jupiter River, Macoun, i 883.

Massachusetts.--Provincetown, Hollick, I901; Nantucket, MacDougal, 1905.

Rhode Island.-Block Island, Hollick, 1897.

The Nantucket, Provincetown, and Block Island plants are probably stunted specimens merely, but the Canada specimens are quite remarkable in that the mature plant still preserved the remains of the rosette of the previous year at the base of the stem and in general appearance; even to the bent habit of the upper portion of the stem they can be easily identified with the plate and description of $O$. muricata in Flora Danica, pl. 1 757, I823.

An attempt was made to raise some plants from seed taken from Messrs. Collins \& Fernald's specimen from River Ste. Anne des Monts, 1905, but it was not verysuccessful. The plants were quite persistently biennial and in no case was a normal central stem secured, and the rosettes in the garden were very much larger than those on the herbarium specimens. The Canada plants are evidently a more northern form of the I,ong Island plant (plate 22).

The habit of the rosette of the previous year remaining at the base of the flowering stem of the second year's growth is one that is also claimed for his species $O$. ammophila by O. Focke (igot).

The plate of O. muricata published by Murray (Nov. comm. soc. reg. Sci. Goctt., 6:24, pl. 1, 1776 ) appears to have broader leaves than the American plants enumerated here. 


\title{
GENERAL DISCUSSION.
}

\author{
HISTORICAL, CONSIDERATIONS.
}

With the increasing attention being enlisted in the subject of mutations in organisms, numerous records of the saltatory activation and latency of characters in lines of descent are being disclosed by workers in all branches of biological science. Some observations published by Dr. Arthur Hollick in March, I879 (Hollick, I879) are among the most suggestive. The views expressed by Dr. Hollick over 26 years ago harmonize so well with the sum of information available at the present time that it will be profitable to give them in full in this place. He says:

The object is more to call attention to a few facts which seem to have been generally passed over in botanical researches as devoid of interest. The whole subject arranges itself under two heads. The first will comprise true "albinos" or such plants as have spontaneously, in a state of nature, lost their colors and become white flowered. The second relates to those plants in which the colors have been more or less eliminated by artificial means.

First, then, we have to consider those "sports" of nature where there has been a sudden change, without any intermediate steps, from a plant with colored flowers to a pure white variety; which change, for want of a better term, we may"call "spontaneous." Such may be aptly termed "negative" varieties, since their pecularity is due rather to an absence of their normal color than to the presence of white.

It is nothing uncommon to see, in many species, a gradual change from a brightly colored individual, through successive lighter and lighter ones, until a pure white is reached. This may be very well seen in Hepatica triloba, which comprises individuals of every shade from dark purple to white; or in Polygala sanguinea, in which we find the same gradual change from a dark red. ***

The following list of "albinos" is made from specimens collected during the last three years. Vernonia novaboracensis Willd., Lappa officinalis var. major, Lobclia syphilitica Linn., Epiphegus virginiana, Verbena hastata J,inn, Asclepias incarnata Linn., Trifolium pratense Linn., and Brunella vulgaris Linn. Both Gentiana crinita Froel. and Lobelia cardinalis Linn. have been reported to me as having produced at times albino forms, but $I$ have never seen them personally. ***

Now, in the first place, not only does the flower show the characteristic absence of color but the leaves, stem, and, in fact, the entire plant, are invariably of a lighter green; and if any red or green should be normal to the stem (which is often the case) this will also be of a lighter shade. $* * *$

Secondly, if we have under consideration a plant which commonly is known to have juice of an acid or peculiar taste, this is generally more or less absent in the albino form, and sometimes is eliminated entirely. Darwin has noted this fact, and, in commenting upon it, says that honey bees evidently are aware of it, for they perforate the calyx and corolla of the white Aconitum napellus, to get at the nectaries, but will not so do with the colored ones. ***

It has often been urged that these albinos are mere "sports" of Nature, with nothing constant about them; their peculiarities due, often, to growing in the shade, etc. In fact, that it is a condition due to bleaching or insufficient sunlight, and that there is nothing 
inherent in the constitution of the plant. Fortunately I have been able to test this. In the case of Lobclia syphilitica I first found the plants in the shade of some rather thick underbrush, in the montl of September. This growth was eut down the following spring, and the place opened to the full glare of the sun. This was done three years ago, yet, every autumn since, the plants lave cither reappeared, or else left offspring which have inherited their albino nature. This shows them not only constant in their peculiarities, but also that these are bred in the plant and capable of inheritance. Epiphegus virginiana and Brunclla vulgaris offer the same proofs. Nor lias the influence of locality much or anything to do with it, for a plant of the Lobelia syphilitica (with white flowers), which originally grew in a swamp, was transplanted to a dry garden a mile or more away, yet came up and blossomed white the next year.

Let is now see what the exferience gained in cultivation of white varieties can tell us. Perhaps the Japanese have bronght the art of eliminating color from plants to the greatest perfection. Scores of species and genera have been by then variegated in the most peculiar manner. But this is never constan in this comtry, but after a while always tends to revert to the primitive color again. ***

As there seems to be no tendency to reversion in these natural albinos, they might perhays be made permanent varieties and be valuable on that account. No doubt this permanence is due to the change being sudden, leaving no trace of color by intermediate steps, while in cultirated examples the white lias generally been obtained by a gradual selection of less and less darkly colored ones, and hence there would be a greater tendency to reversion back through thesc steps again.

From the foregoing it is elear that retrogressive white-flowered derivatives were seen to arise from colorerl parental forms by saltations in which the color of the flower behaved as a unit-character, and furthermore that the new colorless forms were constant and were not affected by environmental conditions. These ideas in fact underlie an inportant part of the nutution theory; and the statements by Dr. Hollick constitute the unexpanded thesis of the saltatory behavior of one set of characters. Not the least interesting part of the discussion is that which in effect recognizes the fact that many white-flowered and white-leaved forms in cultivation represent the extremes of fluctuating variations, and that when artificial selection lapses these forms gradually return to a normal mean; also that some speeies, such as Hepatica triloba, may also have an extremely wide range of fluctuating variability as to the flowercolors.

I dim realization of the importance of sports and of the necessity for some other lyypothesis besides natural selection toaccount for the existence of all living plants seemed to be widespread among botanists about the time De Vries began the investigations which liave led to his conclusions as to the influence of mutations. An interesting forecast as to the matter was made by the late 'Tlomas Meehan (Meehan, is 2 2). He said:

The conclusion I have been forced to is that the odd forms we often find in nature are not necessarily liybrids, but are as likely, if not more likely, to be the ontgrowth of some internal law of form with which we are as yet unacquainted. That they do not often perpetuate themselves is [not] remarkable whien we remember that of thousands of sceds produced on any one tree but a small percentage ever gets a chance to form, and of those which do sprout, 
again but a small percentage survives to beconle bearing trees. As the number of trees reproducing the general features of the original may be a hundred to one of the more strikingly aberrant forms, we may see that thugh iudividual instances may be common, we are never likely tomeet many trees of one stamp. Once in a while an individual tree may find itself in a sinution favoralle to the preservation of a number of secollings, which mighn endure until again reproductive; in such cases a marked variety may originate and mate its way wer the earth.

1 lave often thought it probable that in time a few individuals of these sudkenly introduced forms might again leap into new features, and then if they shonle be alde to strstain themselves we shonld have new species quite independently of any principle of natural selection.

The negative implied by the context is stpplied in brackets and indicated by italics.

The above are by no means to be the earliest formulations of the hypothet ical conclusion as to the importance of sports in phylogeny. Among others which might be mentioned the statement by Kerner in 1869 is worthy of citation. He says:

Die Arten die uns gegenübertreten, sind nur Stadien and haben als solche zwar für eine gewisse Zeit Konstanz, konnen sich aber frïher oder später in anders geformte Arten auflösen. Thatsache ist es, dass alle Pflanzen früher oder später cimmal vereinzelte Alarten, d. i. Sprösslinge zu erzengen in Stande sind, welche in iluren Merkmalen von der Hutterart abweichen, und zahlreichen Erscheinungen drängen uns zu der Annalume, dass unter den zusammentrefien günstiger Bedingungen solche Abarten die Ausgangspunkte netter Arten werden.

Among other recent observations is that of Schafiner (1906) concerning a derivative of Verbena stricta which bore pinkish-white instead of the deep purple flowers of the species. The aberrant form was present in many thousands of individuals among the typical specimens, with which it seemed to be in successful competition. Tests have not yet been made to determine whether or not it does not readily cross with the parental form, or whether it is dominant or recessive with regard to the more important differentiating character. In any case, however, its mutative origin is based upon evidence similar to that which zoologists seem willing to accept as proof of mutation in animals, and its successful maintenance against parental competition is an established fact.

Many of the observations brought forward by various anthors concern species which have been long under cultivation, and so many facts reporterl from hortictulural material have been found to be tnguarded against errors affecting purity of lineage that much prejudice exists with respect to data obtained from domesticated forms. So far as the effects of actual tillage or domestication are concerned, these prejudices are withont fonndation, since at the present time no well-founded evidence exists to show that cultural conditions have ever produced alterations which were strictly and continuously inheritable under environic conditions other than those by which the altera- 
tions were induced, although vague statenents and erroneous generalizations to the contrary are current. The possibility of such results is to be by no means denied, but if this view is to be upledd it must be supported by some evidenee based upon actual experinentation. Vicinism, the somatic multiplication of butel-sports and extreme variants, and the confusion of closely related clementary species form the basis for the greater number of positive assertions as to the effects of cultivation, and it is necessary to examine all facts bearing upon the lineage of stupposedly new forms with the greatest care before their aspect or behavior nay be taken as evidence npon phylogenetic problems.

An extended consideration of the phenomena of nutability has led the anthors of this paper to entertain grave doubts as to the practical value of the conception of periodicity. De Vries throughont his writings has favored the assumption, on purely theoretieal grounds, that a species must, at certain times in its history, be in a mutable condition, while in other periods of great length all of the progeny come true to the type, subject only to fluctuating variability.

It is quite possible that any given form may give off derivatives steadily for centuries, but none of the se being fitted to survive, no trace of this activity remains. A change in the character of the mutants originated, or newly found conclitions met with in comparatively short migrations, might readily give an appearance of the beginning of a mutative period, unless the matter hial been tested by pedigree-cultures.

With regard to the actual suceession of generations two aspects of the case present themselves. In one case it may be supposed that an annual species might have a limited distribution, and, occupying small areas, might be represented by only a few incliviluals every year. Combined with these circumstances, the proportion of mutants produced by the speeies might be so small that it wotld be possible to examine every specimen for a hundred years without meeting a single atypic individual. The conchision would then be reached that this was included in the immutable period. Then if the number of individuals grown and examined in the next ten years numbered as many millions, and some mutants were fonnd, the line of reasoning followed wonlt lead to the fallacions assumption that a mutable period lial begun, or rather that some physiological change had ensued in consequence of which mutations were occurring. These might as readily be seen during the lirst year of observation, however, if enough indivicluals had been grown.

It appears, therefore, that the real state of affairs is better represented by the phrase "frequency of nutation," by which is expressed the number of inclividuals which nust be grown to furnish one mutant, and which is nearly identical with "the coefficient" of mutability. If the parental type produces more than one mutant, the frequency of these may vary widely from each other. 
Thus of the great number of mutant individuals originated by 0 . lamarchiana but few have been mbrineris, still a smaller number represented gigus, while the combined observations at New York and Amsterdam have faited to bring brevistylis within the range of the eultures, this form having arisen at Hilversum, where it is still in existence. To secure mutants, or to allow a species to display its possible derivatives, the long stretel of eenturies may lee shortened and as many individuals examined in a seedling stage in a single season as might naturally mature in twenty decacles. The real point to be attained is to secure sufficient individuals to include the proportionate number of all the clerivatives.

ADDITIONAL, EIIDENCE AS TO THE DISTRIBUTION AND OCCIRRENCE OF I.AMARCK'S EVENING-PRIMROSE.

The records and material cited and examined show that a large-flowered evening-primrose, which can be identilied with nothing so closely as with (). lamarckiana, had found its way into the gardens near Haarlem, Holland, as early as 1756 , several years before 0 . grandiflura was brought from its habitat in Alabama to England in 1778 . Also that an evening-primrose with large flowers was seen on the sand banks north of Liverpool, England, in 1 So6, on the coast of Somerset in 1837 , and has been cited and deseribed by various authors in I845, IS5I, 1855, I 860 , and continuously since 1892. Plants grown from seeds obtained from the region in question proved to be (). lamarchiana with two of its mutants, rubrinerzis and late. Not only did this confirm the supposition as to the long history of lamarckinna, but it also showed that mbineris had successfully maintained itself in conpetition with the parental form, while late had becone capable of self-fertilization, the only instance on record.

THE MITANTS AND MUTABIITTY OF IAAARCK'S INENING-PRINROSE.

The observations begun by the Iries upon O. lamarkium in is 4 and continued upon purely pedigreed material hy hinself unt il the present tine, and the cultural experiments described in this paper, denonstrated a very high frequency of mutation in this species and also that the mutative depart ures show a great diversity when compared with other forms. In adclition to the derivatives which constitute the greater proportion of the atypic offspring gigas has recently reappeared in an example in New York, being one of the rarer forms. Then the sudden appearance of a totally new type among the mutants leads at once to the confumation of the suggestion that certain mutants may appear so infrequently that they might not be expected nore than once in a million individuals and consequently would not be seen except at long intervals.

Of the known mutants albida, oblonga, gigas, nanella, lata, and scintillans were found in the pedigreed cultures deseribed in this paper, and with greatly 
varying freguency. In one culture the coefficient of mutability of oblonga was pushed slightly beyond the limit hitherto assigned to it by De Iries and it was found to constitute $5+$ per cent of the atypic derivatives. A survey of all of the results obtained in the New lork Botanieal (aurden since 1902 does not justify the assertion, howerer, that any change in the fregueney of mutation has becn induced by cultural conditions, and the only really new feature noticed consisted in the appearance of a new nutant, which, however, was so unsuited to the climatic conditions that it perished before reaching maturity, an example of the climinative action of selection in the determination of what mutants shall survive and what shall perish.

Cultures made from seeds obtained from merchants did not show a frequency of the mutants above 1.5 per cent in any instance, which is much less than that observed in the strain growing at Hilversum. The sources from which the seeds were obtained indicate that the species is in a state of mutability in varions parts of the world, and that it has probably been so for some time. The low frepuency of mutation may have been due in part to unsuitable methods of cultivation, in consequence of which the parental individuals were badly nourisled.

0 . brizistylis was brought to nuaturity and found to agree in all characters with specimens grown in Amsterdam. This form differs irom the parental type chiefly by the retrogressive character of a shortened style, and by gencral olsservation this organ shows a wider range of fluctuation about its average than the sane organ in the parent, although no exact examination was made. I) spite the fact that this type produces comparatively few seeds it was found by I I ries among the individuals of the parental type in the original locality in which mutation in lamarkiana was observed in 3886 , and it has since held its own in competition with the parental type, in a manner demonstrative of the fact that it is possible for a mutant to survive in competition with existing forms.

(). lata grown from seeds obtained from Professor De Vries and from individnals arising in the pedigreed strains in New York was seen to remain constant to its characters. A few tests had been macke both in New York and Amsterdam, but no fertilization was secured with its own pollen, although some of it appeared structurally perfect in a microscopic examination. O. lata appearing in a culture from seeds of O. lamarckiana from Iingland, however, included some individuals which likewise produced pollen, and also slowed the hitherto unknown capacity of being fertilized by it. 'lhe seeds obtained in this way gave rise to a progeny which showed only the constituents usually found in a progeny of this plant when fertilized by lamarckiona.

O. scintillans grown directly from its own seeds, and also as it appeared as a new mutant in the cultures, was constant in its ever-sporting character. Seeds of this species purely fertilized gave rise, in adclition to the type, to a few 
individuals of oblonga and lamarckiana, in addition to an unrecognizable form, the representative of which did not reach maturity. Purely fertilized seeds of this form have also been seen to give rise to lata and namella.

O. oblonga was grown direetly from its own seeds and also appeared in all of the cultures of the parental type which were spread sufficiently to include its coefficient of mutability. It appears to be constant in its characters and is strikingly differentiated at a very early stage of its development.

O. albida was also grown directly from its own seed and appeared in the pedigreed cultures of lamarckiana. It appeared to coincide in all of its characters with the descriptions given by De V'ries.

The single test which was made of the effect of crossing the parental type, lamarckiana, with one of its mutants, mbrinervis, gave results in accordance with the conclusions of De Vries in this matter. Rubrincrvis is a mutant of supposedly low frequeney of occurrence, since it has not been found in any pedigreed culture for several years. It may be regarded as a progressive derivative of the parental type and presumably carries all of the lamarckiuna qualities in a latent condition. On the other hand, the strain of lamarckiana with which it was crossed, and from which it was derived several generations back, must bear the characters which gave rise to this form as a mutant. The two plants must therefore carry the same characters, but some are latent in one and some in the other.

The origin of species by hybridization, which has been a well-recognized phenomenon for half a century, receives further exemplifications in crosses between $O$. cruciata and $O$. lamarckiana. The fixed forms which may be produced by this cross have been cultivated in European gardens for some time under the names of $O$. cruciata, O. cruciata varia, and O. bicnnis cruciata. The list of species which have originated by hybridization is a long one and need not be recounted here. Singularly enough, this fact seems to be unknown to workers who carry on extensive operations in plant breeding. In the instances cited in this paragraph, the most remarkable feature is that a fixed form or new species may be produced by the hybridization of two parental types of comparatively high frequency of mutability. It seems also pertinent to again sound a warning against the continued practice of taxonomists of ascribing liybrid origin to species, with characters apparently intermediate between two neighboring and known forms. Numerous hybrids of known origin in the New York Botanical Garden have been submitted to competent taxonomists, and in no single instance has a correct diagnosis of the parentage been made.

The fertilization of the eggs of lamarckiana from the pollen of rubrinervis resulted in a single observation in a progeny which contained $7 \mathrm{t}$ per cent of the latter, or mutant, type. This is not a universal result, however, since the proportion has been found to vary from 19 to 74 per cent. The pollination of O. bicnnis by the mutant described in this paper gave a progeny in the first 
generation which conformed to the biennis type. The same result is true of the reciprocal cross. It remains to be seen whether the nutant characters are merely recessive in this combination, or whether a condition of latency has been assmmed in which the mutant appears only in its customary frecueney.

The evening primroses, then, afford the following exact eviclence as to the effects of intererossing: Many of the mutants when crossed with the parental form give progeny composed of the parental form and the mutant in the first generation. In the case of gigas and rubrinerits the proportion of the mutant in the progeny is generally much higher than the parental type. Rubrineris when grown in close contiguity to the parental form showed only a small proportion of crosses, and the newly discovered mutant of (). bicnnis also gave but a small proportion of crosses when exposed to danger of hybridization with the parent. Iastly it is to be pointed out that O.brezistylis, which produces but few seeds, and which is recessive when crossed with O.lamarckiana, has been in continnous existence for 20 years, perhaps much longer, at Hilversum, where it is in direct competition and danger of being hybridized with the parental form. Experiences in the guarded cultures seem therefore to be confirmed by an analysis of natural conditions. Swamping of new forms, by intercrossing, is a specter which looms vast and shadowy across the visions of writers of a speculative habit, but at the present moment it is believed that no evidence carefully tested by modern methods is available to justify the hy pothesis, so far as plants are concerned.

The demonstration of the greater variability of the mutants as compared with the parent form seens to be complete, and this relation is one of considerable practical and theoretical importance. The greater variability of plyylogenetically new characters as compared with older ones is not wholly new and unique, though we believe our studies in root gave the first statistical support to the thesis when stated in this form. Darwin's (I 859 , Ch. II) view that characters which distinguish species are more variable than those that separate genera, and that varietal are more variable than specific characteristics, gives the first recognition of this principle, if we take into acconnt that according to his conception of the relation of these several form-groups the variety is an incipient species and the species an incipient genus. Iiield (1 SoS) worked out the relation between a varietal and a specifie characteristic in the wings of a lepiclopterous insect, giving a confirmation of Darwin's rule, but he did not relate his facts in any way to the relative age of the characters studied. It is probable of course that the varietal characteristic was a more recent acquisition than the specific, and this would nuke his results accord well with the observations of the authors on Oenothera.

to the student of evolution who wishes to institute pedigree-cultures, the relation here demonstrated should prove of much practical value, for it matters not whether he desires to study the possibility of fixing extreme fluctuations, 
or whether he is engaged in tracing the character, frequeney, and causes of mutation a preliminary statistical investigation will aid in the choice of material best suited to his purpose. It is obrious that the great variability of any clementary species would disfavor it as research material for the study of mutations rather than indicate its desirability, as the wide range of its fluctuations would suggest the likelihood of its being a recent mutant rather than a 111utating species. A more promising procedure with respect to any variable form would seem to be to use the most nearly related or contiguous species liaving a low degree of variability in the hope of thus hitting 11 pon the parental type from which the variable form originated. The student of pedigreecultures frequently receives letters from the kindly disposed, calling his attention to strikingly variable forms which are, on the ground of their variability, conceived to be especially valuable. It is to be hoped that in the future more attention will be given to constant forms having one or more variable near relatives.

Whether the relative variability of old and new structures could likewise be used by the morphologist as a new criterion for working out lines of descent it would be somewhat reckless to say at present, but an important field for research is indicated. Are forms which are obviously more recent at the same time more variable than the older? Are the structures characteristic of the Orchidacex, for instance, more variable than those of more generalized monocotyledons, and those of the Compositæ more variable than those of other dicotyledons? Are monocots on the whole less variable than the dicots? While not wishing to press the application of the principle too far, it may be pointed out that one feature of the investigation here reported seems to bear directly upon the phylogenetic significance of the greater variability of new characters. 'The characteristic feature of the Oenother bud is the hypanthium. It doubtless represents one of the most fundamental mutations in the history of the genus. It accords well with the hypothesis here offered to find that the length of the hypanthium is in every species the most variable part of the bud. The great excess in its variability over that of other parts of the buds is made strikingly apparent by comparing the average variability of the several parts of the buds in all the species studied. The average coefficients of variability are as follows, in order of their magnitude: Length of hypanthium, 14.97 ; length of cone, 9.56 ; length of ovary, 8.66 ; thickness of cone, 7.85 ; thickness of ovary, 6.30; thickness of the hypanthium, 5.83. The consistency of these results make it certain that the great variability of the hypanthium originated with the origin of the hypanthium.

The fact that a new species is more variable than an old one siould also give to the phytogeographer a method of investigating the exact status of an endemic species. If it presents a case of initial endemism it should be more variable than the nearly related, wide-ranging, and hence presumably older 
species. If on the other hand it is a local relict of an old species, which once hat a wide clistribution, it should present less variability than its wide ranging, presumably newer relative. The only satisfactory evidence heretofore available for deternining a point of this kind has been (Irawn from paleontological sources.

To the metaphysician who is striving to pieture to himself the laws of vital motion, the results of these statistical studies will give an altogether new view of the relation between fluctuation and mutation. Rosa (1899) has published a treatise in which he contends that there is a progressive lessening of variability during the progress of evolution, and he sees as the certain result of this process the ultimate extinction of life. Plate (1904) takes issue with Rosa on this point and maintains that there is no such law. The demonstration that there is greater variability in new species, conpled presumably with a decrease in variability as the species grows older, inclicates that both Rosa and Plate are partly right. It is now seen that although the individual speeies may decrease in variability as it grows older, this decrease is compensated for every time a new species springs into existence. Instead of mutations being the cumulative results of ever-increasing fluctuation, they appear now as an initial process of which fluctuation is in part an after effect.

A detailed description of but a few of the species of Oenothera have been given. Seeds and ntaterial have been brought in from all parts of Ameriea east of the Rocky Mountains, and a consideration of this material gives foundation for the conclusion that under the name bicnnis is inchuled a swarm of elementary species very closely related, but easily distinguishable when grown side by side, having no intergrading forms.

Even the inperfect knowledge we possess of the species, owing to the scarcity of collections made of them, shows that they overlap in distribution in the most haphazard manner. In the same way, the clementary species comprised within cruciata interlock. In tiscussing the principles that govern distribution, it is to be admitted that in accordance with their usual practice many systematists would not allow specifie rank to the forms in question, so closely are they related. It will be in order, therefore, to take up the next grouping of interest, that of biennis, and the allied species of oakesiana, paraiflora, muicata, and cruciatu, which were accepted as varieties of biennis 30 years ago, but which are aceorled specifie rank at the present time. It is found that biennis blankets nearly the entire range of these forms, and also that the ranges of these forms overlap among themselves. It is to be seen, therefore, that no matter what range of opinion may enter into the diseussion as to the rank of the forms of the evening prinroses of the eastern part of North Anerica, the thesis that the most nearly related species do not overlap in distribution is unsupported. 
A condition similar to the above has been found in crotucons by Sargent \& Peck, who say (1906):

The peculiar tendeney of Cratuegas to flock together is strikingly illustrated in our ternitory. It is rare to find any large area occupied loy a single species. Where many thom trees and bushes grow together there are usually many species. A remarkable cxumple of this kind is found in a narrow strip of pasture land bordering the lirie Canal near Nenands. llere 10 species are growing in an area of about 1 acre. The closest conclensation of numerous species that I have seen anywhere is near Albia, where o if our native species are growing in a kind of irregular row along the west bank of the IIyantskill Creek. The length of the row is about roo feet. It is worthy of remark that 3 of these species, C ruthegus forentaria, C. rhombifolia, and C. succulenta, belong to the group 'Tomentosa. Sich close associations of niembers of a single group) as this one at Iansingburg are very significant and when nure fully understood nuty possibly throw some light on the interesting problem of the developnent of species.

Other students of the thorns have found similar conditions with strains which were found to be distinet and hereditary in pedigreed cultures. Here, again, if a conservative view is upheld and specific rank is not accorded these clearly separable elementary species, a similar association of the closely related group species may be found. A similar condition among the opuntias has been noted by the author. These facts make it conclusive that the assumption that the nearly related or most nearly related species of a group do not occupy the same habitat is untenable.

Two bud-sports of different types as to origin were found during the summer of 1905 and tested as to their hereditary qualities.

The vegetative mutant branch of ammophila was seen to give rise to a progeny which came true to the characters of the branch producing the seeds from which they were grown, and the reversion, if it is such, may be considered complete. If, as suggested, ammophila is a hybrid and the sport is a reversion to one of the parents, then this case may be taken to agree with that noted by De Vries (1900, p. 86), in which a hybrid of two forms of I'cronica gave off bud-sports, which in purely fertilized seeds came wholly true to one of the parental types. In thiscase the sport was a reversion to the ancestral qualities which had become latent when the lybridization was effected.

The second bud-sport was one in which the recessive characters appeared on a branch in the first generation of a cross, and when this was purely fertilized slowed only a strict inheritance of the recessive characters.

The facts offered by but-sports have much significance as to the localization of mutations, and as to the nature of the stimuli which set the mutatory processes in action. Primary buds usually arise laterally from the tip of the growing point and within a millimeter or two from its apex. The saltation, of whatever character it may be, occurred in a cell or cells in the cubryonic tissue while the growing tip was moving 11 pward a distance of a nillimeter or more. Much depends upon the place where this occurs. If it is possible for a 
single cell near the apex of the growing point to undergo sucl clanges during the rapid division that characterizes this region that it gives rise to a mass of cells from which the bud arises, this would favor the probability that the saltatory changes are due entirely to internal canses and might not be affected at all by circumstances.

liximples of sports are known in which a section of the sloot involving several branclies are of an atypic character. De Vries offers an illustration in his deseription of a green branch on a colored oak in which the greening not only affected the entire branch, but also a section of the nember from which it arose, showing that the mutated protoplast was one which gave rise to more than the at ypic branch. In other instances the mutation may involve only a longitudinal section of a branch or of a member or limited growth such as inflorescence, and this may be carried to the extent that even half of a flower nal be of an atypic character, and likewise similarly complex frnits may be prodincel. It is, of conrse, admissible that in reversionary sports, as most of these seetional variations are, the qualities that appear in the sport are latent in the entire plant and need but a slight stimulus to awaken them, or some force to weaken the dominancy of the main stock. So far as the saltation here is concerned it is one in which any disturbance of the equilibrium would in all probability have but one restilt.

In the case of the appearance of characters not inherited in a latent, recessive, or active condition, but which constitute a progression or acquisition, the case is lifferent, and if more than one protoplast is concerned in the alterations ensuing preliminary to the organization of a but-sport, then the suggestion that the alterations were the result of stimulation from factors external to the cell in which the changes custued would have great force.

Bud-sports usually occur on the lower part of the main stem, where many of them lie dormant in slecping buds, and may be awakened by decapitation of the shoot. It is thus to be seen that they belong to a comparatively early stage in the life of the sporoplyte. The mutations which give rise to atypical seedlings, on the other hand, seem on theoretical gronnds to be due to changes ensuing in the very closing stages of the sporoplyte, and previous to the qualitative or reducing divisions which form the egg, or in the early stages of the pollen mother-cells. Here is encountered a feature not yet recognized in budmutations - that of a fairly constant frequency.

No evidence has yet been secured to show that the pressure or direct action of environmental factors upon the regetative organs has produced any permanent inheritable changes in elementary strains of plants. The record of the experinents in which solutions of various kinds were injected into ovaries innmerliately previons to fertilization secms to point definitely to the conclusion that the bearers of the hereditary characters may be definitely and directly affected by forces external to the cell, however. The alterations thus 
induced consist in the suppression of sone qualities of the parental fornu and the substitution therefor of other characters with which the suppressed features are mutually exclusive. The clianges are expressed in anatomical alterations and nodifications of attendant functions.

Atypic derivatives have been secured in this manner from two species, Raimannia odorata and Oenothera bicunis, by the use of more than one reagent, as described in the preceding text. The induced mutants have been tested to the second and third generation, with the result that both are found constant in the sense that they do not intergrade back to the parental form.

The in jeetion of the solutions into the ovaries results in the total destruction of some eggs by the mechanical action of the needle and of the solution itself, while in a few the stimulative or other action is of such nature that the changes are induced which result in the modification of the hereditary characters and of the adult sporophytes which carry them, while doubtless in nost of the cases no action at all resulted. Of course in some of the unsuceessful tests all of the ovules were destroyed and fell of before maturity. While it seens more natural to assume that the injection results in direct action of the fluids on the egg-cells, yet the possibility is by no means excluded that the saturation of the tissues of the ovary with the solution results in the induced effect being due directly to the action of the reagent upon the advancing pollen-tube and its contents.

The wide variet y of substances used as reagents in securing the alterations in question nakes it impossible to suggest the nature of the changes induced in the reproductive clements, since the actual cffect may be osmot ic or chemical. Neither may it be said whether the changes consist in disturbances of the processions of enzymatic action, or actually modify the structure and composition of the cytoplasm or nuclear constituents.

Nutants have thus been produced by conditions brought about in an experinental way, and it can not be denied that similar action of external forces might occur unaided by man. The radioactivity of spring and rain water, or the effects of corrosive or other gases which are being set free in numberless places on the earth's surface, might produce effects sinilar to these obtained in the pedigreed cultures. Undue or ahnormal secretions from the walls of the ovary, from neighboring tissues, or from intruding foreign pollen incapable of accomplishing fertilization might excrt a similar influence. The stings and lacerations of insects and animals and the action of parasitic fungi are known to be accompanied by the liberation of certain substances, the activity of which results in profound changes in the somatic tissues. It is not unreasonable to suppose that the effect of these substances npon the ovary might exert equally important changes in the egg apparatus or developing ovules. In its present state this investigation appears to be of great potential impor 
tance, since it offers the suggestion that we may become able, more or less at will, to modify existing streams of heredity and cause new organisms to arise.

The point not to be lost sight of is that the action of external agents as described and deemed possible is not through the somatic tissues to the egg or germ-plasm, but is exerted directly upon the reproductive elements themselves. To assume that such action is stimulative, as has been done by Tower in discussing the earlier announcement of these results (Tower, 1906), is to adhere to one of a number of allowable suppositions-one, however, which seens most applicable to the results secured by him with beetles, but one to which we are by no means confined in the consideration of the induction of the atypic forms in plants. 'The determination of the character of this action constitutes one of the most difficult problems in connection with the entire matter. 


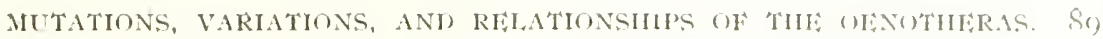

\section{RECAPITULATION.}

The principal features of the foregoing paper may be stated in the following brief generalizations:

(1) The probability of the origination of new elenentary strains of plants arising by saltations or sporting is one which has received the support of many authors, from inferential conclusions based upon the exanination of living material. It has also been found by more than one worker that elaracters aequired in a saltatory manner are not swamped by intercrossings. If such characters behave as units they may well survive, whether dominant or reces sive with respect to the corresponding charaeter of the parental stoek, the probabilities for survival being somewhat greater with recessive characters.

(2) Frequency of mutation is put forward as a better cxpression than periodicity of mutation for the proportion of salts oceurring in the course of generations.

(3) An evening-primrose inseparable from O. lamarckiana occurred aromnd Haarlem, Holland, as early as 1756 , and near Liverpool, England, in s Su6. It has been noted in this and other districts at various tines, and has been under more or less continuous observation since 1892. Apparently established and growing with it are $O$. rubrinervis and $O$. lata, two of its mutants. O. brevistylis, another mutant which is recessive when crossed with (). la marckiana, has been in existence in competition with the parental form in Holland for twenty years.

(4) The coefficient of mutability of Oenothera lamarckiana has not been increased in the cultures in America, although a form which has hitherto escaped observation was secured. Seeds of this parental form, from various sources outside of Amsterdam, furnished a smaller proportion of mutants than the material furnished by Professor De Vries.

(5) (). oblonga has been found to constitute as much as $5+$ per cent of the atypic derivatives of O.lamarkiana. O. lata, from material grown in Fingland, was found capable of self-fertilization and gave rise to a progeny containing the same elements as when fertilized by the parental forn.

(6) Fixed hybrids constituting species were secured in combinations of O. lamarckiuna and ( . cruciata.

(7) The greater variability of phylogenetically new claracters as compared with older ones, which was supported by statistical evidence brought forward in a previous paper, is confirmed by the evidence presented by furtler studies.

(8) The forms which would appear to promise most of inportance in a pedigree-culture would be species with a low degree of variability, liaving nearly related forms with a high degree of variability.

(9) The hypanthium of Uenothera, which seems to be a recent derelopment, is more variable than any other feature of the bud. 
(10) The inference seems justifiable that individual species become less variable as they grow older, and that this decrease is compensated for by the fact that when a new species springs into existence, it lias a greater degree of fluctnability than its parent. Such saltations are the starting-points from which series with deereasing fluctuation follow.

(11) O. pariflora, which has been known in Europe since 1759, has been found in its native habitat in America in the same manner that $O$. grandiflora was traced to its original habitat. 'This leads to the hope that O. lamarckiuna may be found in a wild state.

(12) The species of evening-primrose of eastern America are distributed in such manner that the most closely related species overlap in distribution. This conclusion is true, no matter upon what taxonomic basis the forms are classified. Sinitar conditions in Cratacyus and Opuntia are cited.

(13) 'Two bud-sports have been followed through two generations and found to be constant. 'The sport in one case embodied the recessive characters of a hybrid combination showing alternative inheritance, the recessive qualities being thus activated and extracted in the first generation, coming true thereafter.

(14) The action of reagents having an osmotic and a chemical effect has resulted in the induction of mutants in the progeny of Raimannia odorata and Oenothera biennis. The mutants thus induced have been tested to the second and third generation and found to come true to their newly assumed characters.

( 15$)$ 'The induction of mutants by the action of reagents is a conclusive demonstration of the fact that hereditary characters may be altered by external forces acting directly upon the reproductive mechanism. The action of the reagents used experinentally is simulated by many conditions occurring in nature. 


\section{BIBLIOGRAPHY.}

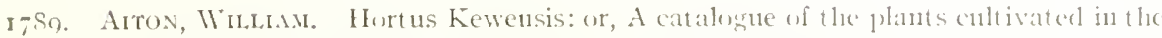
Royal Botanic Carden at Kew, 2, 2. Ismdon, 1 - Thos.

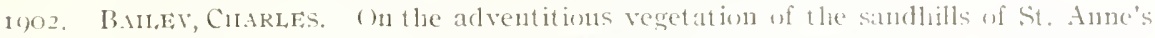
on-the-Sea, Nortl Lancashire. Mem. and I'roc. Manclester Lit. and I'hil. Suc., 47: jt. 1, 1902.

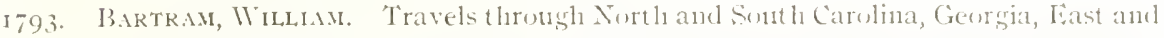
West Iilorida, the Clerokee country, the exteusive territuries of the Muscogulges or Creuk Confederacy, and the enuntry of the Chactaws. Inulin, 1 793. (Reprinted from the Philadelphia editiofs of 1791.)

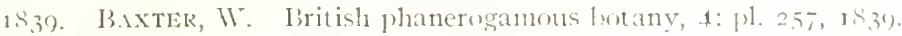

I\$59. D.1RWIN, C. ()rigin of species.

1900. De Vries, H. Das Spaltungsgesetz der Batstarde. Ber. d. dent. Drot. Cesell., Is: $8,3-90,1000$.

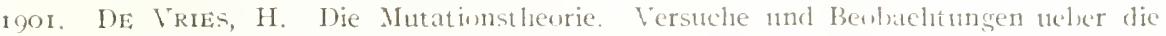
Fintstehung von Arten im Planzenreicls. Firster Band. Tie Fintstelung der Arten durcli Mutation. 6fs pp., s pls. Ifeipzig, 1001.

I902. DE VRres, H. Die Mntationstheorie. Versucle und Benbatutumgen ueber die Entstelung der Arten in Planzenreicl. Zweiter Iamul. Ite Bastardirnug. Erste Lieferung. 1ग. I-2 fo. I.eipzig, 1902.

I9O3. DE VRres, H. Die Mutationstleorie. Versuche nnd Benbaelitungen neler die Entstelung der Arten in Phanzenteich. Zweiter Band. Elententare IBastardlehre. pp. $24 \mathrm{I}-7.5 \mathrm{t}+$ pls. Leipzig, 100,3 .

1905. DE Virtes, H. Species and varieties: Their orimin hy mutation. Jislited lsy

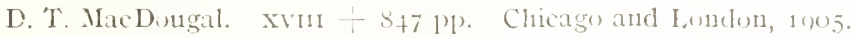

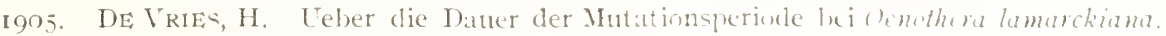

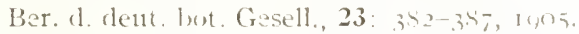

ISgS. IFELD, II. L. W. A contribution to the stuly of indivilual vartation in the wings of Lepidoptera. Proc. A. A. A. S., 33:3\$(3)-306, 1sigs.

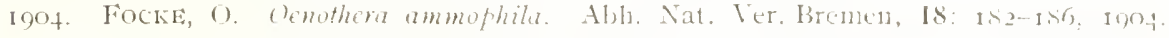

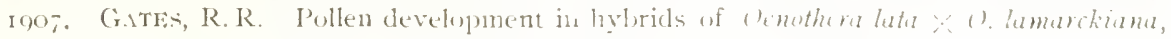
and its relations to mutation. Bot. Caz., $43: 4$ I- $15,5,-$.

IgO2. GREEX, C. T. The flora of the I,iverpoul District, P. .5, ronz.

1\$45. HALL, T. B. Flora of I iverpowl, 37, I\$4.

1s79. Holdick, Arthlr. A few notes on the abnormal absence ob color in plants. Bull. Torr. Bot. Club, 6: $293-206$, is; -9 .

1\$69. Kerner. Die Abhängigkeit der Pthanzengestalt von Klima nud Buclen. Inusbruck, $1 \$ 60$.

1903. MacDocral, D. T. Mutations in plants. Anerican Naturalist, 37: 7.37-770, Novemler, I903.

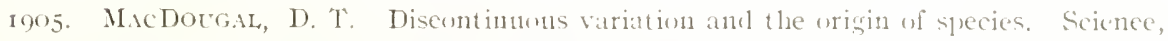
21: 20-23, I005. Also Torreya, 5: Ja11, 1-5, 1005.

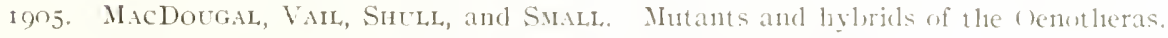
Publication 24, Carnegie Institution of Washington, Juns.

1905. HacDougal, D. T. The evolution of plants by mutation. Lecture before the Barnard Botanical Club, New Tork, December 1s, ians. Clicago, rgos.

I 906. MacDoug.1L, D. T. Discontinunus variation in pecligree-enlturea, Pop. Sci. M'thly, September, igo6. 


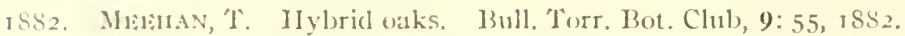

1,60. MuLl:k. Figures of the most useful and uncomnnon plants deseribed in the Cardener's Dictionary exhibited on three lundred copper plates accurately engraven after drawings taken froun nature, vol. 11,1760 .

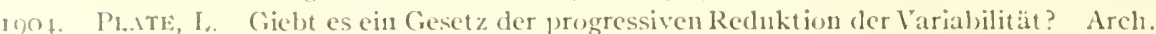
f. Rassen 11. Ciesells. Biol., 1: $6 \uparrow 1-65.5,100 \%$.

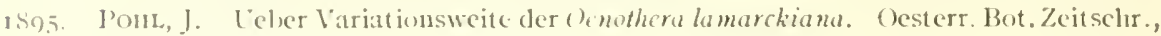
$45: 160-160,205-212,1595$.

1.S9o. Rosi, D. I a riduzione progressiva della variabilità, pp. 13.5. Torino: Carlo Clausen, isoy). (lirench Abstract, Arch. Ital. de Biol., 33: $31+$ et sey., 1900. German translation by Dr. H. Bosshard.)

I 003 . Ros. D, D) Lie progressive Reduktion der Variabilität und ihre Beziehungen zum Aussterben und \%ur Fintstelung der Arten, Pp. 105. Jena: Gustav lïisclier, 1903.

1905. Rose, I. N. Stuclies of Mexican and Central Anerican plants. 4. Contributions YY. S. Nitt. Herb., 8: 3.30, 190.5.

Igo6. S.IRGENT, C. S., and I'ECK, C. H. Species of Crataegus found within 20 miles of Albany. X. Y. State Museum Bulletin No. 105. Report of the State Botanist, 1905.1006.

19o6. Schaffere, J. H. A successful nutant of lerbene without external isolation. ()hiso Naturalist, 2: 31, 1006 .

ISo6. Smit, J. I:. Finglislı botany, pl. $1534,1806$.

1 gof. Towtir, IV. L. An investigation of the evolution of the clirysonelid beet les of the genus Leptinotarsa. Publication 48 , Carnegie Institution of Waslington, 1906. 

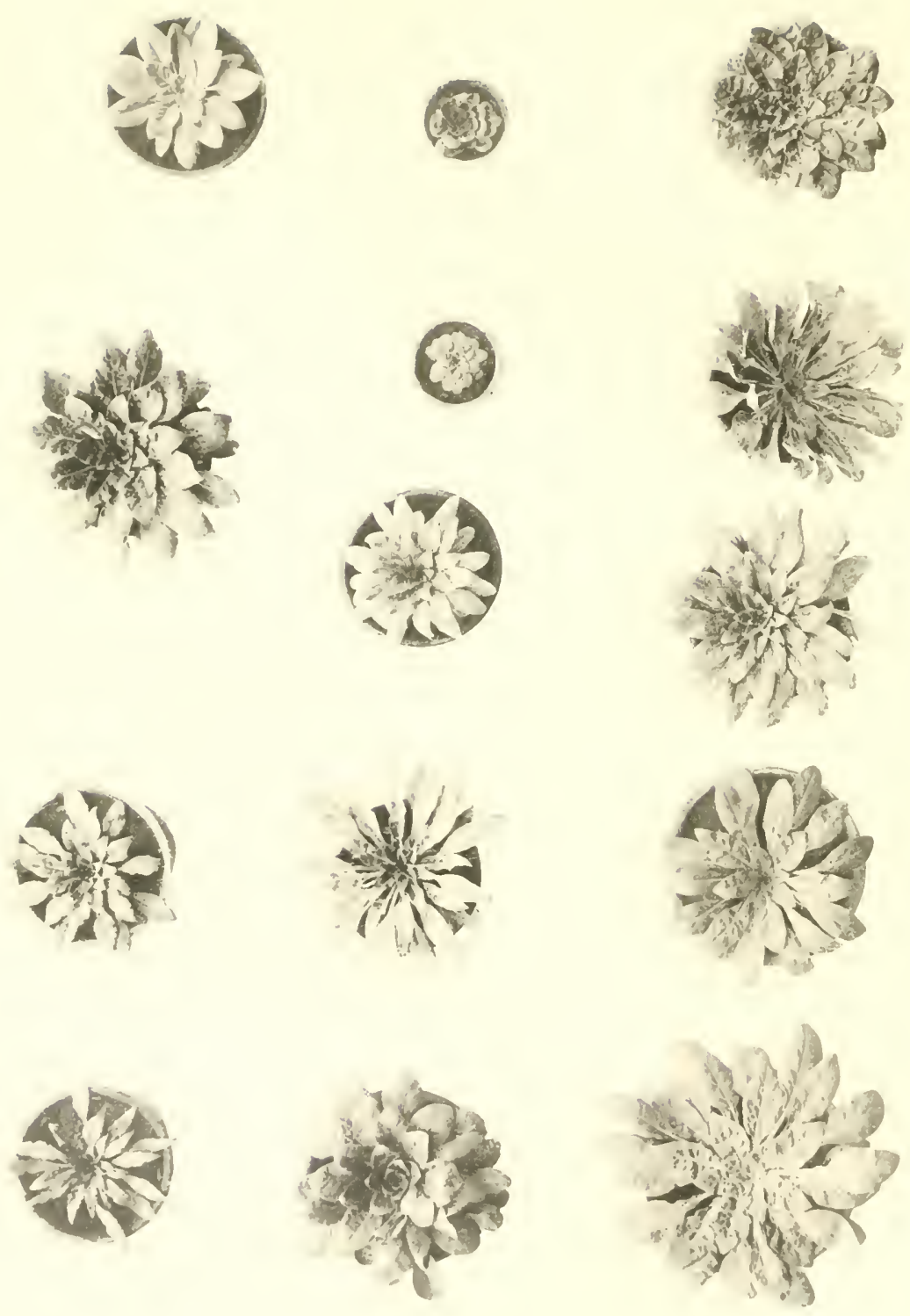
PLATE 2.
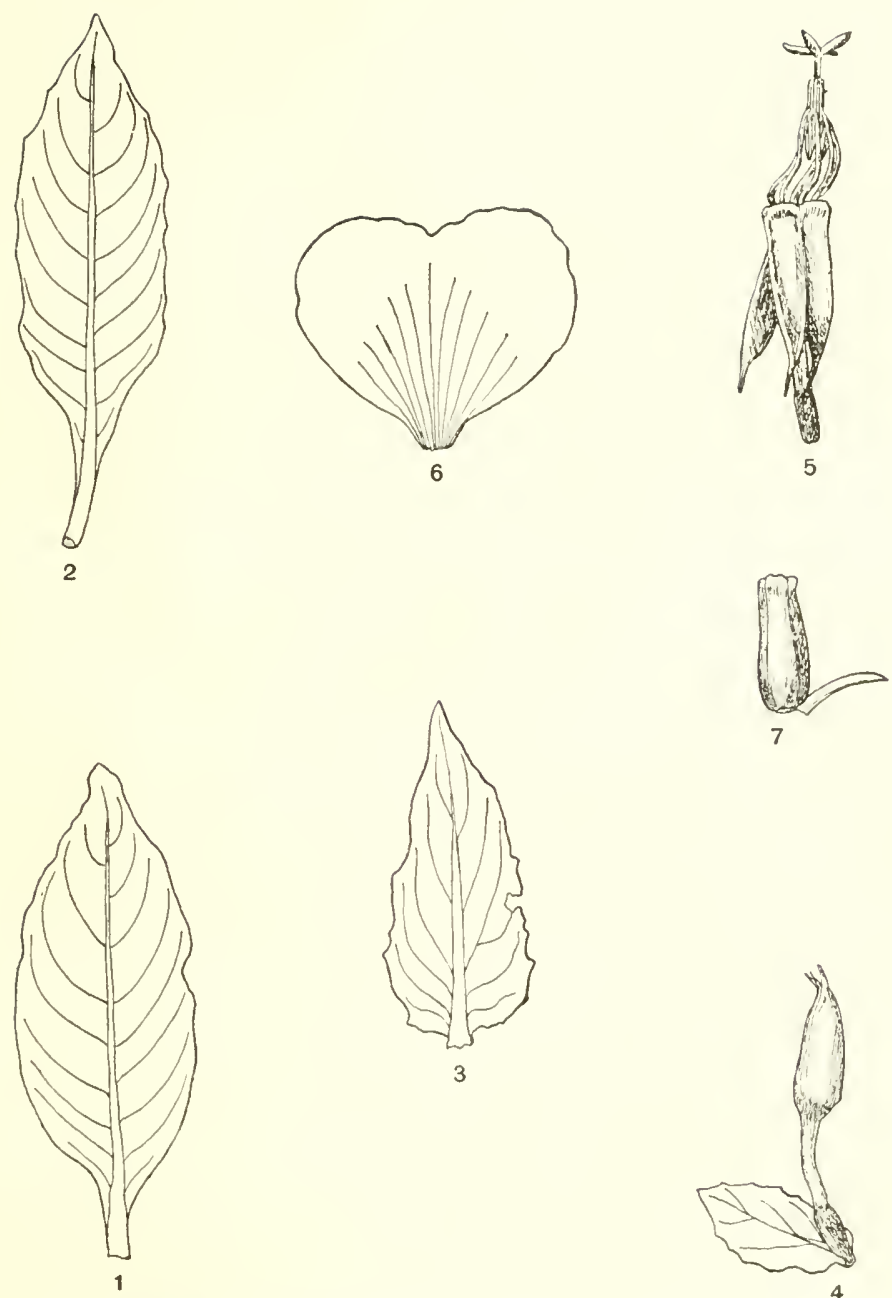

Ocnothera scintillans. 1, leaf from rosette; 2, leaf from stem; 3, bract; 4 , bud with bract; 5 , flower with petals removed; 6 , petal; 7 , capsule. 

PLATE 3.
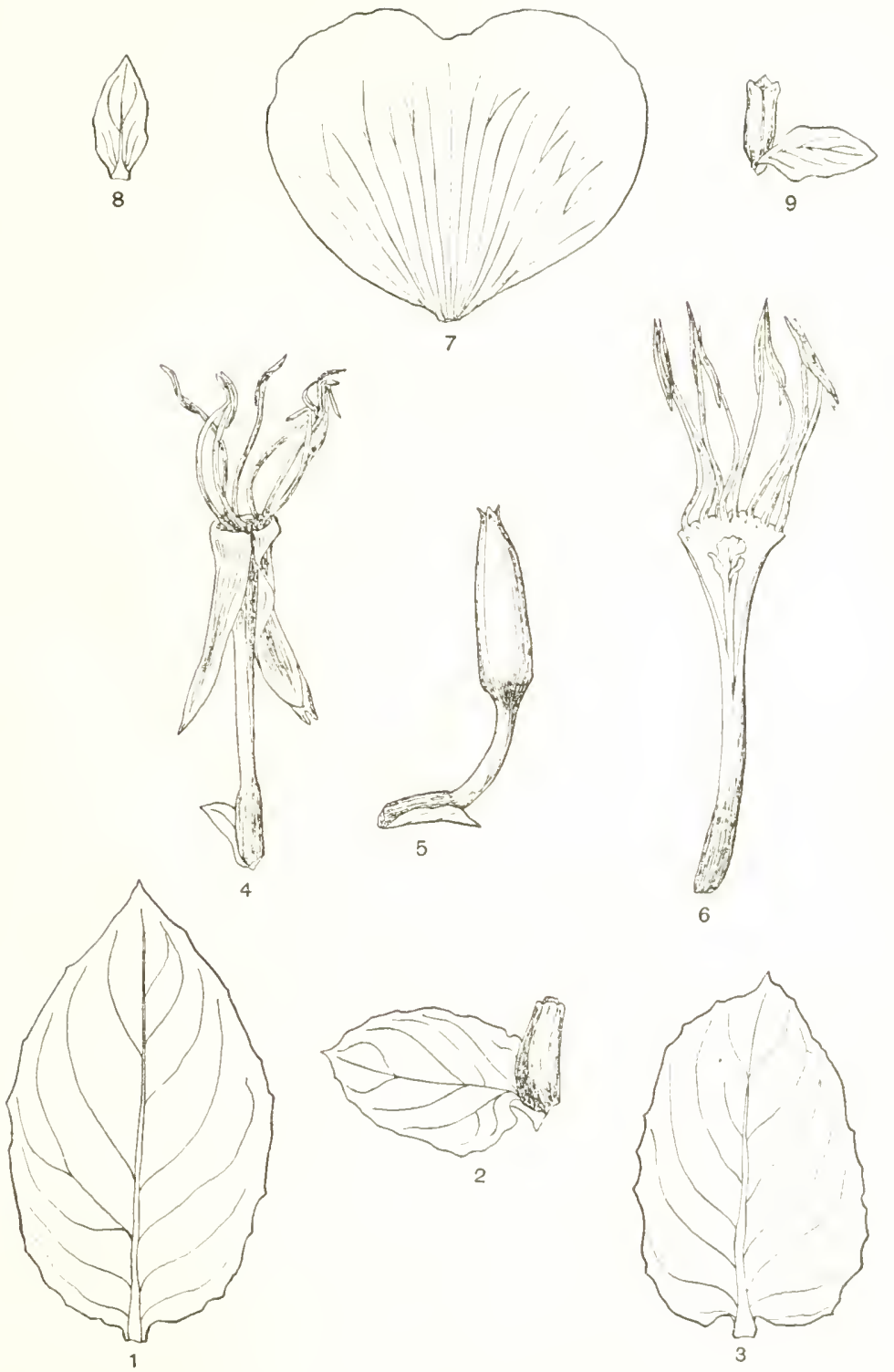

Oenothera brezistylis. 1, leaf from mature rocette; 2, bract and capsule; 3, stem leaf; 4. fower with petals removed; 5, lud; 6, hypanthium split open, showing the short, imperfect style; 7 , petal; $S$ bract; 9 , capule. 


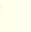




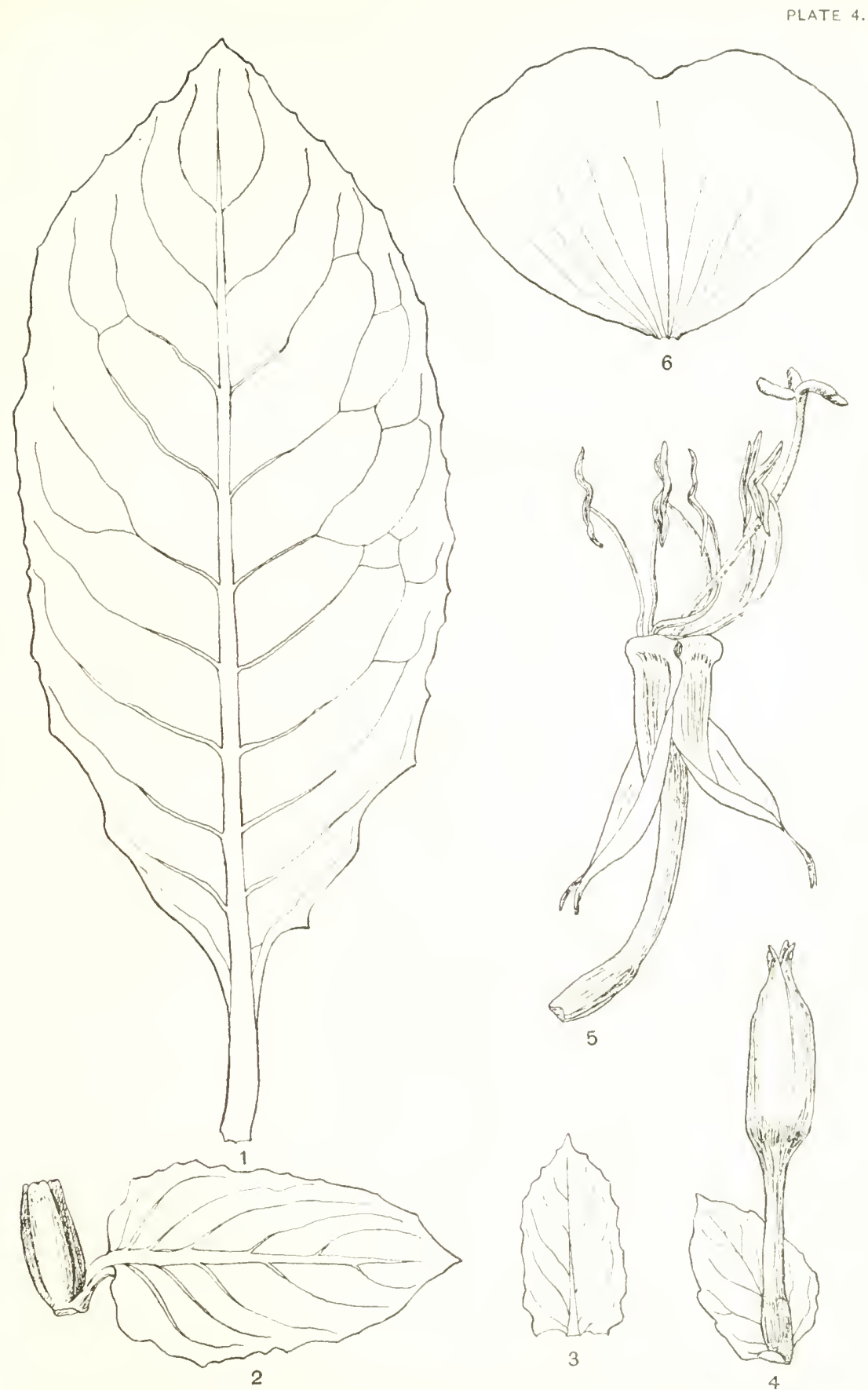

Onothera lata. 1, leaf from mature ronette; 2. bract and capunle, 3, bract; 4. bud and brazet 5 , flower with petals tikea off; 0 , petal. 


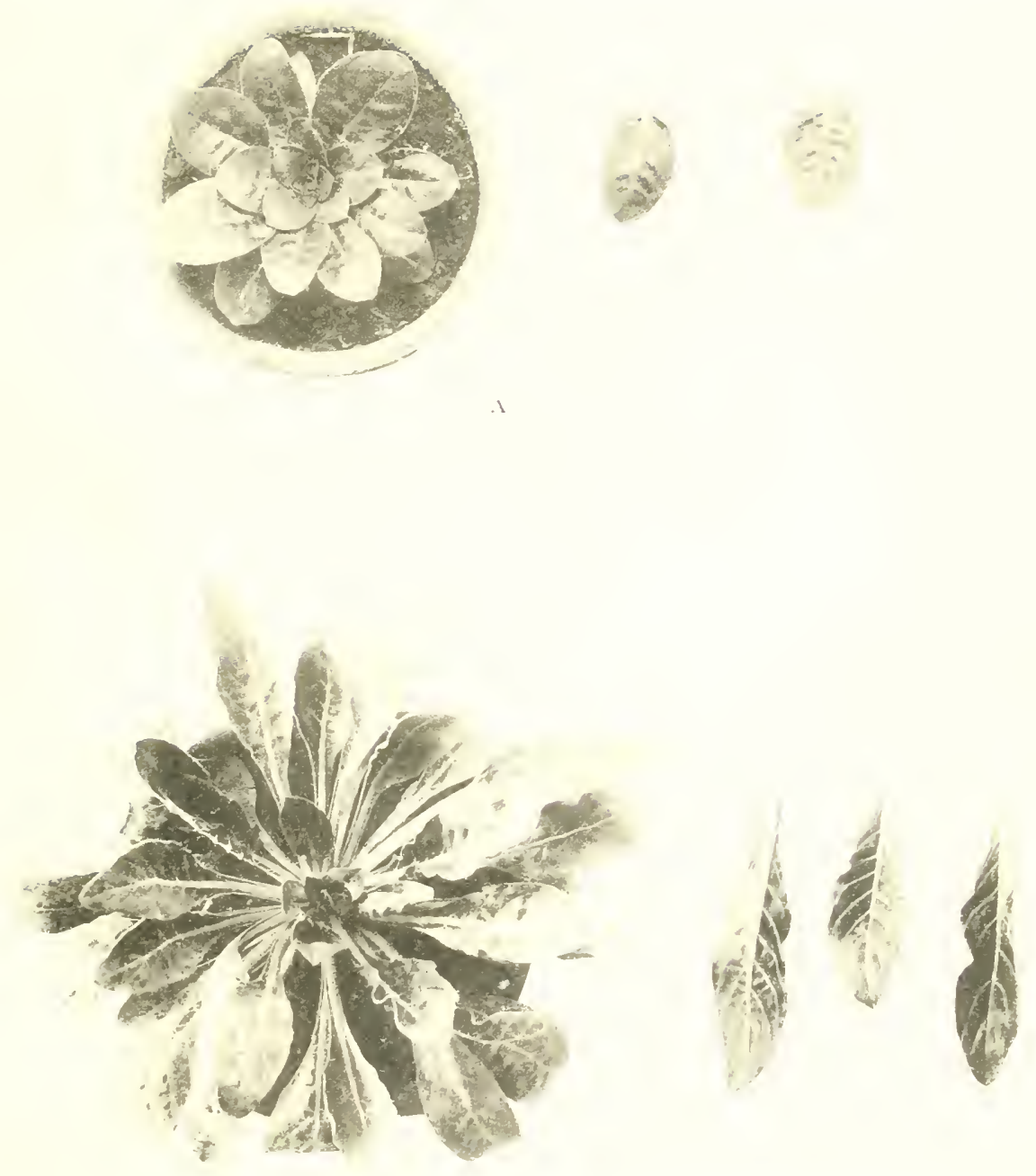

i) 

PLATE 6 .

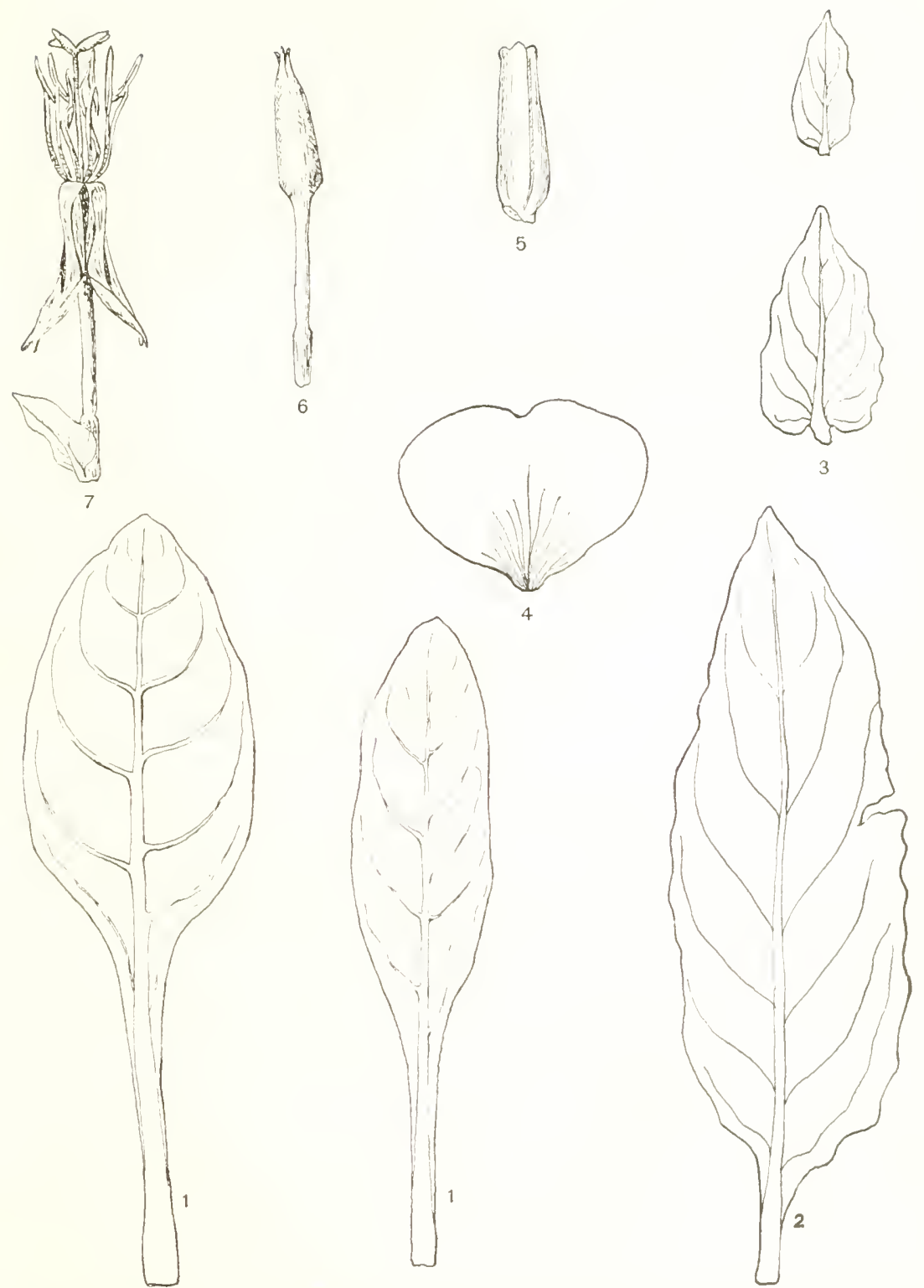

Oenuthru obhntu. 1, leaves from mature rosette; ?, stem-leaf; 3, bracts; 4, peta1; 5, cupule; 6 , bud; 7 , finver with petals removed. 


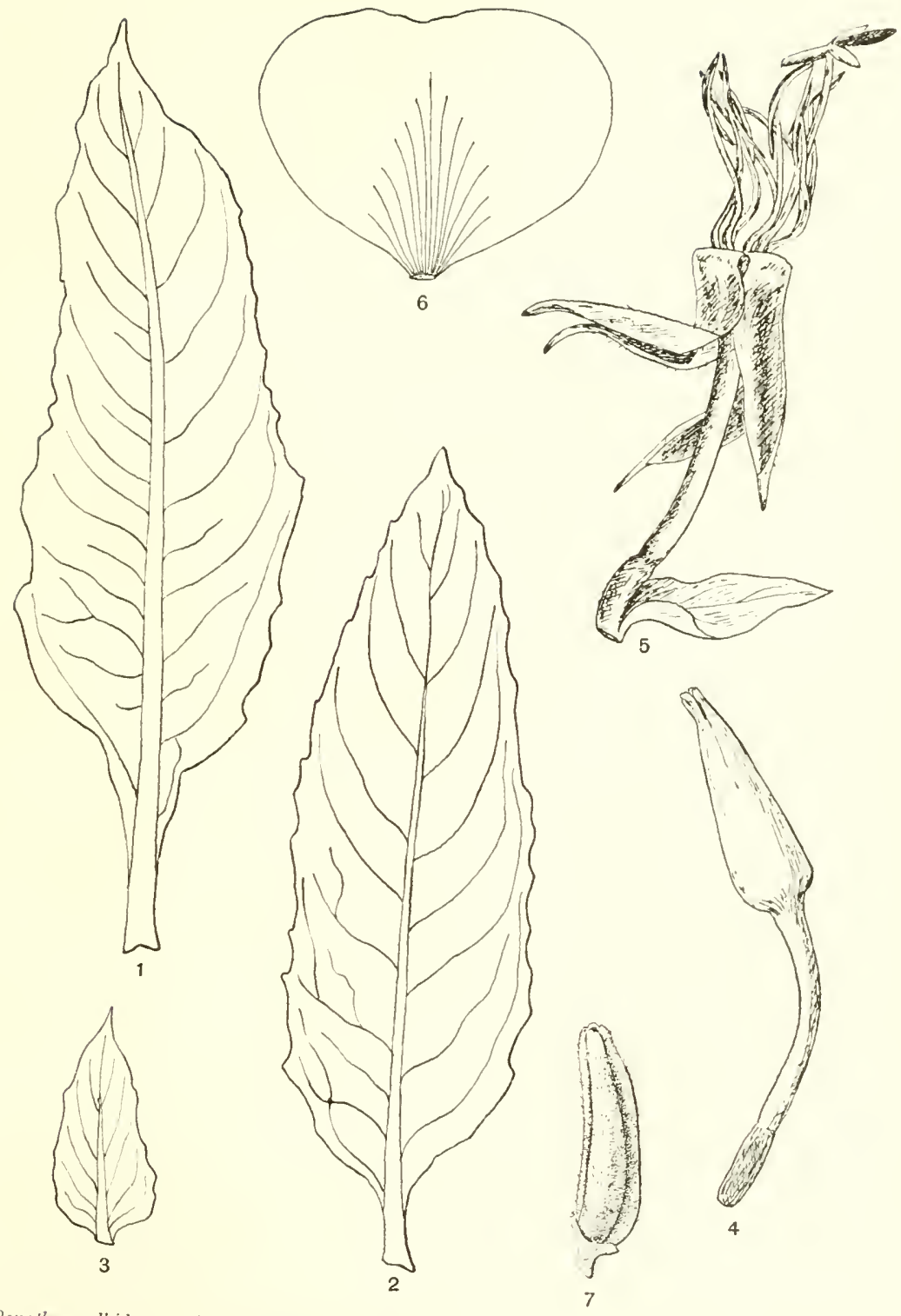

Oenothera allida. 1, leaf of mature rosette; 2, stem-leaf; 3, bract; 4, bud; 5 , flower with petals removed; 6 , petal; 7 , eapsule. 


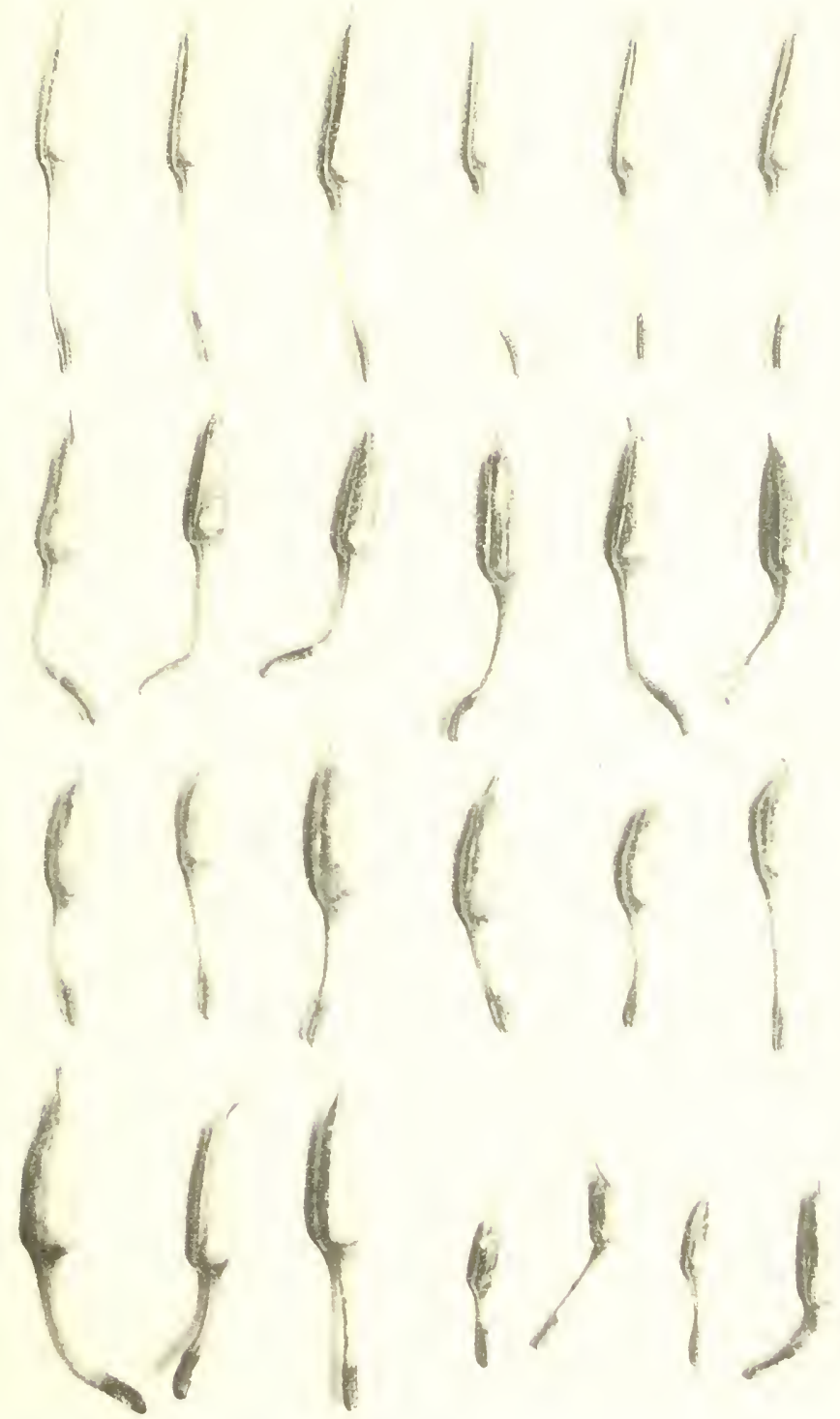



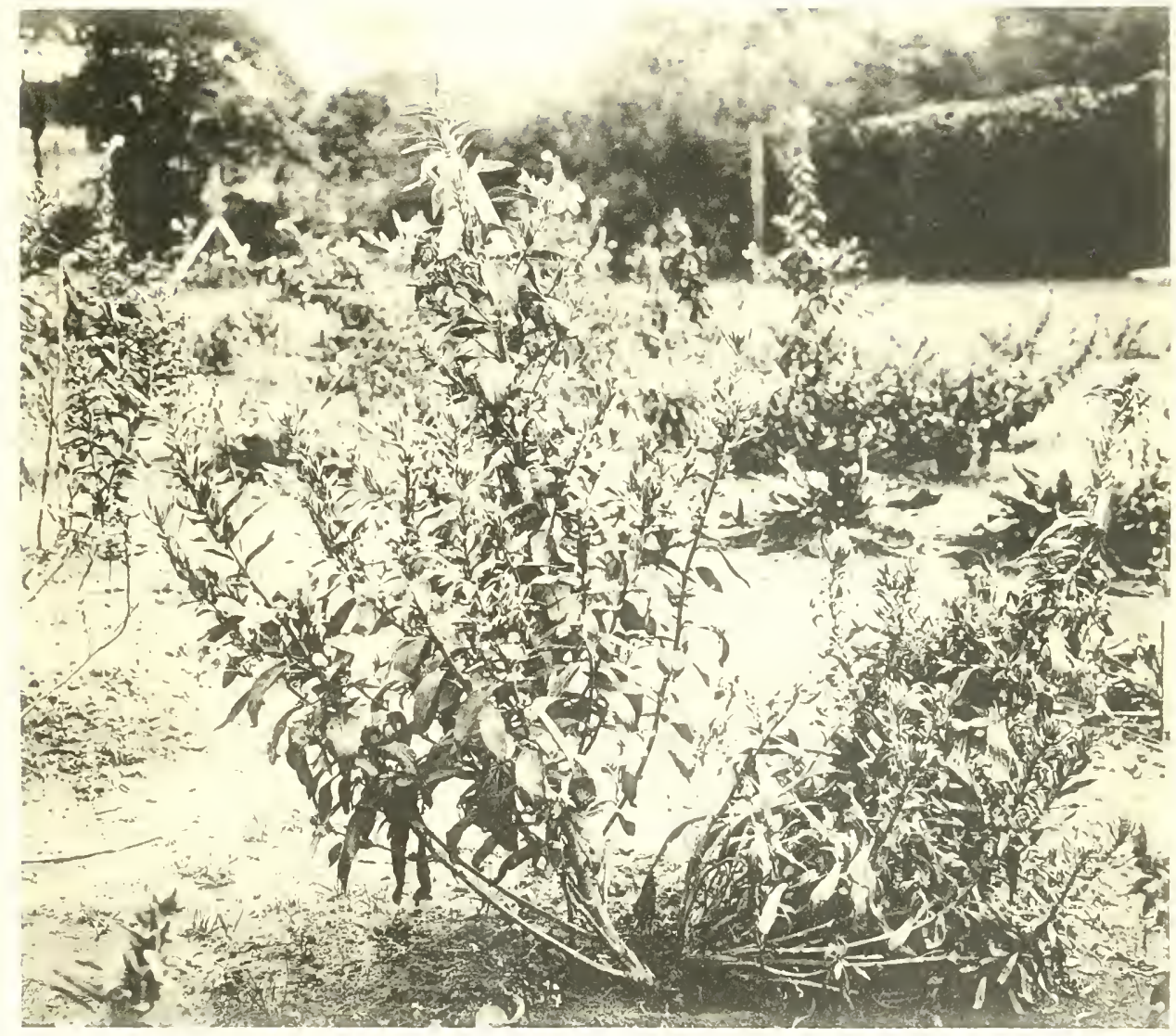





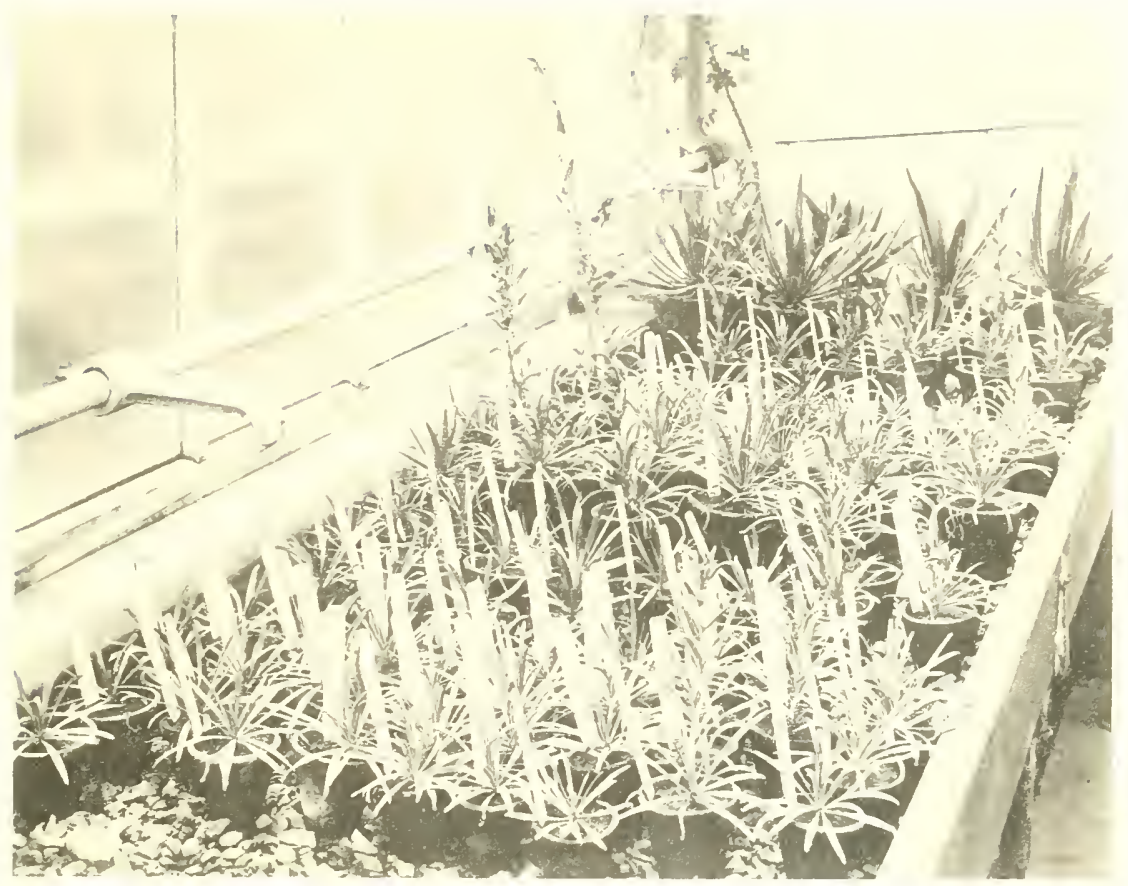

1

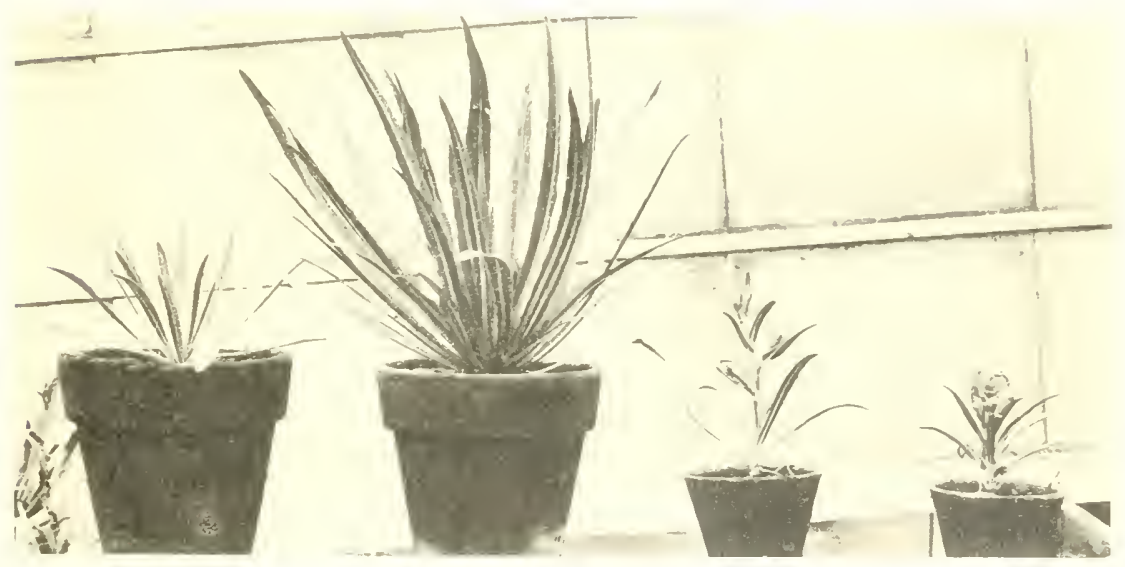





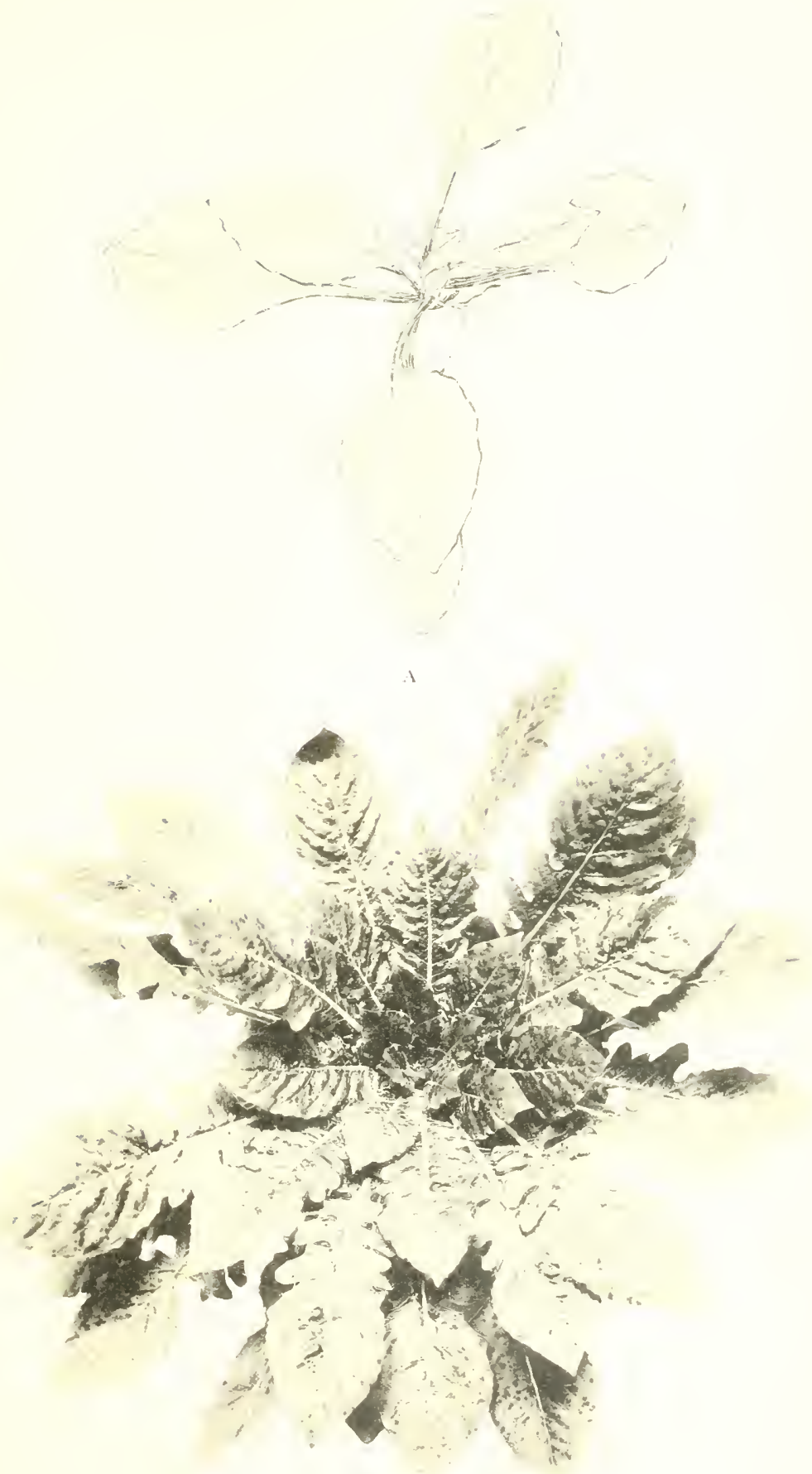

B 

PLATE 12.
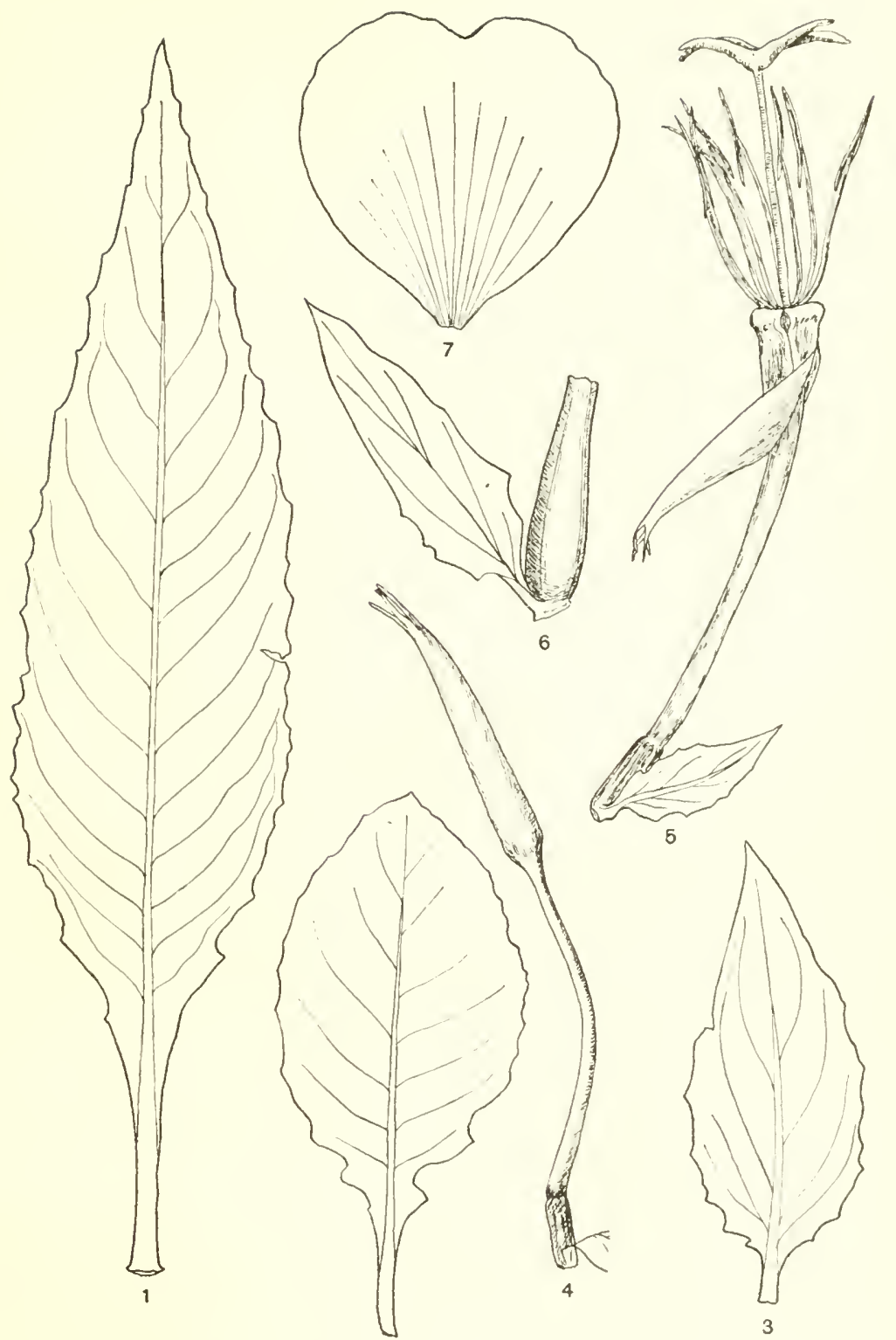

Oenothera grandiflora. 1, stem-leaf; 2 , leaf from young rosette; 3 , bract; 4 , bud: 5 , tlower with yetals removed; 6 , capsule and bract; 7 , petal (minimum size). 


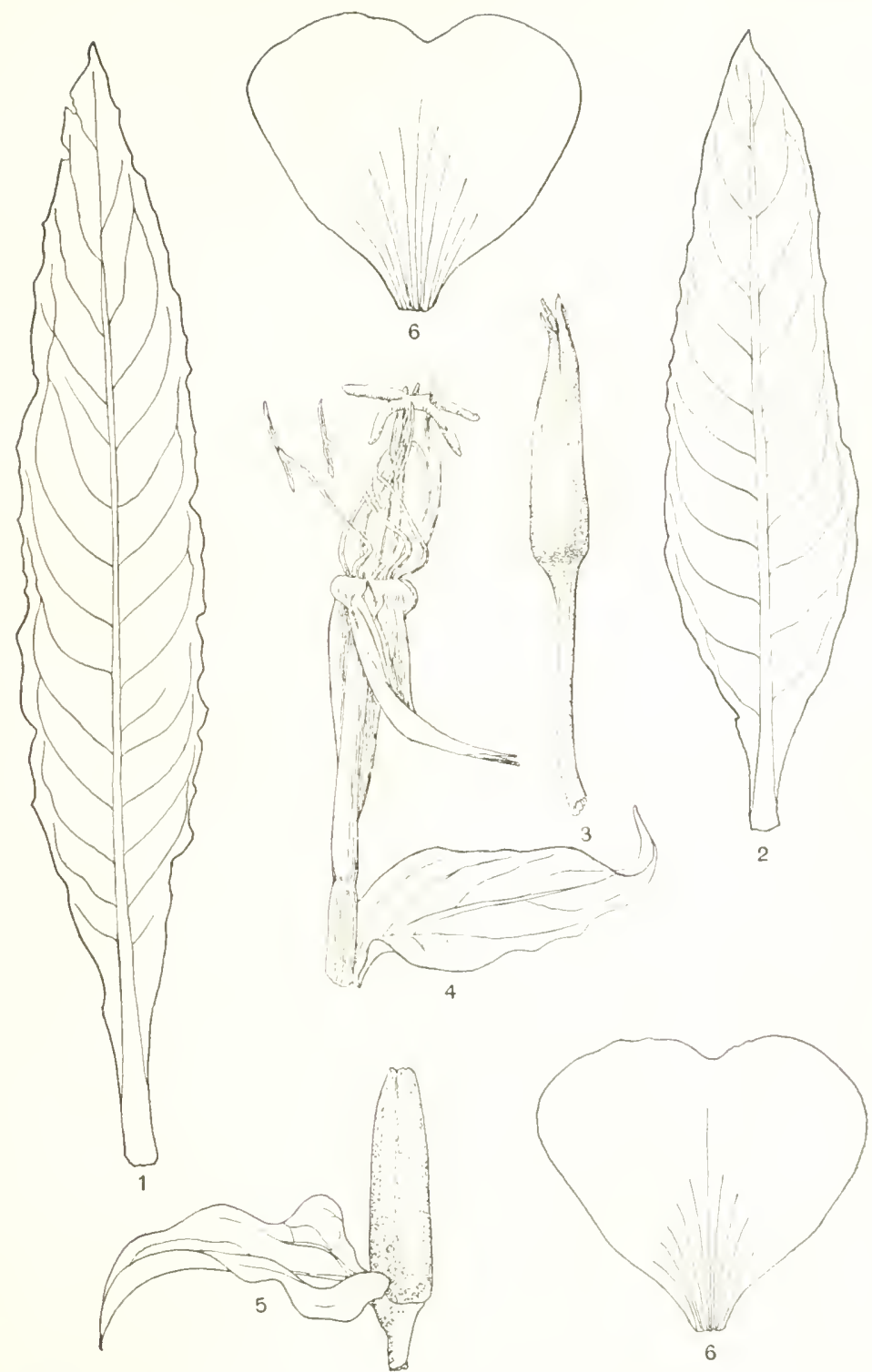

Cenothera simsiana. 1, leaf from mature rosette; 2, stem-leaf; 3, bud: 4 flower with petals removed and bract; 5 capcule and bract; 6 , petal. 



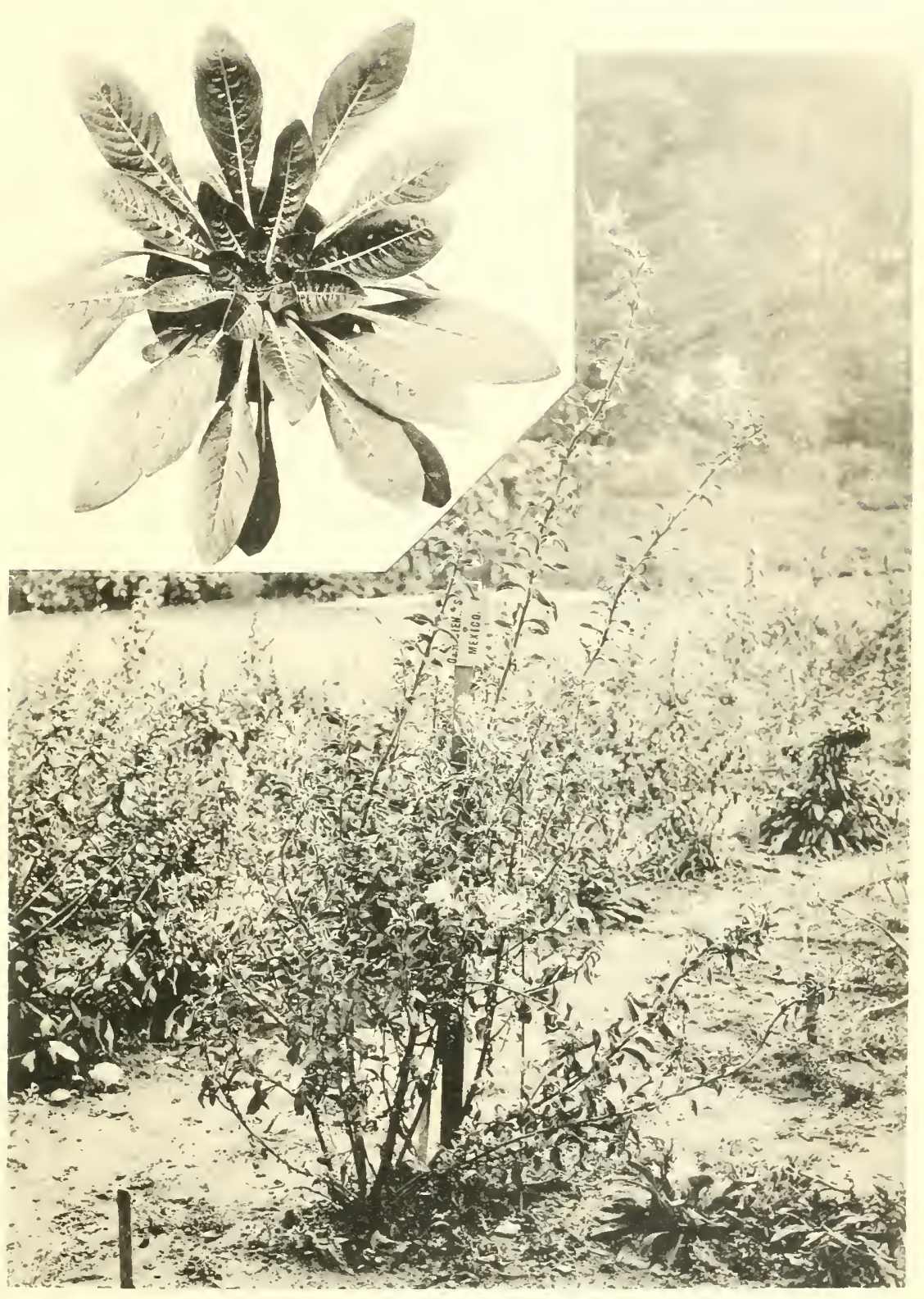





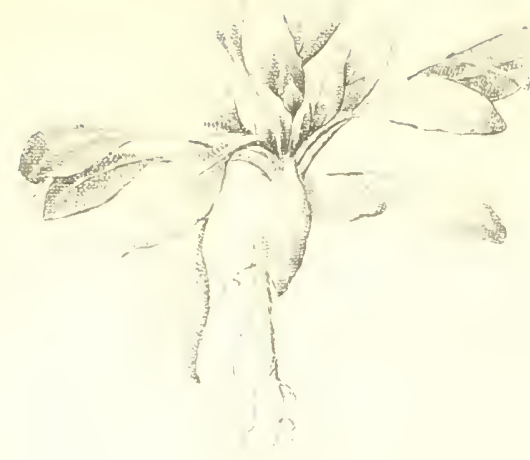

$A$

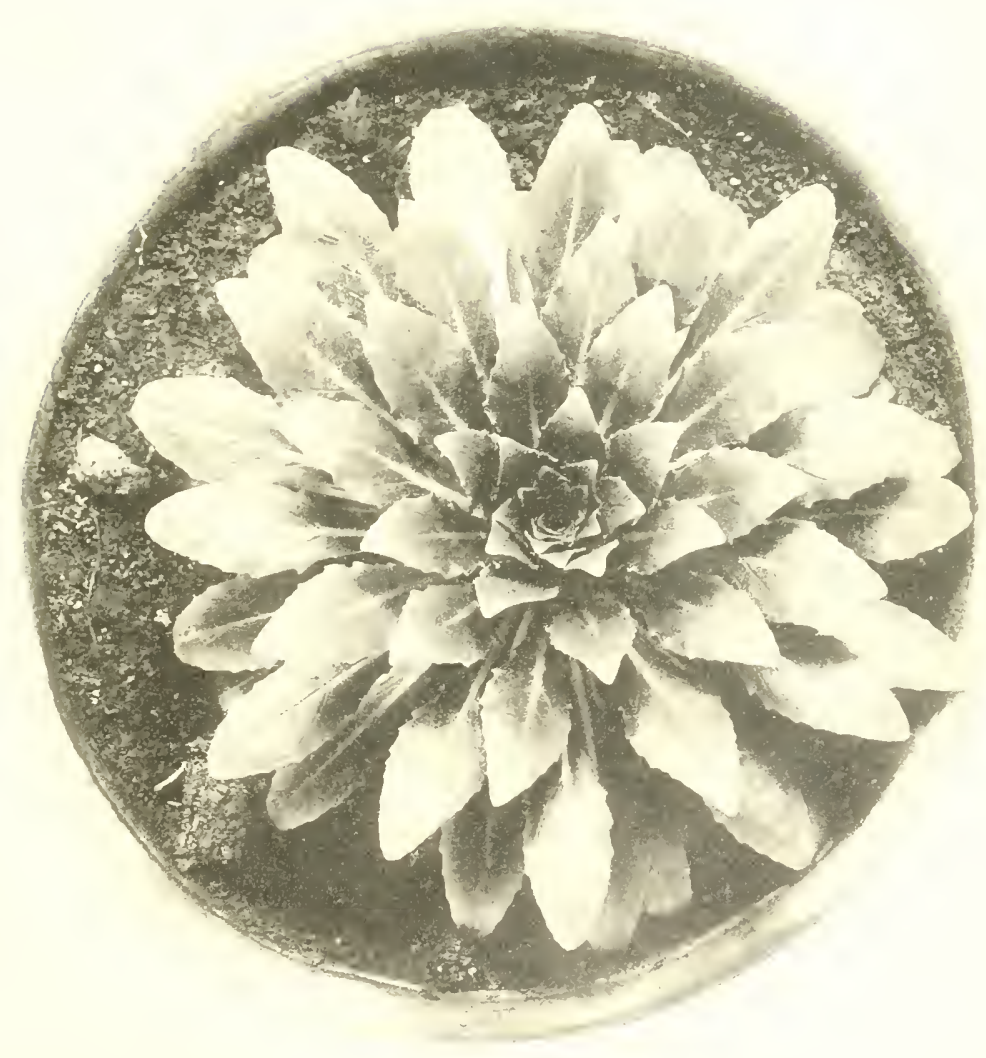

B 

PLATE 16.
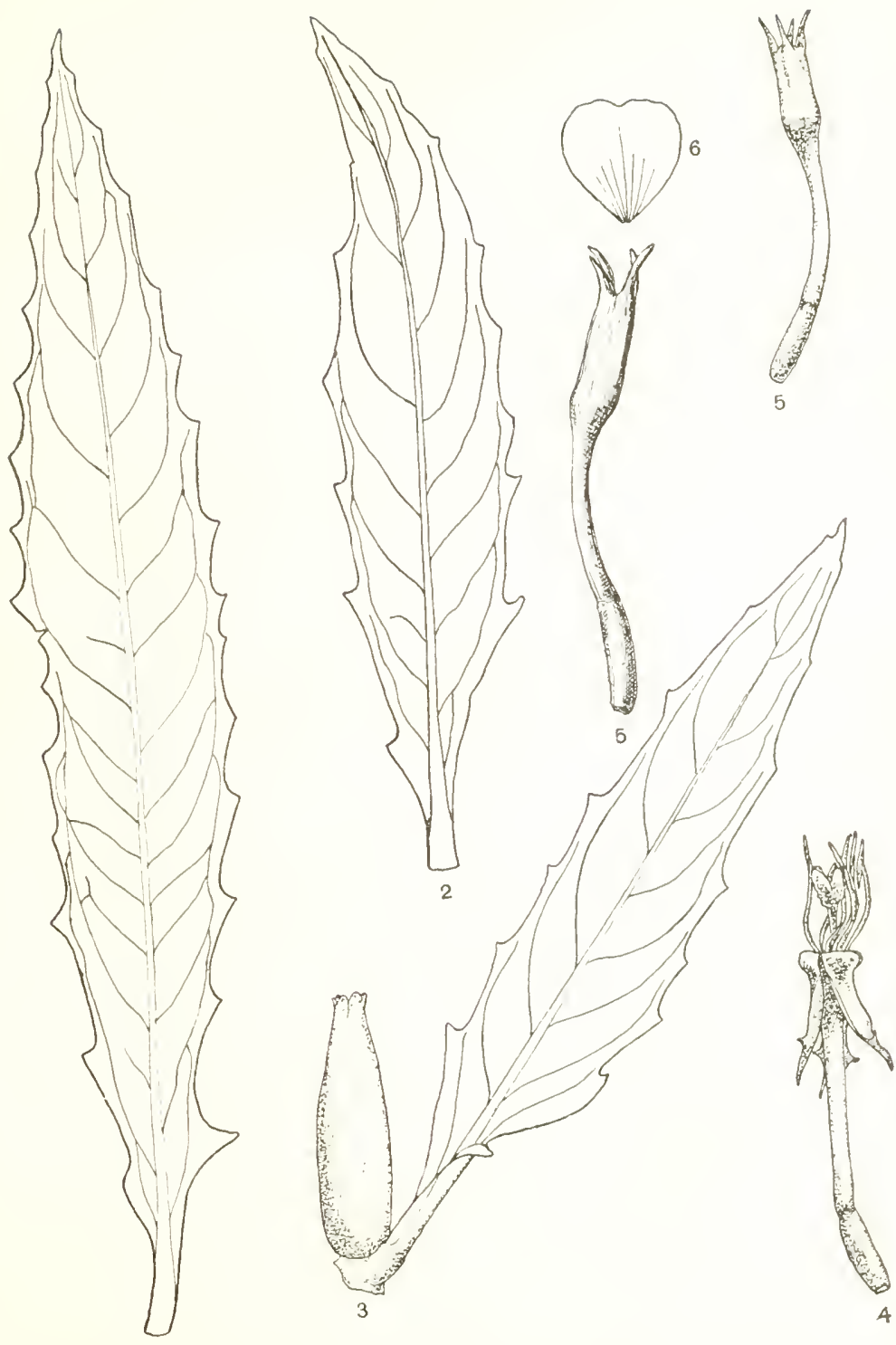

Oenothera oakesiana. 3, leaf from mature rosette; 2, stem-leaf; 3, capsule and bract 4 , flower with petals removed; 5 , buds; 6 , petal (minimum size). 



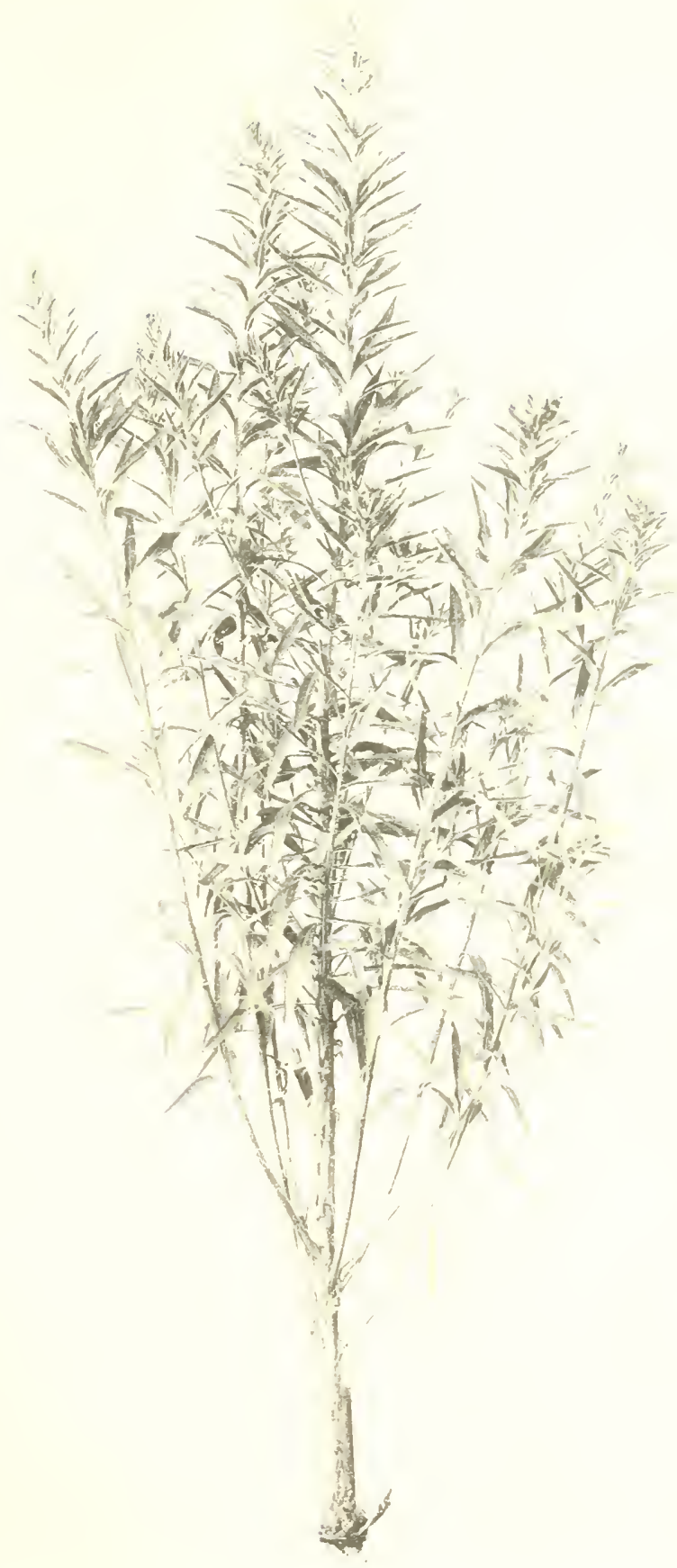





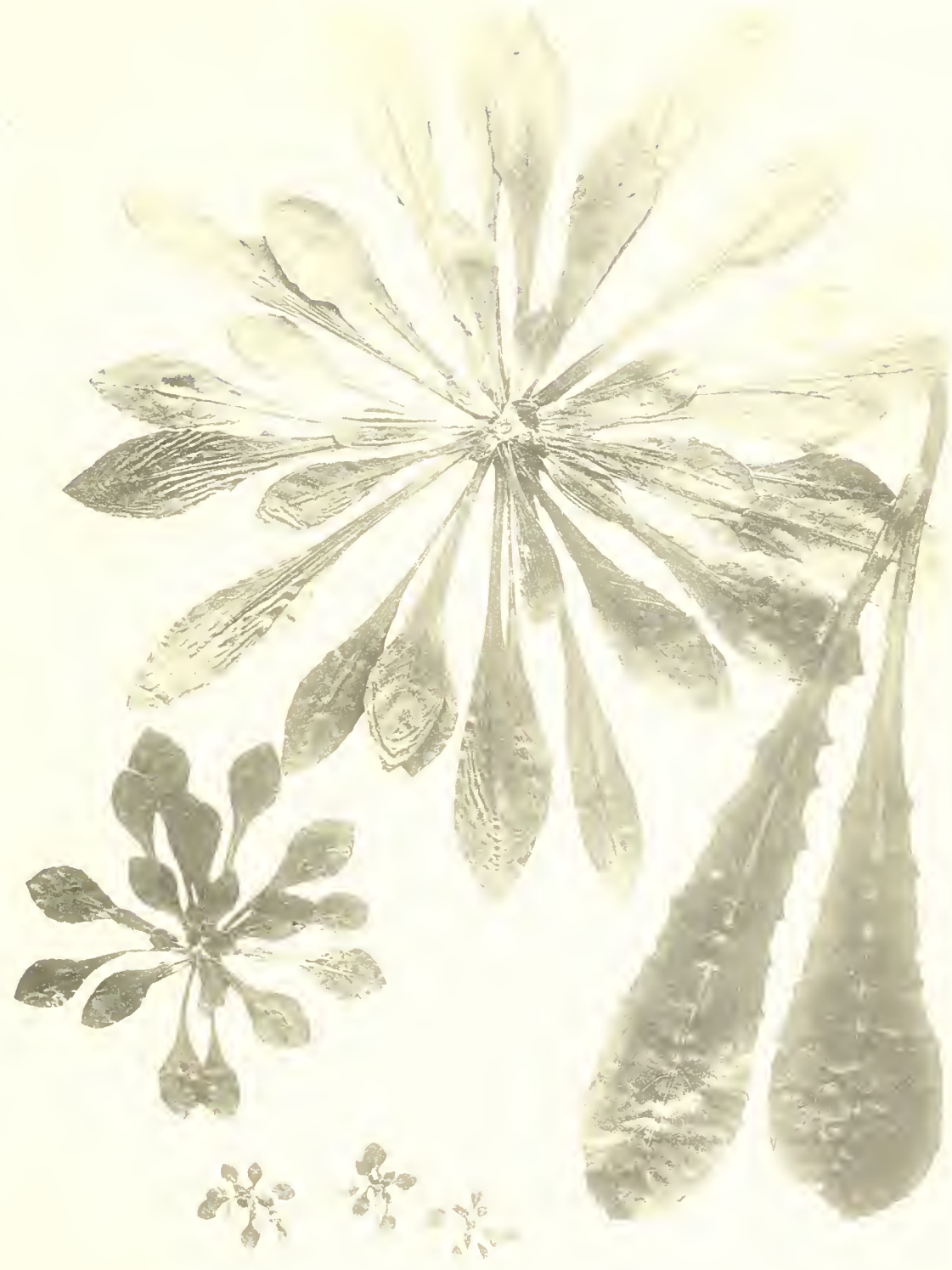





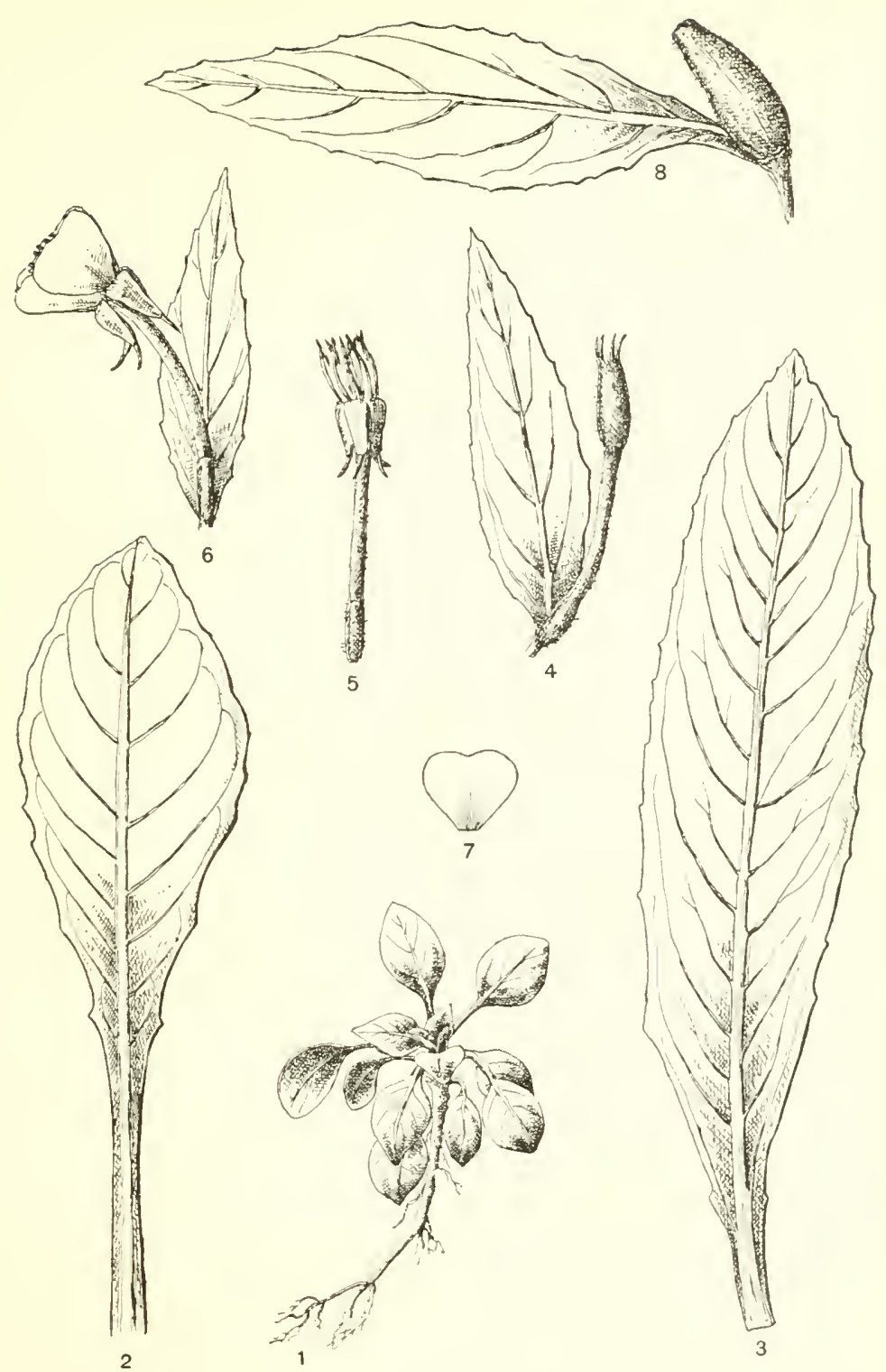

Oenothera pariffora. 1, seedling two months after germination; 2, leaf of young rosette; 3. stem-leaf; 4, bud and bract; 5, flower with petals removed; 6, flower and bract; 7 , petal: 8 , capsule and full-grown bract (from seeds from Maine). 



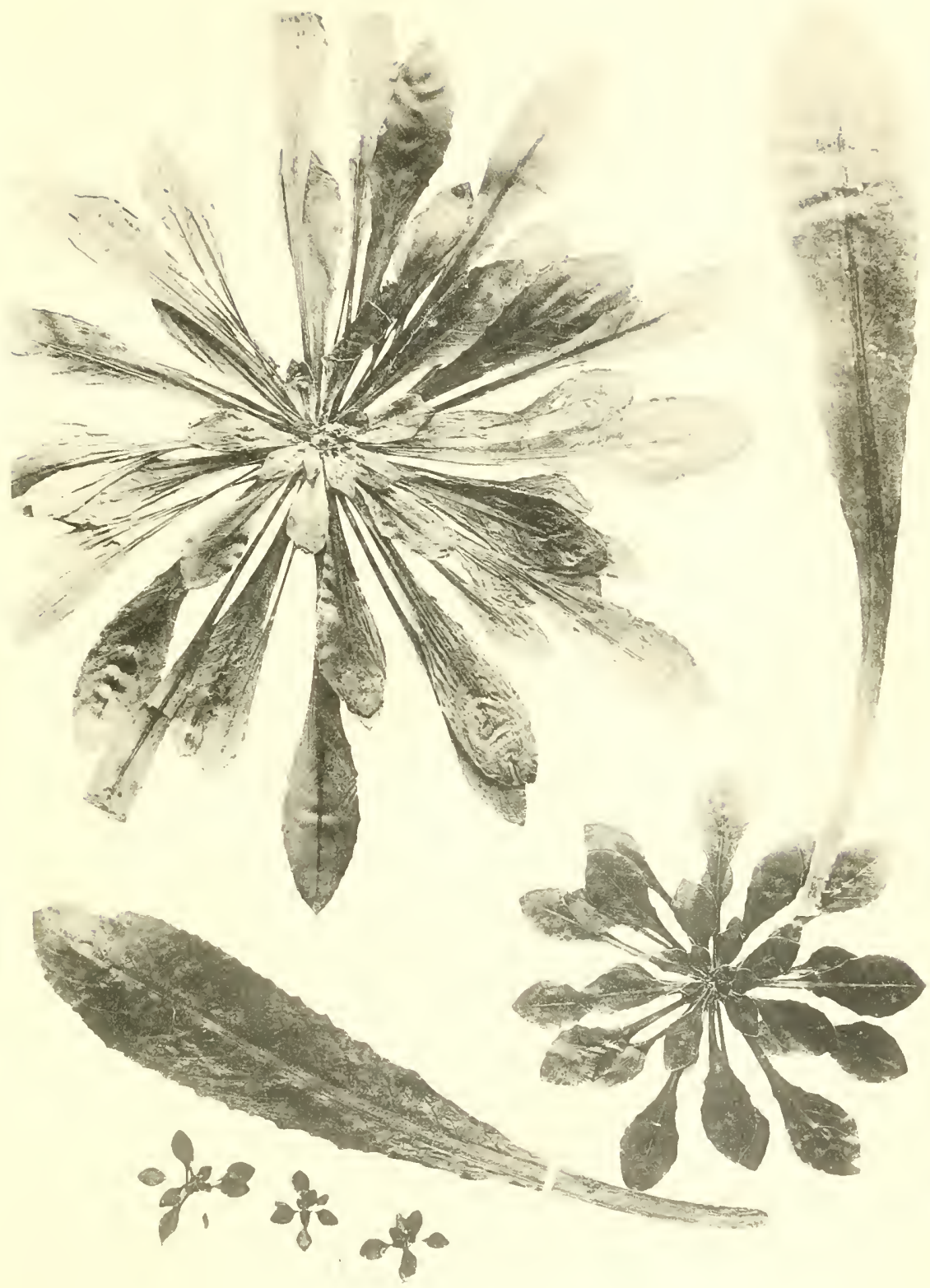







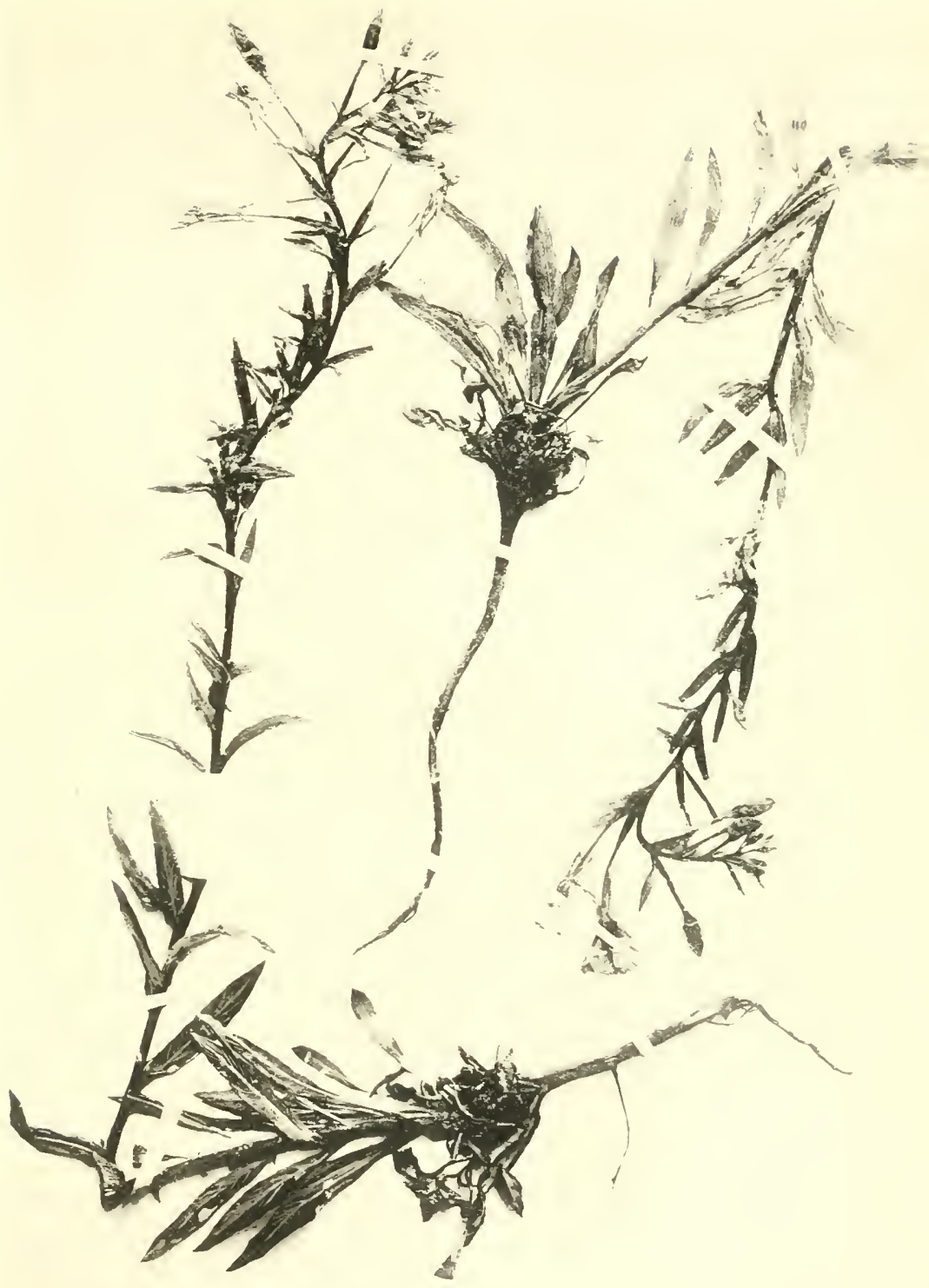




400
$42 ?$

Bioned

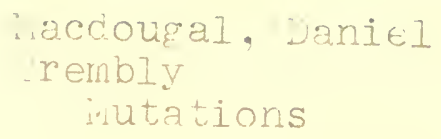

PLEASE DO NOT REMOVE CARDS OR SLIPS FROM THIS POCKET

UNIVERSITY OF TORONTO LIBRARY 
